\title{
La búsqueda del centro. Segunda parte
}

\author{
Antoni Remesar \\ CR Polis- CRIT Research Group. Universitat de Barcelona \\ aremesar@ub.edu \\ Orcid: https://orcid.org/0000-0002-1145-6279
}

\section{Resumen}

En el capítulo anterior de esta serie (Remesar 2021) analizamos cómo a lo largo del tiempo, la complejidad funcional y social que van adquiriendo las ciudades se traducen en una tendencia a la policentralidad. Si en unos momentos 'el centro' concentraba las funciones vinculadas al poder - mundano y religioso- y a la economía, desde la Baja Edad Media podemos observar una tendencia a la policentralidad marcada por la segregación del centro económico y social - en el contexto de la aparición de la burguesía comercial y de la estructura gremial de la producción- de los centros del poder religioso y/o político. Las ciudades comerciales - buena parte de ellas portuarias- segregarán el centro de comercial del centro religioso, pero dado su fuero de 'ciudades libres' este centro comercial se mantendrá unido al centro de decisiones políticas locales. La plaza central de la ciudad (ciudades del Norte de Europa e Italia) o el espacio de ribera, en el caso de ciudades portuarias como Nápoles o Lisboa, se convertirá en el 'centro' de la ciudad. 
Como veremos en esta entrega, la multiplicación de centros tomará una particular forma en el caso de Lisboa, cuando el centro político-administrativo 'del Rei' va a ubicarse en el espacio del centro económico y comercial, desgajándose del centro religioso.

Este movimiento de centros supone tanto una reorganización física de los antiguos centros - con prácticas de destrucción creadora- como una construcción de los nuevos centros, con el consiguiente desplazamiento y compartición de los elementos primarios de urbanización (Rossi 1968). En cualquier caso, en una sociedad estructuralmente religiosa, la Iglesia está presente en los nuevos centros con la construcción de monumentos, conventos, iglesias y catedrales.

Los modelos de organización de la ciudad, los modelos acerca de la forma de su trazado, provienen tanto de la época clásica-reelaborados por la Escolástica- como de las prácticas vinculadas a los distintos procesos de colonización y asentamiento que se dan en toda Europa, así como de la paulatina introducción del pensamiento Renacentista.

Palabras clave: Art Urbain, Renacimiento, Policentralidad, Roma, Lisboa

\section{Abstract}

In the previous chapter of this series (Remesar 2021) we analysed how, over time, the functional and social complexity that cities are acquiring it is translated into a trend towards polycentrality. If in some moments 'the centre' concentrated the functions linked to power - worldly and religious - and to the economy, since the Late Middle Ages we can observe a trend towards polycentrality marked by the segregation of the economic and social centre- in the context of the appearance of the commercial bourgeoisie and of the guild structure of production-from the centres of religious and/or political power. The commercial cities-many of them port cities- will segregate the commercial centre from the religious centre, but given their status as "free cities" this commercial centre will remain linked to the centre of local political decisions. The central square of the city (cities in Northern Europe and Italy) or the riverside space, in the case of port cities such as Naples or Lisbon, will become the 'centre' of the city.

As we will see in this issue, the multiplication of centres will take a particular form in the case of Lisbon, when the political-administrative centre of the King will be located in the space of the economic and commercial centre, splitting it from the religious centre for a period, but grouping this religious centre with the site of the royal power: the palace.

This movement of centres presupposes both a physical reorganization of the old ones - with practices of creative destruction - and the construction of new ones, with the consequent displacement and sharing of the primary elements of urbanization (Rossi 1968). In any case, in a structurally religious society, the Church is present in the new centres with the construction of monuments, convents, churches and cathedrals.

The organization models of the city, the models about the form of its layout, come both from the classical era-reworked by Scholasticism- and from the practices linked to the different processes of colonization and settlement that occur throughout Europe, as well as the gradual introduction of Renaissance thought.

Keywords: Art Urbain, Renaissance, Polycentrality, Rome, Lisbon 


\section{Resum}

Al capítol anterior d'aquesta sèrie (Remesar 2021) analitzem com al llarg del temps, la complexitat funcional i social que van adquirint les ciutats es tradueixen en una tendència a la policentralitat. Si en uns moments 'el centre' concentrava les funcions vinculades al poder - mundà i religiós- ia l'economia, des de la Baixa Edat Mitjana podem observar una tendència a la policentralitat marcada per la segregació del centre econòmic i social - en el context de la aparició de la burgesia comercial i de l'estructura gremial de la producció dels centres del poder religiós i/o polític. Les ciutats comercials - bona part portuàries- segregaran el centre de comercial del centre religiós, però atès el seu fur de 'ciutats lliures' aquest centre comercial es mantindrà unit al centre de decisions polítiques locals. La plaça central de la ciutat (ciutats del Nord d'Europa i Itàlia) o l'espai de ribera, en el cas de ciutats portuàries com Nàpols o Lisboa, esdevindrà el centre de la ciutat.

Com veurem en aquest Iliurament, la multiplicació de centres prendrà una particular forma en el cas de Lisboa, quan el centre politicoadministratiu 'del Rei'-no ciutadà- s'ubicarà a l'espai del centre econòmic i comercial, esqueixant-se del centre religiós .

Aquest moviment de centres suposa tant una reorganització física dels antics centres -amb pràctiques de destrucció creadora- com una construcció dels nous centres, amb el desplaçament i compartició consegüent dels elements primaris d'urbanització (Rossi 1968). En qualsevol cas, en una societat estructuralment religiosa, l'Església és present als nous centres amb la construcció de monuments, convents, esglésies i catedrals.

Els models d'organització de la ciutat, els models sobre la forma del traçat, provenen tant de l'època clàssica-reelaborats per l'Escolàstica- com de les pràctiques vinculades als diferents processos de colonització i assentament que es donen a tot Europa, així com de la gradual introducció del pensament Renaixentista referit.

Paraules clau: Art Urbain, Renaixement, Policentralitat, Roma, Lisboa

"La calle que discurre por el interior de la ciudad vendrá hermosísimamente adornada, aparte por el hecho de que debe estar absolutamente limpisima y bien pavimentada, con dos pórticos de idéntico diseño, y por casas a ambos lados alineadas y de igual altura. Pero, las partes de la propia calle en que debe aplicarse una adecuada ornamentación, son las siguientes: el puente que cruza la plaza, el lugar destinado a los espectáculos. La plaza es, en efecto, un cruce más ancho, y el lugar destinado a espectáculos no es otra cosa que una plaza rodeada de gradas'”'. (Alberti 1452, p. 349)

\section{Digresión sobre las relaciones Arte y Ciudad: 'I'Art Urbain'}

Desde el Renacimiento, 'hacer' una ciudad hermosa ha sido un tema recurrente en la teoría y práctica urbana occidental. Un tema de ida y vuelta. Podemos situar el gran tema del decoro urbano en el trasfondo de este tema. Como decía Solà-Morales, partiendo de las ideas de Vattimo (Vattimo, Gianni, 1986):

"Es necesario volver a reflexionar sobre el significado de esta palabra [ornato] y sobre el significado fundamental que tiene la noción de 'decoro' bajo del término ornato [...] Soy consciente del significado decisivo que tiene este término en el pensamiento de León Batista Alberti, y, en general, en la 
estética del humanismo. [....] condición decorativa del arte y la arquitectura contemporánea, no en el sentido de vulgaridad, trivialidad, repetición de estereotipos establecidos, sino como una discreto replegamiento de una función posiblemente secundaria, a una función que sobrevuela el hipotético fondo de las cosas "(Solà-Morales1995, p. 79)

Los tratadistas del Renacimiento establecen las ideas clave para un entorno urbano bellamente organizado. Trama ordenada y decoro. La 'Concinnitas"' de Alberti indica una particular atención a la forma y al orden, a la armonía y el ritmo. En parte estas ideas estaban fundamentadas en Vitruvio, pero sobre todo en los nuevos dispositivos de estudio del mundo y de su representación, especialmente la 'perspectiva' como un medio de representar la realidad y como una forma de abordar la arquitectura y la forma del hábitat humano. Estas ideas, de Alberti, Palladio y muchos otros, se difundieron en Europa gracias a la imprenta. Una idealización de las ciudades resultante tanto de una nueva lectura de la arquitectura clásica y de los textos de Vitruvio, o, como vimos en la primera parte, de una racionalización de modelos medievales como las bastidas francesas (Rossi 1968) o las ciudades catalanas y aragonesas en la expansión al sur de la Península (Morris 1979)

Esta idealización racional se reflejaría primero en modelos pictóricos creados a partir de los nuevos métodos de representación para pasar, luego, a la construcción de algunas ciudades siguiendo estos preceptos, como se haría en la planificación de la nueva Ferrara - la Addizione Erculea proyectada por Biaggio Rossetti a finales del siglo XV, que Zevi (Zevi 2006) la considera la primera ciudad moderna de Europa; a algunas ampliaciones extramuros como fue el caso, desde 1513, del Bairro Alto de Lisboa (Carita 1994, 1999); y, ya a finales del siglo XVI, en algunas operaciones de rehabilitación dentro de las ciudades amuralladas, como sería el caso de la Roma de Paulo III (Benévolo, 1975; Giedion, 1941) o en la construcción de nuevas 'ciudades ideales', como Palmanova (1593) en el norte de Italia siguiendo los principios de Serlio.

Todas estas ideas abrieron un espacio para la 'venustas' de Vitruvio y para una corriente de pensamiento sobre el papel del arte en la composición y creación de la forma de la urbana. Lo que en francés se llama "Art Urbain" que según Choay

"Esta expresión, consagrada por H. Lavedan designa la construcción o la ordenación del territorio de las ciudades como se teorizó desde el Quatrocento, y luego se puso en práctica gradualmente durante el Renacimiento, el Barroco y el período Neoclásico.Para el arquitecto-artista, 'Art Urbain' se diferencia de los procedimientos y arreglos medievales por su carácter teórico y globalizador, así como por su finalidad estética. La preponderancia que se da a

1 Concinnitas es un término usado para indicar una particular atención a la forma y al orden armonizando elementos humanos con reglas naturales matemáticas, armónicas o rítmicas. Se utiliza en arquitectura (Alberti) o en literatura. Como figura retórica la concinnitas ha evolucionado en cuanto a su significado: en el mundo latino significaba elegancia y posteriormente refinamiento. En el Renacimiento indica armonía. 
la dimensión estética también se diferencia del urbanismo porque, además, no tiene pretensión científica. El concepto de 'Art Urbain' introdujo la proporción, la regularidad, la simetría, la perspectiva en las ciudades occidentales, aplicándolas a las calles, plazas, edificios, al tratamiento de sus relaciones y sus elementos de conexión (arcadas, columnatas, puertas monumentales, arcos, jardines, obeliscos, fuentes, estatuas, etc.). Al 'Art Urbain' le debemos la noción de composición urbana, derivada de la pintura.... Algunos arquitectos intentan hoy reintroducir esta noción para darle al urbanismo una dimensión estética, de la cual Camillo Sitte fue el primero en teorizar la deficiencia" (Choay 1998)

El término francés "urbanisme" que emplea Choay o el castellano "urbanismo" debe ser entendido como al equivalente al inglés como 'Town-Planning', dado que el término inglés 'urbanism' tiene otro significado. En inglés hay una tradición del uso de esta acepción que tiene su origen en un artículo de Wirth donde plantea:

"Una definición sociológicamente significativa de la ciudad busca seleccionar aquellos elementos del urbanismo que la marcan como un modo distintivo de grupo humano de vida (...) Mientras identifiquemos el urbanismo con la entidad física de la ciudad, viéndolo simplemente como delimitado rígidamente en el espacio, y procedamos como si los atributos urbanos dejaran de manifestarse abruptamente más allá de una línea divisoria arbitraria, no es probable que lleguemos a cualquier concepción adecuada del urbanismo como modo de vida "(Wirth, Louis, 1938).

Esta utilización del concepto de urbanismo, permite entender el oxímoron que, para los formados en la tradición de la "ville-urbs" [dimensión física, formal, del hábitat], representa el término "Tactical Urbanism²". En su acepción de town planning, el urbanismo no puede ser táctico, es axiomáticamente estratégico. Sin embargo, entendido como 'way of life', que se acercaría al concepto de "civitas"(Capel 2002, 2003), puede conceptualizarse perfectamente una dimensión táctica como la que está presente en las propuestas de Certeau (Certeau 1990; Certeau et al 1999)

En 1965, Choay introduce la distinción entre "urbanismo progresista" y "urbanismo culturalista", lo que podría hacernos pensar que la corriente del 'Art Urbain' se decantaría en el platillo de la balanza del "urbanismo culturalista". Las propuestas urbanas de Sitte, Howard o Unwin, con la derivación al movimiento de las "GardenCities" junto al movimiento francófilo del 'Art Public' -origen del urbanismo francés internacionalista con nombres como Forestier, Agache o Jaussely (Monclús 2015; Remesar 2016)- o del 'Civic Art' (Hegeman\& Peets 1922; Robinson 1904; Bohl \& Lejeuen 2009) por no hablar del movimiento City Beatiful ( Blumber 2019; Wilson 1989) o de la eclosión de los distintos "Art Noveau" hasta llegar al que podemos Ilamar neo-art urbain o al "New Urbanism" (Risebero 1986;1992) de la últimas décadas, son algunas de las corrientes que encajarían en la idea del "urbanismo culturalista". Sin

2 Tal y como podemos leer en los trabajos de Carmichael 2020; Lydon (ed), 2012, 2015; Olivier, Greer et al., 2020, o en la últimas propuestas de acción en la ciudad de organismos multilaterales como UNHabitat, el BID (Banco Iberoamericano de Desarrollo) e incluso el FMI (Fondo Monetario Internacional) 


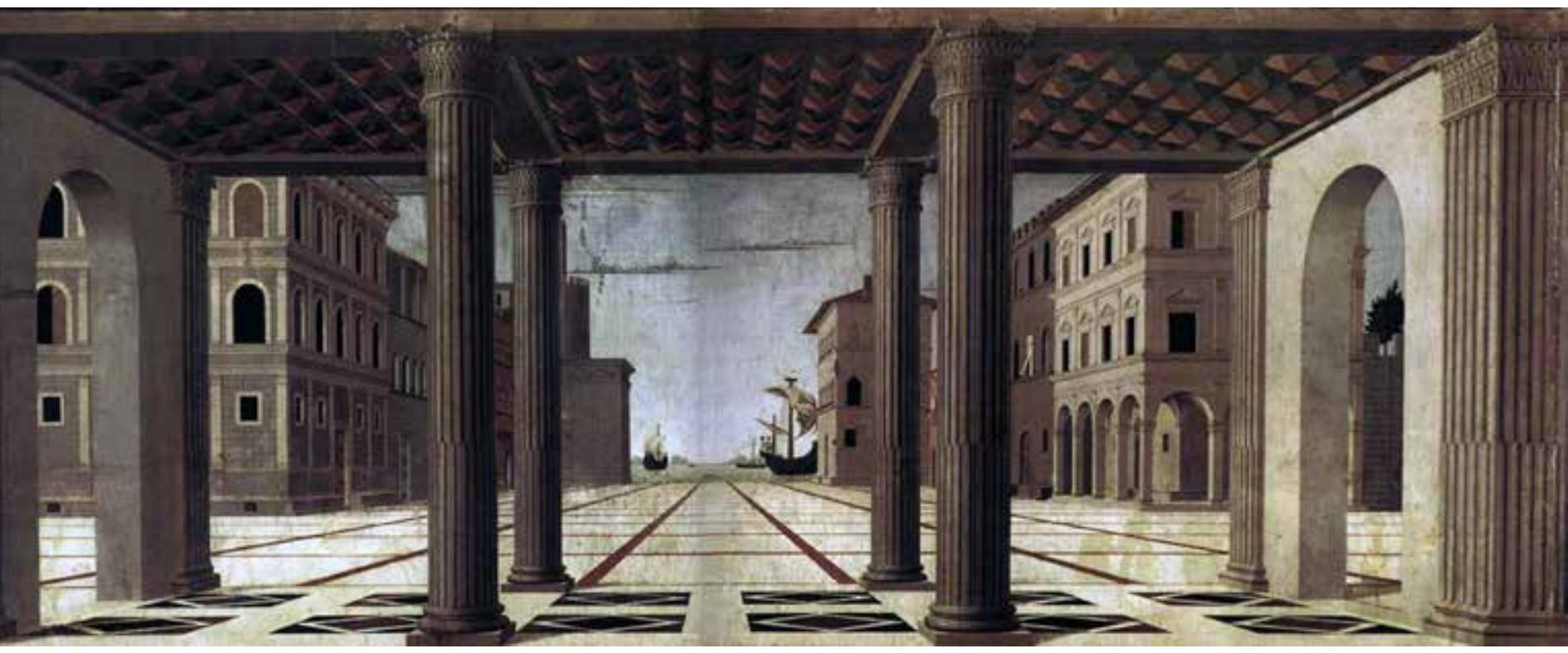

Laciudadidealllamada “deBerlín”, sinatribución,ca.1477(StaatlicheMuseen Berlin,GemäldegalerieBerlín).

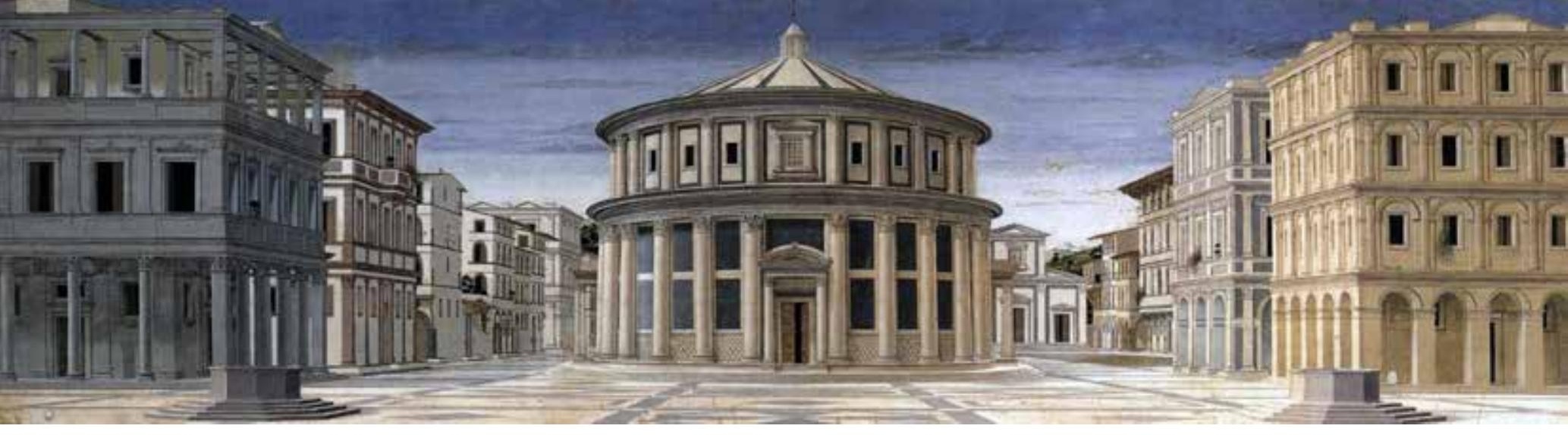

La ciudad ideal llamada "de Urbino", atribuida a algunos de los pintores de la corte de Federico de Montefeltro (Piero della Francesca, Melozzo da Forlì, Luciano Laurana o Francesco di Giorgio Martini), oa los del círculo florentino de Lorenzo el Magnífico ( Giuliano de Sangallo o a su taller, Botticelli o Leon Battista Alberti-en este caso, sería su única obra pictórica-), ca. 1480-1490 (Gallería Nazionale delle Marche, Urbino).

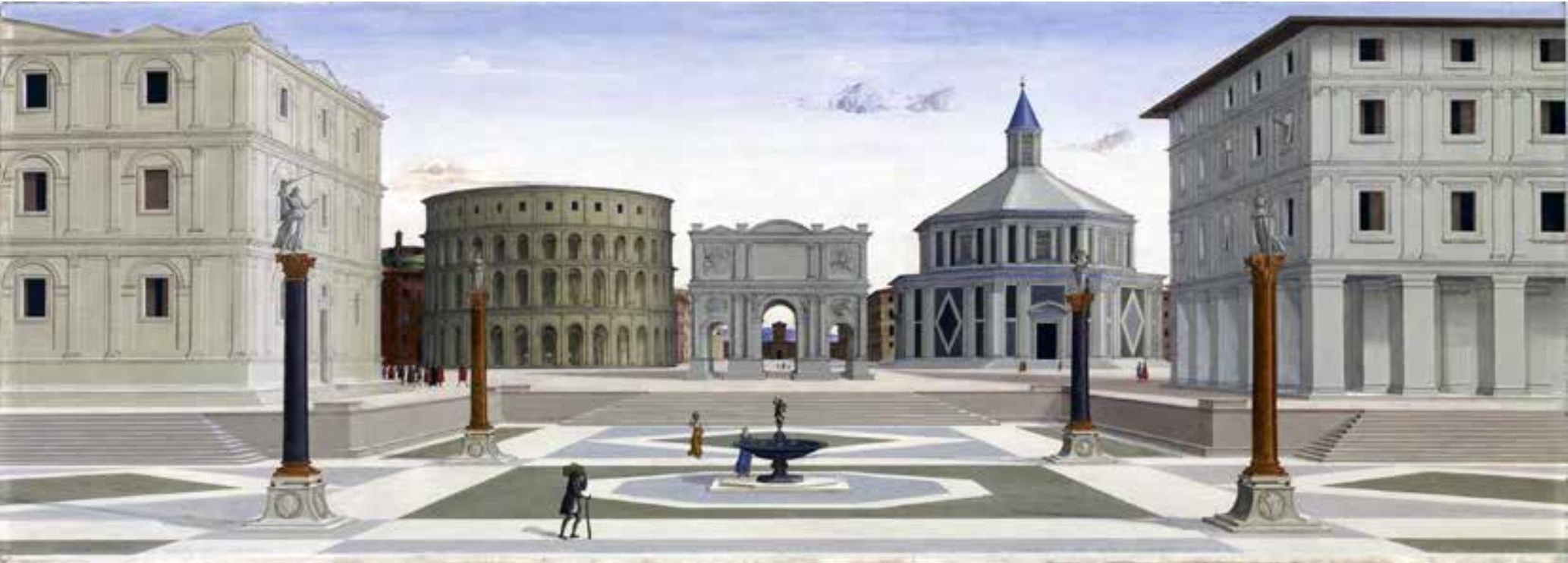

La ciudad ideal llamada "de Baltimore", atribuida a Fra Carnevale, ca. 1480-1484 (Walters Art Museum, Baltimore). 
embargo, la visión del conjunto de estas corrientes respecto al papel del arte ni es homogéneo ni responde a los mismos objetivos y finalidades. Lo reconoce la propia Choay en relación a las realizaciones del 'Art Urbain ${ }^{3 \prime}$. En el primer artículo de esta serie (Remesar 2021) siguiendo la propuesta de Plattus (2009) comprobamos que algunos principios del 'Art Urbain' se mantienen vivos en la actualidad en el marco de tendencias que nunca entenderíamos como pertenecientes a esta tradición. Tal y como señala Monclús, el 'Art Urbain' de principios del siglo XX-enmarcado en las corrientes del 'Art Public' franco belga, del 'Civic Design' Inglés, del 'Civic Art' germano y norteamericano-

"tiene profundas raíces en una serie de fenómenos muy diversos que van desde el movimiento Arts and Crafts al preservacionismo, desde la tradición pintoresquista al tratamiento clasicista de los centros urbanos. Movimientos que, a veces, resultan ciertamente contradictorios en las preferencias formales: neomedievalismo pintoresquista, composiciones beaux-art, eclecticismo urbanístico. Pero que surgen de una voluntad implícita o explícita de convertir la ciudad en una obra de arte" (Monclus 1995).

Indica Monclús, lo vimos ya en la primera parte, dos tendencias, una asociada más a la idea del «arte en la ciudad ${ }^{4} »$, la otra a la idea de «arte de construir la ciudad», en la que la dimensión estética y artística tienen relevancia.

Desde mi punto de vista, la diferencia planteada por Choay entre los dos tipos de urbanismo, y en su consideración sobre las relaciones entre Arte y Ciudad, sería válida en el terreno ideológico y de los posicionamientos teóricos, pero no cubriría, pertinentemente, las actuaciones derivadas en su activación práctica. Nos preguntamos, ¿cuáles son las dimensiones prácticas a las que se refiere el concepto de 'Art Urbain' enunciado por Choay?

El concepto de 'Art Urbain' abarcaría dos grandes líneas de trabajo. Una basada en procedimientos de "control figurativo del espacio" (Sabaté 1999) en buena medida derivados de aquellos intentos de crear "normas urbanas" ya en la Baja Edad Media, sumados a los iniciales procedimientos de representación pictórica y que crisolarán en el desarrollo de reglamentos u ordenanzas urbanas. Como señala Sabaté, habitualmente la ordenanza acaba regulando a la defensiva en relación al volumen

3 "Atestiguan una gran diversidad en su naturaleza y escala que van desde operaciones de embellecimiento estructural o fragmentario, hasta extensiones extramuros de ciudades medievales o creaciones ex nihilo, la mayoría de las veces vinculadas a residencias principescas" (Choay 1988)

4 Es curioso constatar como este doble enfoque - el objeto artístico aislado, o el objeto artístico en el contexto urbano - sobre el papel del arte en la ciudad se reproduce en la actualidad con el concepto de "Arte en el Espacio Público" o "Public Art" en la acepción que nosotros utilizamos (Remesar 2019) . Como señalaba Choay en 1988 : "Hoy, a diferencia del arte urbano, el urbanismo no ha incluido el arte entre sus objetivos fundamentales. El campo de las grandes artes se divide en una multiplicidad de corrientes y la arquitectura tiende a seguir modos formales, dictados por pequeños grupos profesionales. Además, el arte ha perdido su condición de valor colectivo. La pintura y la escultura en sus formas tradicionales han entrado en circuitos esencialmente privados (transmitidos por los museos), y la investigación del arte para uso público sigue siendo limitada (murales, land art) y, a menudo, condicionada por los media (eventos)." 
edificado, para el que se marcan unos límites máximos de alturas y ocupación. Estas ordenanzas fijan, también, unos mínimos requisitos de habitabilidad para garantizar una ventilación e iluminación adecuadas. Sin embargo cabe resaltar que las ordenanzas lo son de 'policía urbana' y por ello pretenden actuar tanto en la 'ville' -trazados, construcción, materiales, normas de decoro urbano, procedimientos administrativos de tramitación, el tratamiento de las fachadas, la relación entre los edificado y la calle - como en la 'cité' al fijar normas en relación a la higiene, en lo relativo a la convivencia y las actividades, en lo tocante a la seguridad ciudadana. Parece que el objetivo es conseguir una ciudad armónica y regular que facilite la convivencia con la idea subyacente de que cuanto mejor sea la regulación del entorno físico, mejores comportamientos obtendremos de la ciudadanía, por ello un énfasis de estas Normas en los elementos primarios de la construcción de la ciudad: el trazado y la monumentalización (Rossi 1968). Conseguir unas ciudades hermosas que superen las dificultades de circulación e higiene de los trazados medievales y tardo medievales, es una larga aspiración de aquellos que reflexionan y piensan sobre el hecho urbano.

\section{Renovar la ciudad con nuevos criterios}

Destrucción creadora: regularidad, geometría y perspectiva. Renovar la ciudad

"Hay otro tipo de trabajo, que se llama Alemán (Gótico), el cual es de ornamentación y proporción muy diferentes de los antiguos y los modernos; hoy no se emplea por los excelentes, que huyen de ello como monstruoso y bárbaro, olvidando la armonía en las cosas, que más es confusión o desorden, así puede llamarse; haciéndolo en sus edificios, que son muchos y que han corrompido el mundo, con las puertas adornadas de columnas sutiles y torcidas a manera de vides, que no pueden tener fuerza para resistir el peso con esa ligereza; y cosas por todas las caras y además con ornamentos, y hacían los malditos tabernáculos unos sobre otros, con tantas pirámides y puntas y hojas, que parece imposible que ello pueda resistir; y que parecen hechas de papel, que de piedra o mármol. Y en estos edificios hacían tantos relieves, rupturas, repisas y volutas, que desproporcionaban todas las obras que hacian, y a menudo de tantas cosas puestas, iban a tanta altura que el final de una puerta les tocaba el techo. Esta manera la inventaron los Godos, que por tener arruinados los edificios antiguos y muertos los arquitectos por las guerras, lo hicieron después, que construyendo de esta manera, volvieron a los techos en ángulo agudo y llenaron toda Italia de estos malditos edificios, que ya no se quieren hacer más, sin proporciones ni método en ellas. Quiera Dios que escape cada país en caer en tal pensamiento y trate los trabajos, que no poseen belleza y si mucha deformidad, y no merecen que se los miente en más que esto." (Vasari 1550, Introducción cap III)

Tendemos a considerar en periodo del Renacimiento desde una óptica idealizada y magnificada por los logros artísticos y arquitectónicos. Además, englobamos en un solo espacio cognitivo focalizado en el Norte de Italia, prácticas culturales, sociales y económicas que abarcan, unas veces los siglos XV y XVI, y otras los siglos XIV a XVI, 
superponiéndose a los momentos álgidos de la Baja Edad Media (Panofsky, 1960). La delimitación temporal y espacial no están claras, a lo que se suma el hecho de que sus transformaciones ocurren en diversos centros artísticos y culturales. Este periodo es el de consolidación del capitalismo comercial de los grandes mercaderes ${ }^{5}$; el de la unificación de los Estados Nacionales que lleva a la desaparición del régimen feudal. Un periodo de innovaciones, en las artes (Burke, 1986), en las ciencias, en la navegación que abren la época de los 'descubrimientos' ultramarinos y de colonización de nuevas tierras, en buena medida determinado por la caída de Constantinopla en manos de los turcos (1453) y que cierra las rutas comerciales del Mediterráneo con Extremo Oriente obligando a buscar otras nuevas en el Atlántico a la búsqueda de las preciadas especias.

Pero es, también, una etapa convulsa en las relaciones entre lo divino y lo profano. En 1521, el papa León X, publica la excomunión de Martín Lutero y en este mismo año Carlos $V$, mediante el decreto de Worms lo declara prófugo y hereje. Poco después, Enrique VIII de Inglaterra, no reconoce la autoridad del Papa de Roma y, por el Acta de Supremacía Real, funda la iglesia anglicana que unifica en la persona del rey o reina la autoridad suprema celestial y terrenal. La unidad cultural de la Europa católica se va a desgajar en dos grandes bloques: los católicos que aceptan la autoridad del Papa y los protestantes que la rechazan. Esta división se traducirá en una división de los Estados alineados con una u otra religión, factor que se va superponer, incluso a fundir, a las larvadas guerras comerciales por las nuevas rutas marítimas.

En la primera parte de este trabajo, al hablar de las trasformaciones en Barcelona introducíamos el concepto de "destrucción creadora" que planteaba el proceso, continuo y continuado, del hacer ciudad. ¿Cómo algunas personas pudieron realizar las operaciones que llevaron a la construcción de las Vilas Novas? De un modo u otro (comercio, saqueo, explotación agraria...) estas personas consiguieron acumular un capital dinerario suficiente (o pidieron préstamos a los incipientes bancos) para poderlas realizar aunque fuera en el modo de enfiteusis. Una tendencia habitual del capital, es buscar refugio y seguridad invirtiendo en bienes raíces. Cuando esta inversión se realiza en áreas construidas, se inicia un proceso de destrucción construcción, que, en el plano cultural y como señalaba Vasari, supone la erradicación de unas determinadas formas y su substitución por otras. En este sentido, una revolución en las relaciones temporales y espaciales a menudo implica, no solo la destrucción de formas de vida y prácticas sociales construidas alrededor de sistemas tempo-espaciales precedentes, sino la "destrucción creativa" de una amplia gama de activos físicos incrustados en el paisaje (Harvey 1996: 241).

5 "El estilo gótico fue creado por Suger, abad de St. Denis, consejero de dos reyes de Francia, el Renacimiento por los mercaderes de Florencia, banqueros de los reyes de Europa" (Pevsner 1945: 218) 


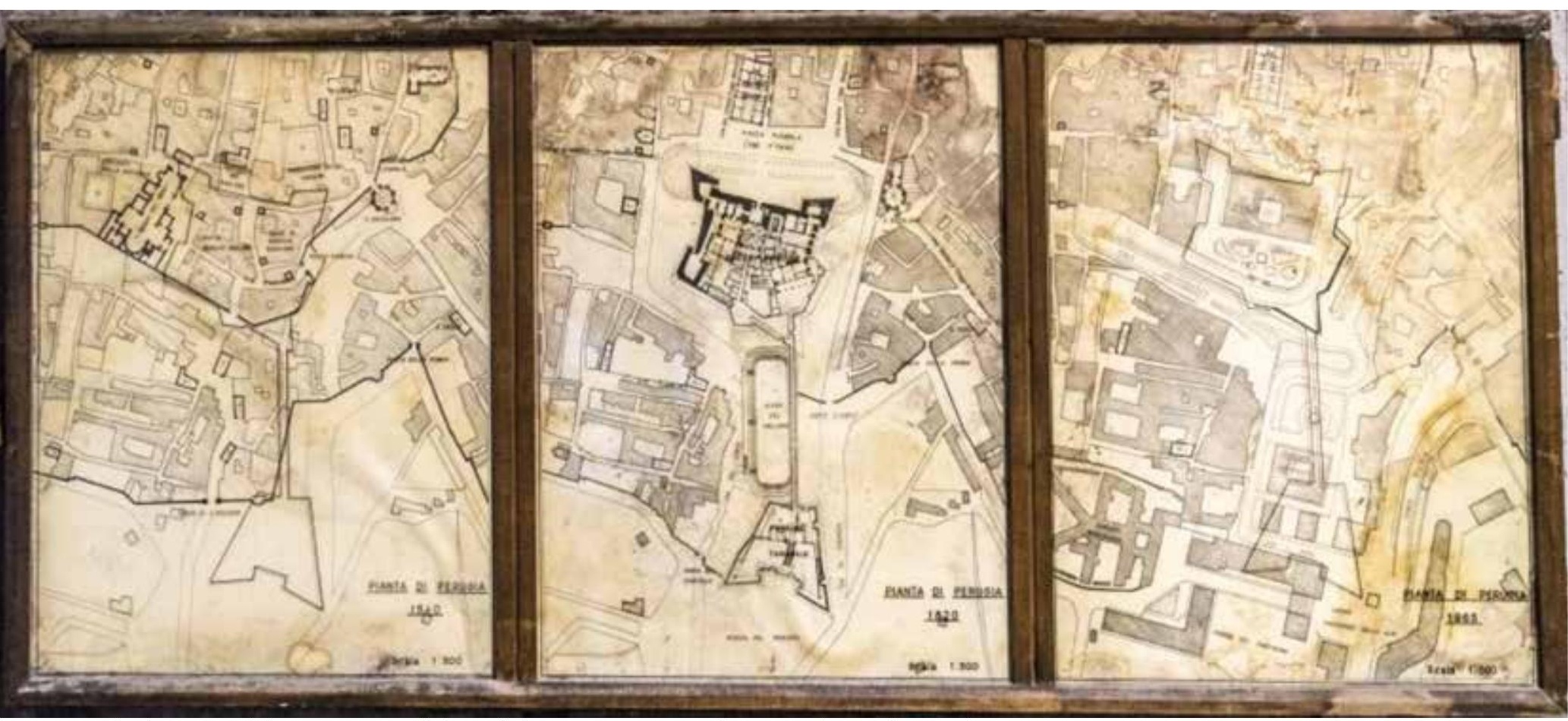

Panel informativo del Ayuntamiento de la ciudad en que se aprecia el proceso de transformación

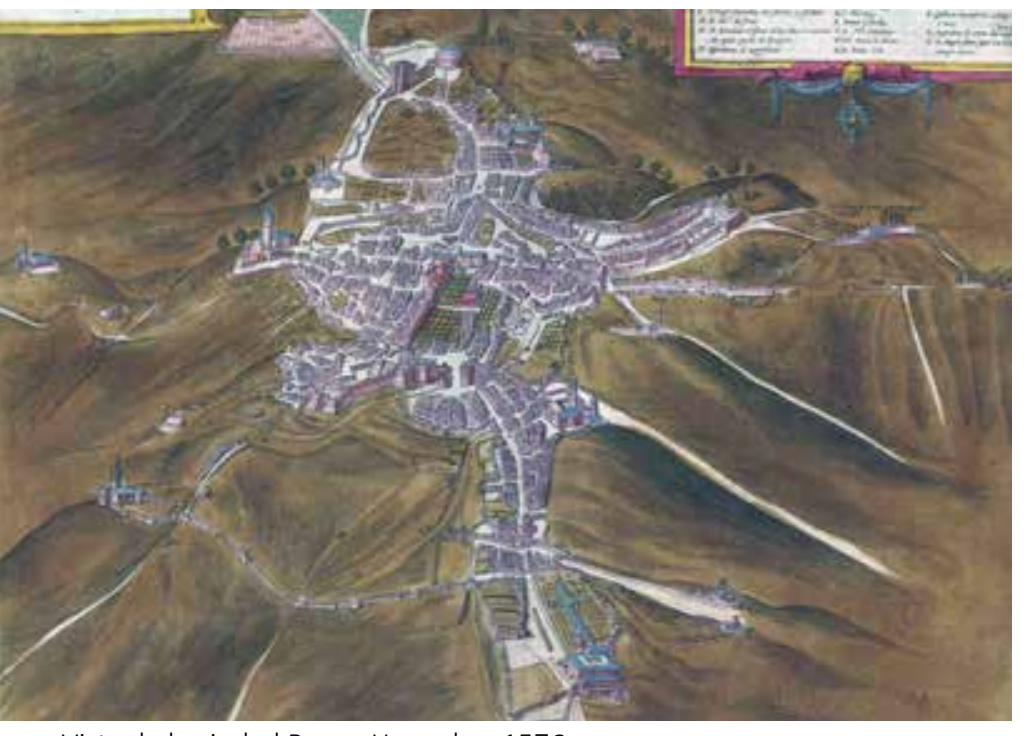

Vista de la ciudad Braun-Hogenber 1576

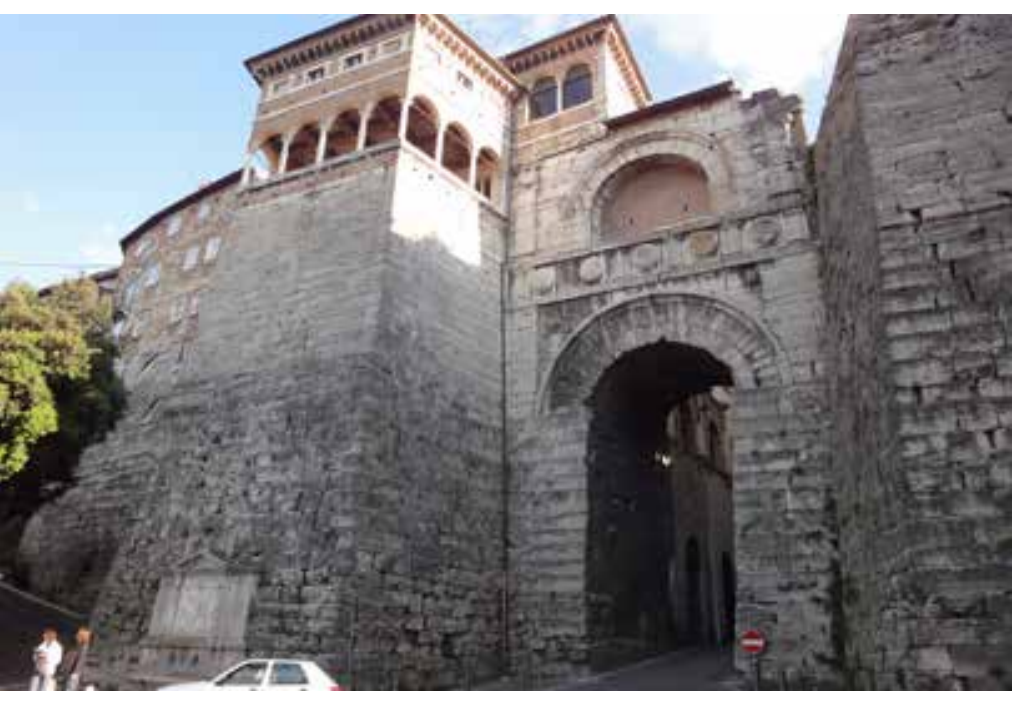

Restos de la muralla etrusca

\section{Perugia}

Situada en la región de Umbría, es una ciudad de fundación etrusca. Entre los siglos XIII y $\mathrm{XIV}$, tiene un gran desarrollo urbanístico: se construyen varias obras, entre ellas la Fontana Maggiore (1275-77), proyectada por Nicolo y Giovanni Pisano con la colaboración de Fray Bevignate da Cingoli para la parte arquitectónica y de Boninsegna Veneziano para la parte hidráulica. La fuente estaba alimentada por las aguas del acueducto provenientes del Monte Pacciano (125476). Es un período de gobierno ejercido por los Priores, elegidos entre los miembros de las 'artes' y con sede en el Palazzo dei Priori construido a lo largo de los siglos XIII-XV y con distintas actuaciones.

En 1308 ya tiene Universidad y en 1319, Perugia eligió San Ludovico di Tolosa como "Abogado de la ciudad y del Palazzo dei Priori". En el siglo XIV Perugia ya está en una fase de declive, especialmente a partir de la epidemia de peste negra de 1348. A inicios del siglo XV la ciudad pasa a manos del Ducado de Milán, del Pontífice y hasta del rey de Nápoles. Una revuelta popular entrega el poder de la ciudad al condottiero Braccio da Montone hasta que la familiar Baglioni consigue el control político de la ciudad.

En 1540 la ciudad pierde su autonomía, pasa a depender del Pontificado, cuando el papa Pablo III decidió construir una gran fortalezapalacio, con proyecto de Antonio da Sangallo 
el joven y para ello fueron demolidas veintiséis torres, once iglesias, dos monasterios, parte de la antigua muralla etrusca y unas trescientas casas. La Fortaleza Paolina fue construida entre 1540 y 1543.

La razón por la que el Papa decidió construirla no fue la clásica de proteger la ciudad de las incursiones externas, sino la demostración de la fuerza y el poder de un Papa que quería imponerse a los señores, en este caso a los Baglioni. Tras la demolición, en el siglo XIX, del vasto complejo del siglo XVI, solo restan los subterráneos actuales.

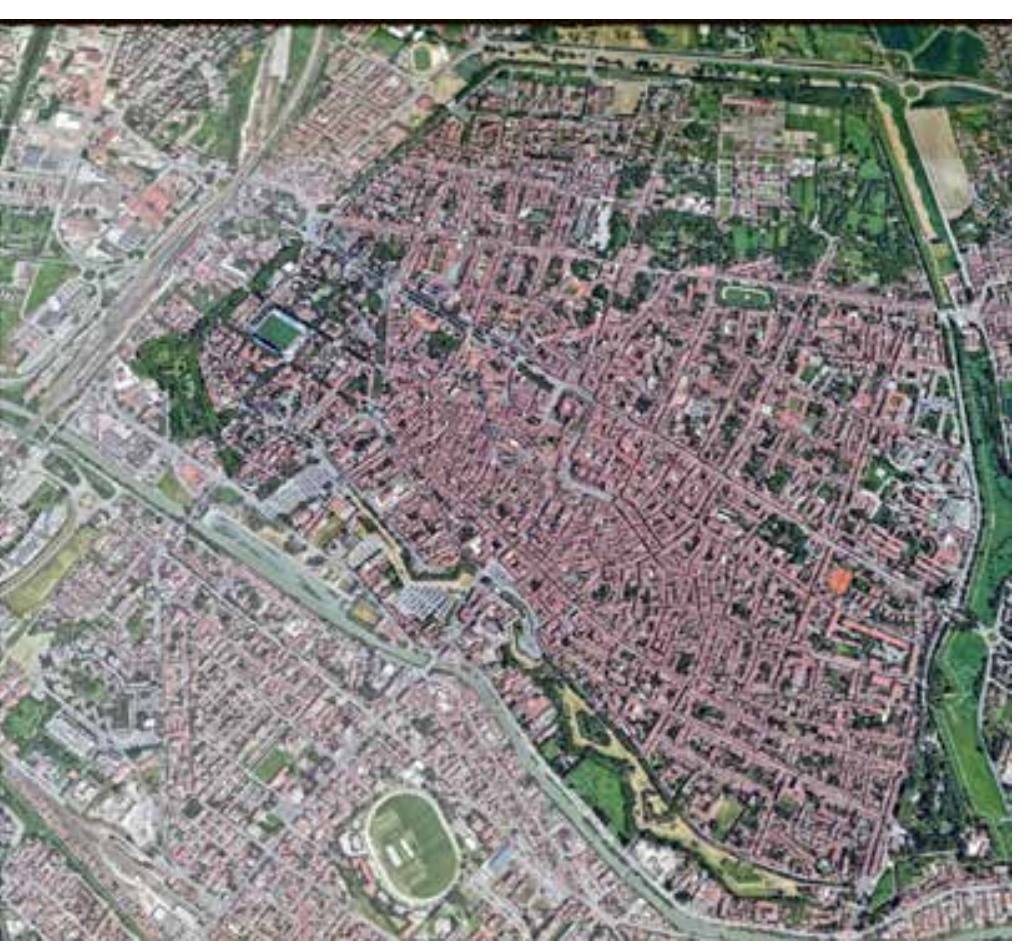

Vista actual de Ferrara (C) Google Earth

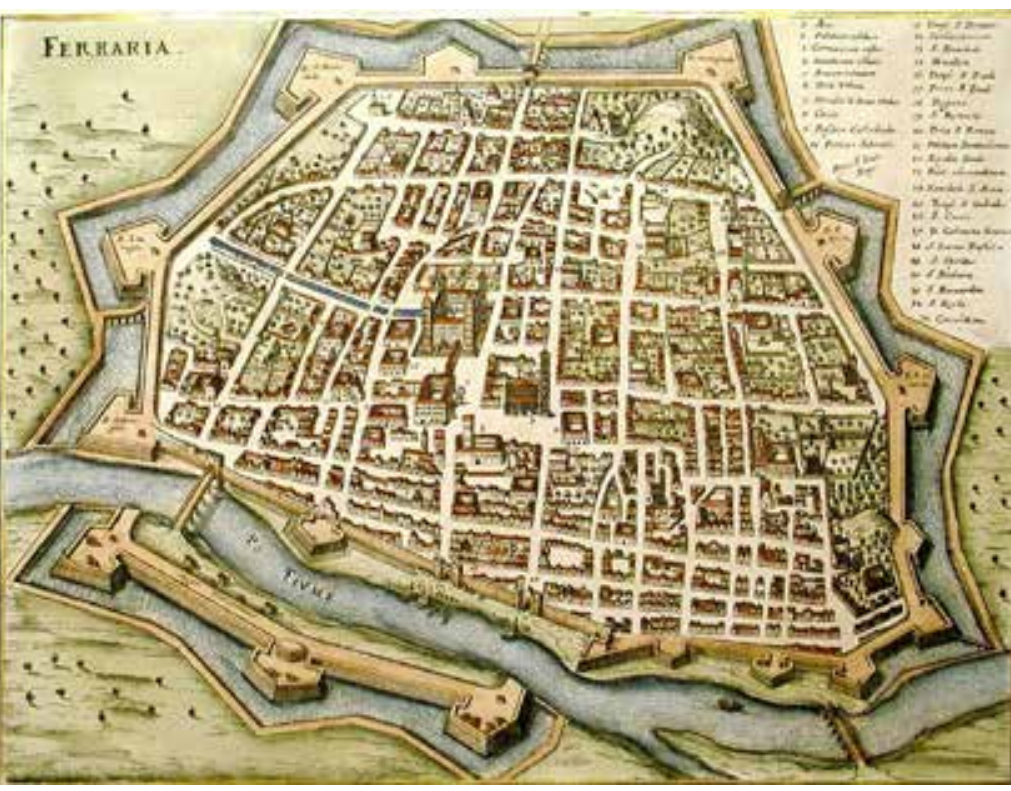

Braun- Hogenberg 1527
Ferrara

A finales del siglo XV Ferrara inicia un proceso de renovación interna y de ensanche (addizione) de la ciudad. La 'Addizione Erculea' consiste en tres 'addizioni' progresivas con el objetivo de reconfigurar la ciudad y mejorar su sistema defensivo. La primera fue realizada por Nicolo II y diseñada por Bartolino de Novara. Consistió en una expansión de la ciudad sin incorporar nuevos 'burgos', pero cerrando un gran espacio abierto (Pratum Bestiarum) urbanizado con nuevos edificios y vías rectas cuyo eje vial principal era la Strada di San Francesco.

El marqués Borso d’Este realizó la segunda, interviniendo el camino del río Po al sur de la ciudad, enterrándolo parcialmente, siguiendo el camino de Ficarolo. Se trazó la llamada Strada della Ghiara, que se convirtió en la columna vertebral de la nueva ampliación mientras se unían una serie de calles menores perpendiculares a la principal con el antiguo tejido urbano.

La addizione Erculea propiamente dicha, fue realizada por la voluntad del duque Ercole I d'Este entre 1492 y 1510 y fue proyectada por Baggio Rossetti. Las obras de ampliación se iniciaron en 1492 con el trazado del nuevo tramo de las murallas y, poco después, se empezó a cavar un largo foso de más de 30 metros de ancho. Rossetti pensó en dos calles principales, perpendiculares entre sí. La Via dei Prioni - orientada como decumanusllamada así porque estaba pavimentada con grandes piedras, los "priones", conectaba la Porta di San Giovanni al este con la de San Benedetto al oeste. A un lado de esta calle, en una posición descentralizada, Rossetti creó una plaza arbolada como lugar de reunión social y mercado, la Piazza Nova. El eje que cruzaba la Via dei Prioni, -posicionado como un cardo- era la Via degli Angeli. Esta calle fue pavimentada y plantada con álamos. 

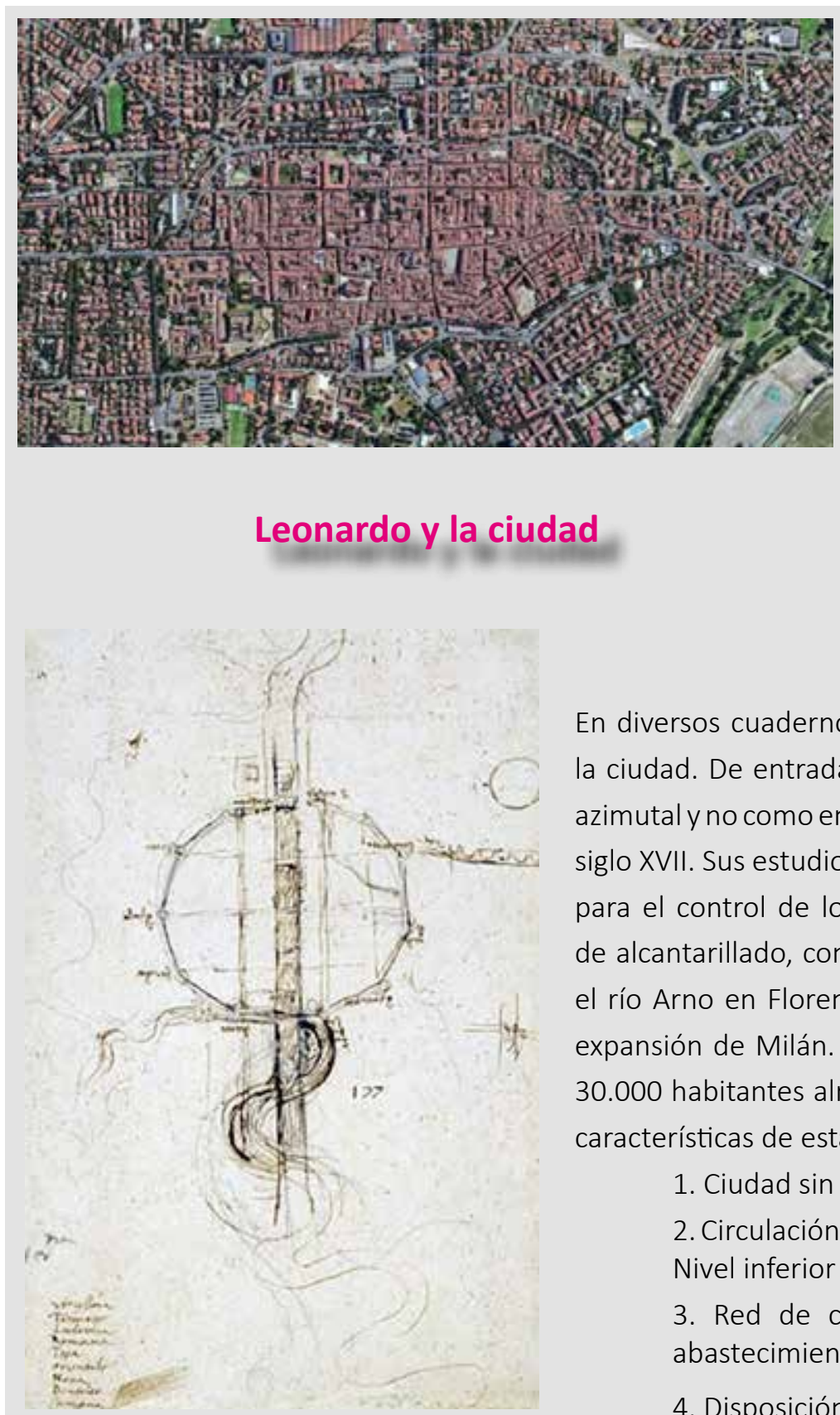

Leonardo. Propuesta de Plan para la Ciudad de Florencia. (c) Códice Windsor, lámina 12681. Fuente: Biblioteca Ambrosiana de Vinci.
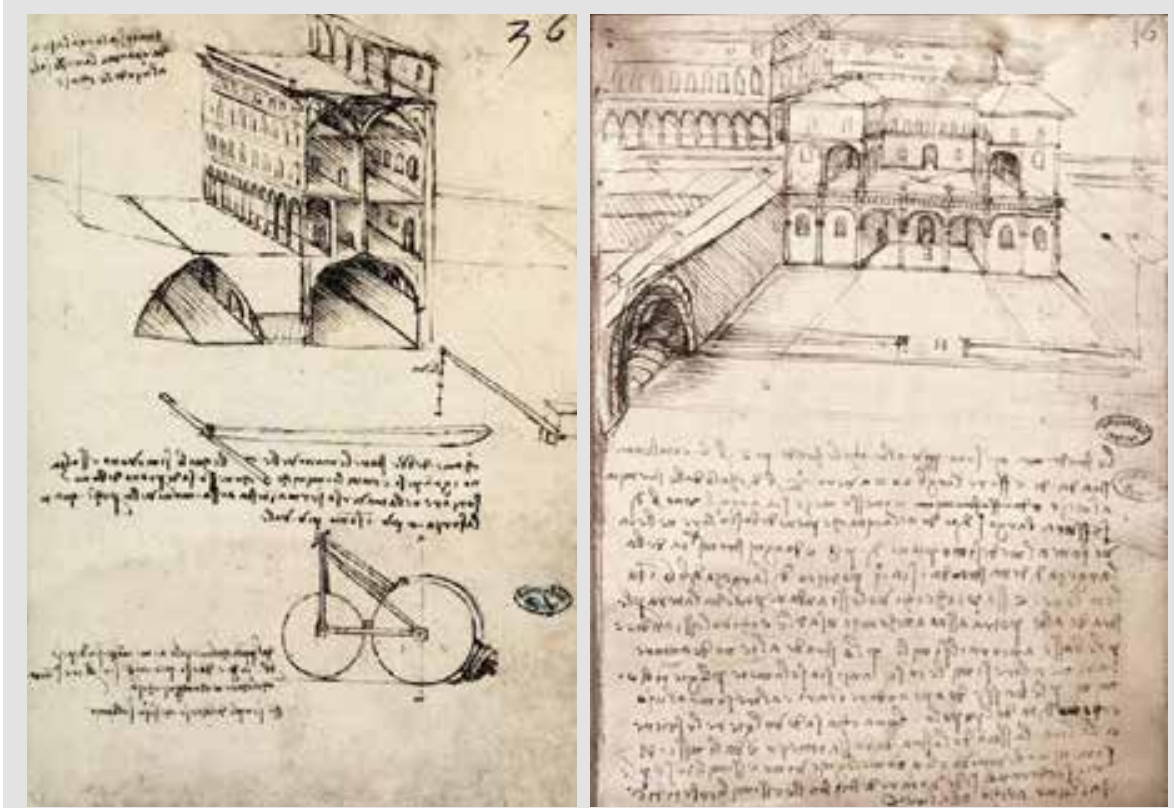

En diversos cuadernos de trabajo de Leonardo, aparecen algunas ideas acerca de la ciudad. De entrada Leonardo trabaja las plantas de la ciudades desde una vista azimutal y no como en las "vedutte" adelantándose algún tiempo a los cartógrafos del siglo XVII. Sus estudios sobre mecánica e hidráulica introducen esquemas racionales para el control de los cursos de agua, pero también para el trazado de sistemas de alcantarillado, como sucede con el esquema propuesto para desviar y canalizar el río Arno en Florencia. Finalmente, Leonardo tiene una idea innovadora para la expansión de Milán. Propone crear una serie de ciudades de nueva planta y para 30.000 habitantes alrededor de Milán. Como señala Hidalgo (2014), las principales características de estas ciudades son

\section{Ciudad sin amurallar.}

2. Circulación a distinto nivel: Nivel superior abierto para tránsito de personas. Nivel inferior cerrado y para el tránsito de carros y mercancías.

3. Red de canales que permiten mejoras en el saneamiento y en el abastecimientode la ciudad.

4. Disposición de grandes espacios libres y abiertos

Leonardo.

1487-1489. Ideas para posible ciudades periféricas de Milan (C) Códice B Biblioteca Ambrosiana de Vinci Fol. $16 r, 36 r, 47 r$
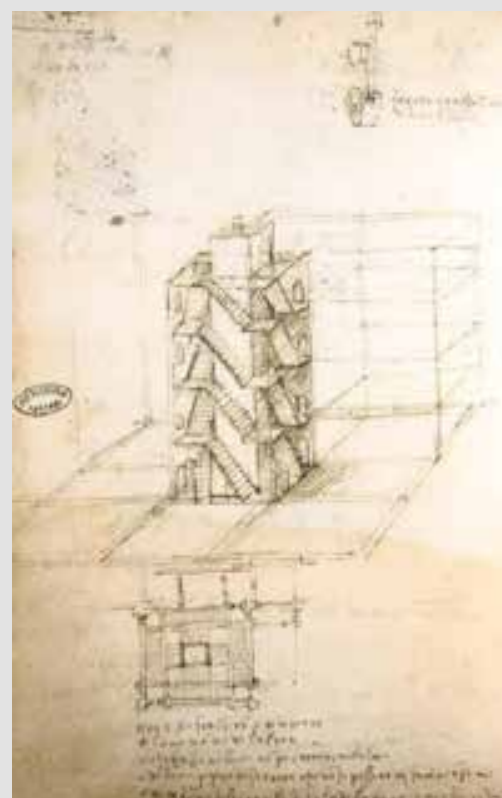


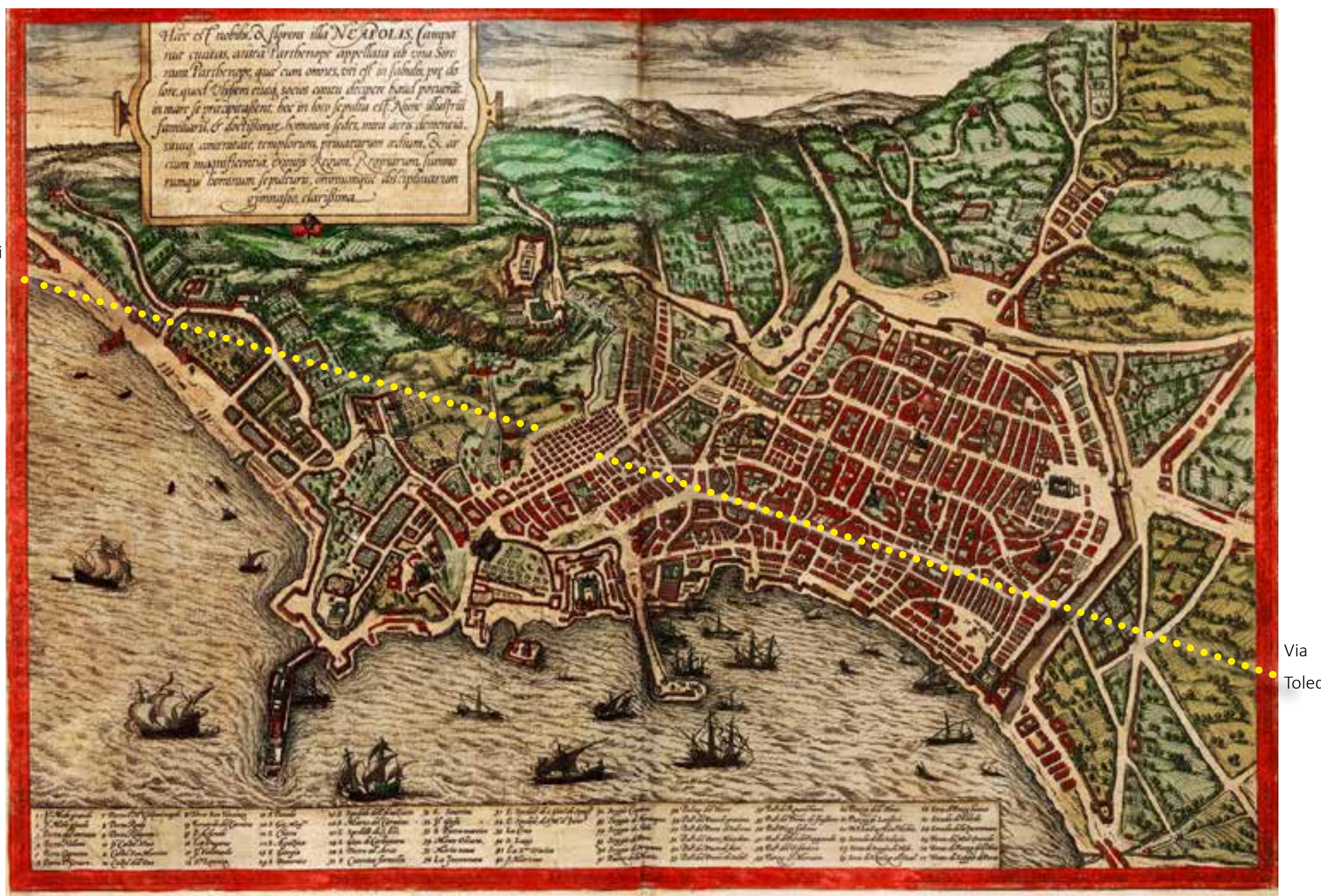

Braun- Hogenberg (s.XVI)

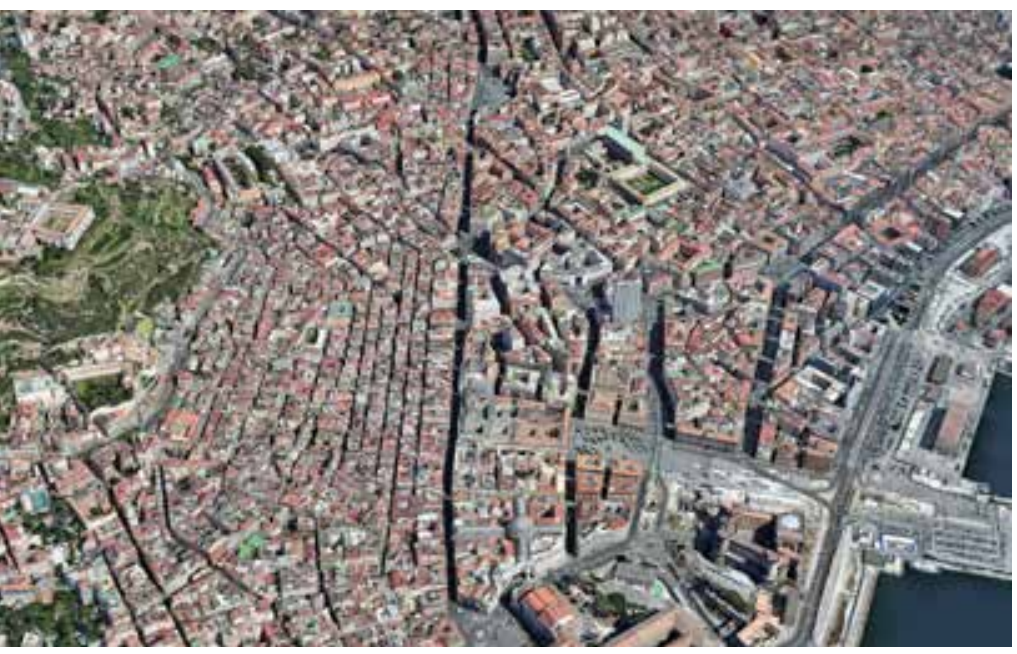

Vista del corte de la vía Toledo (derecha) y trama regular del Quartieri Spagnolli (izda) (c) Google Earth.
Nápoles

En la primera parte de este trabajo, vimos como Nápoles, podía considerarse un ejemplo de claro de policentralidad (Remesar 2021). Bajo dominio de la corona Habsburgo, Nápoles se convirtió en una de las bases de la ruta de Flandes, lo que le aportaría mayor riqueza y prosperidad, al mismo tiempo que un aumento constante de población. Nápoles pasara de 220.000 habitantes a mediados del siglo XVI a unos 450.000 habitantes a comienzos del siglo XVII. Poco a poco la ciudad crece hacia las colinas y, saltando la muralla, hacia la zona de costa. La vivienda precaria se convierte en parte del paisaje urbano. Los puestos y mostradores de las tiendas sirven muchas veces de alojamiento durante la noche. Al final del s XVII se pueden identificar en la plaza del Mercado 151 barracas.

En el siglo XVI podemos señalar dos grandes operaciones urbanas: el trazado de la vía Toledo y la creación del 'quatieri spagnoli'. Desde el siglo XVI, el centro administrativo y 


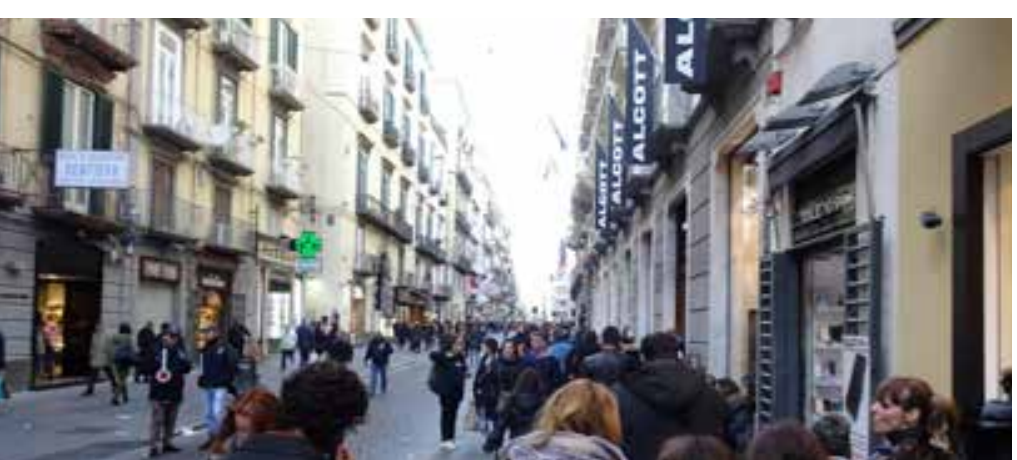

Trazado rectilíneo de la Vía Toledo hoy convertida en una arteria comercial
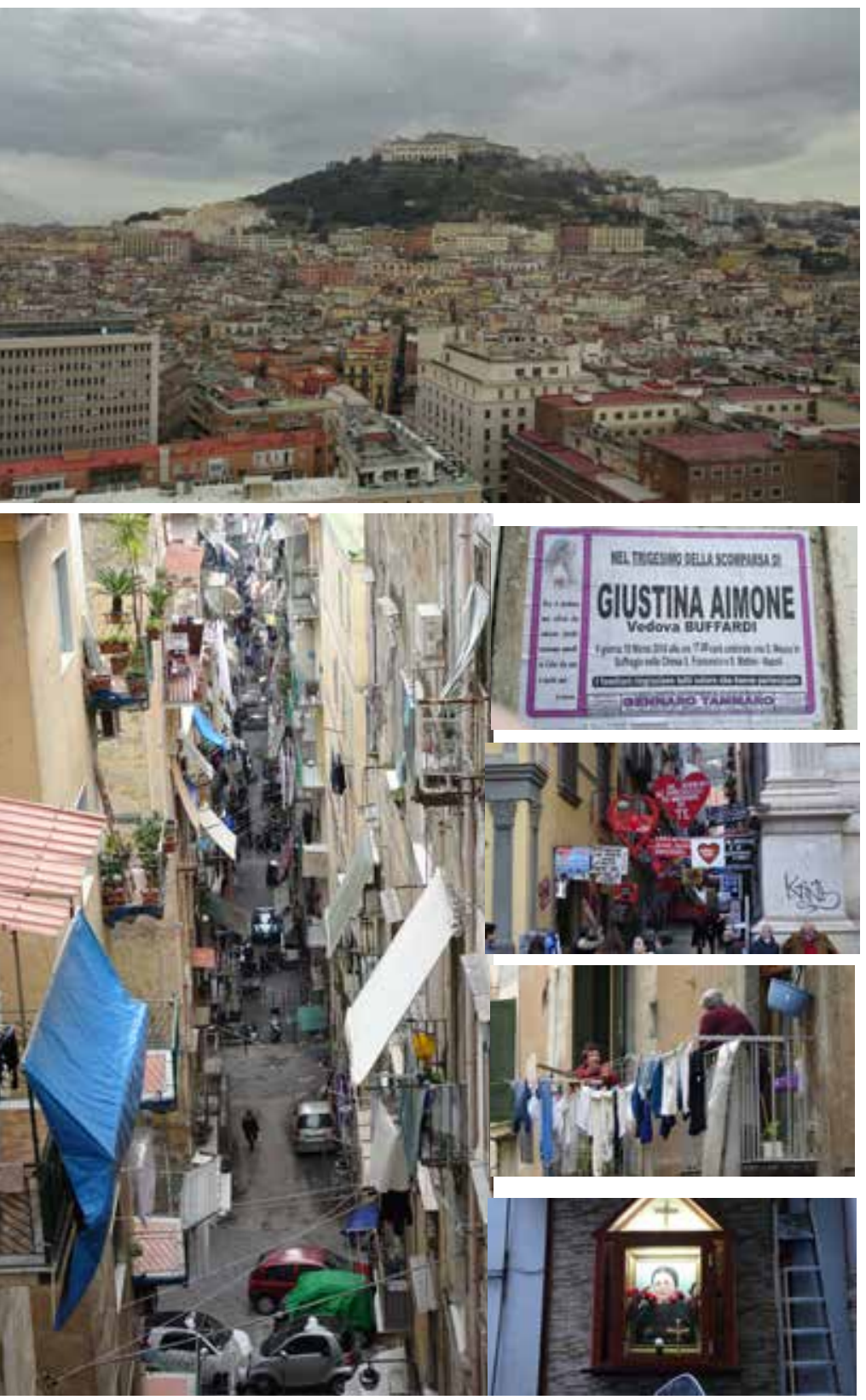

Diversas vistas del Quartieri Spagnolli. Un barrio intrincado, repleto de altares cuyas velas, hasta hace pocas décadas, eran la única iluminación de las calles.

Un barrio populoso y popular en el que Maradona es el Rey puesto que desde 2021 se han retirado los altares dedicados a la memoria de miembros de la Camorra. comercial de Nápoles fue creciendo en torno a Toledo y Castel Nuovo.

Via Toledo. Fue construida por el virrey Pedro Álvarez de Toledo- de donde viene el nombreen 1536 según el proyecto de los arquitectos reales Ferdinando Manlio y Giovanni Benincasa. La calle discurre a lo largo de la antigua muralla occidental de época Catalanoaragonesa que quedó obsoleta por diversas ampliaciones defensivas y por ello se derribó. Es una calle ancha, rectilínea de unos $15 \mathrm{~m}$ de anchura, que se ha convertido en uno de los lugares más emblemáticos de la ciudad, por lo que el nombre de «Vía Roma», con el que fue rebautizada oficialmente en 1870 , no consiguió destronar su vieja denominación 'toledana' en el identitario napolitano.

'Quartieri Spagnoli'. El conjunto urbano conocido como 'Quartieri Spagnoli'- barrio español o de cuarteles de los españoles- surgió en la primera mitad del siglo XVI, en paralelo a la vía Toledo. Es obra del arquitecto sienés Giovanni Benincasa y del napolitano Ferdinando Manlio. Fue mandado edificar por el virrey Toledo con un trazado ortogonal, con manzanas cuadradas (aprox. $21 \times 23 \mathrm{~m}$ ) y rectangulares (aprox de $26 \times 40 \mathrm{~m}$ ), de calles estrechas (aprox. $5 \mathrm{~m}$ ) y en pendiente.

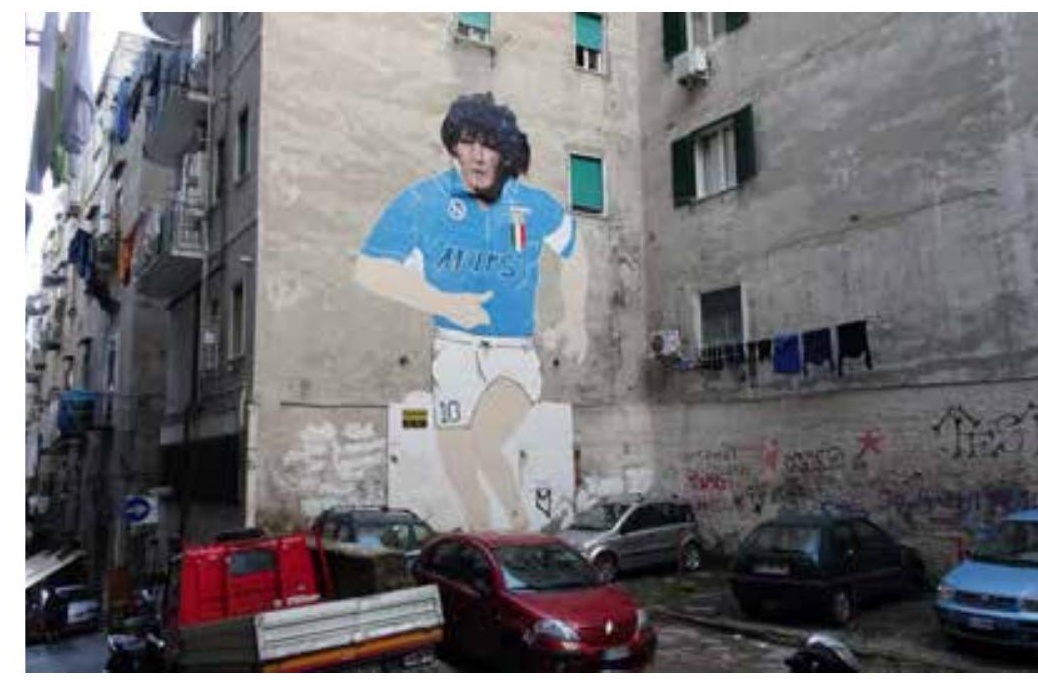




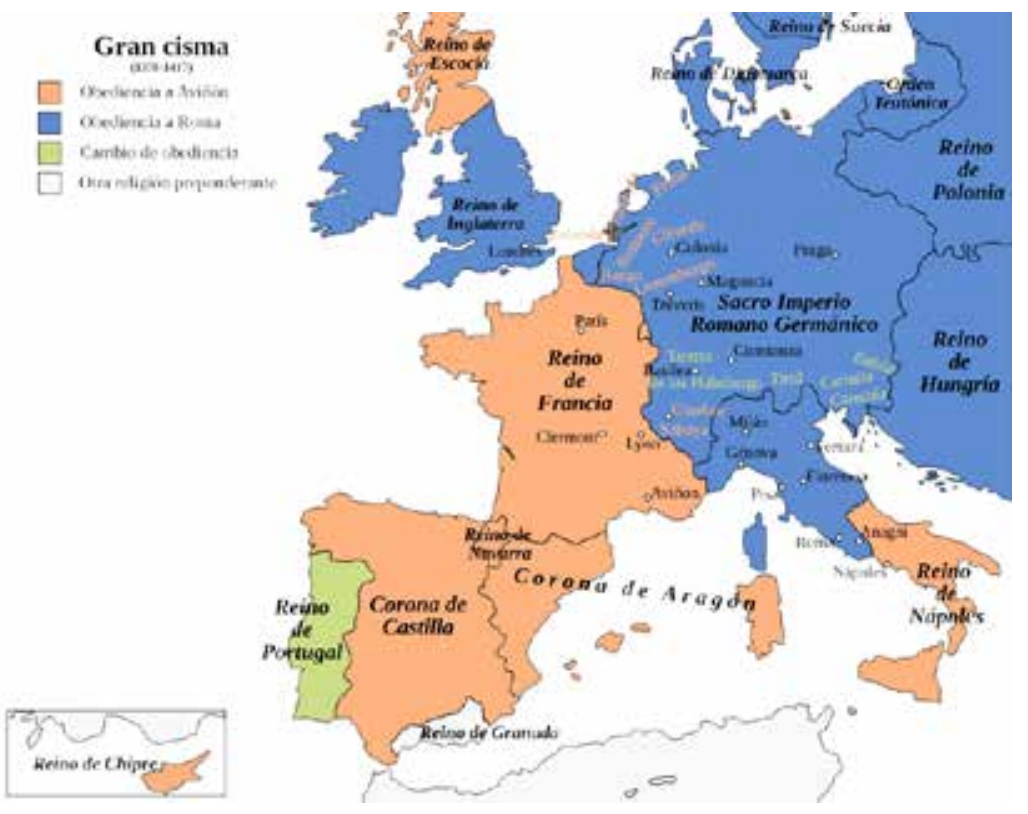

Europa durante el Cisma de Occidente (C) Creative Commons

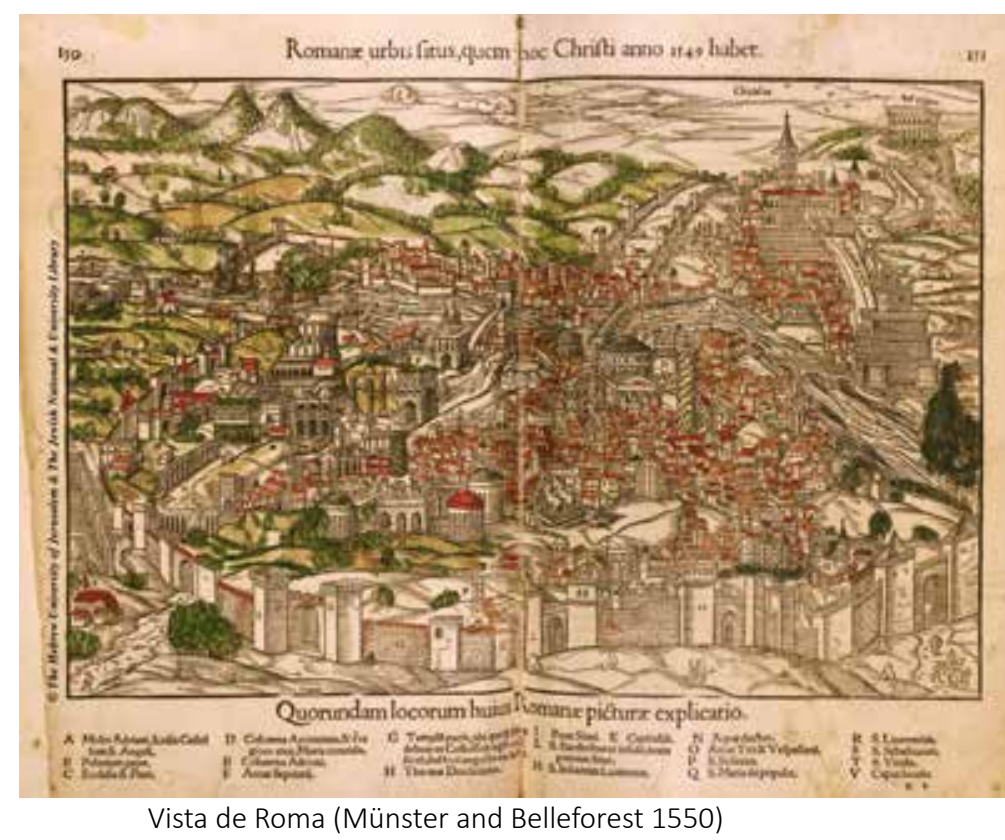

toda la Europa cristiana estuvo excomulgada en el marco del llamado Cisma de Occidente por el que existieron al unísono dos Papas, uno con sede en Roma, el otro con sede en Aviñón. Hecho que afectaría a las peregrinaciones.

Restaurada la sede papal en Roma desde mitad del siglo XV distintos papas enfrentan una renovación de la ciudad de Roma. Esta renovación tenía como objetivo central constituir un nuevo centro en el entorno de la basílica de San Pedro. Complementariamente, pretendía facilitar las conexiones entre las distintas zonas de la ciudad para facilitar el acceso de los peregrinos a la basílica de San Pedro, lo que suponía plantearse qué papel debía tener la preservación e integración de los restos arqueológicos y edificados de la época del Imperio Romano en la configuración de la ciudad que, además, desde la caída de Constantinopla (1453) en manos de los turcos, volvía a ser el gran referente simbólico y espiritual de la Cristiandad.

Nicolás V trasladará la residencia papal al Castelo de Sant'Angelo que requerirá la construcción de un nuevo puente sobre el Tiber. Asesorado por Alberti actuará en la mejora de las infraestructuras hidráulicas de la ciudad, abrirá nuevas calles orientadas a conseguir la centralidad del Vaticano, creará nuevas plazas. Después, Sixto $\vee$ ampliará el trazado de nuevas calles, construirá nuevos puentes y reforzará la estructura portuaria de Roma.

Como parte de una estrategia defensiva para reforzar el castillo de Sant'Angelo, el español Alejandro VI Borgia (1492-1503) generó una nueva calle, Via Alessandrina (ahora Via Borgo Nuovo), a través del Borgo para conseguir un enlace directo entre su puerta de entrada y el Vaticano. Si bien su inauguración coincidió con el Jubileo de 1500 , no estaba pensada como una calle de peregrinaje a San Pedro, sino como 


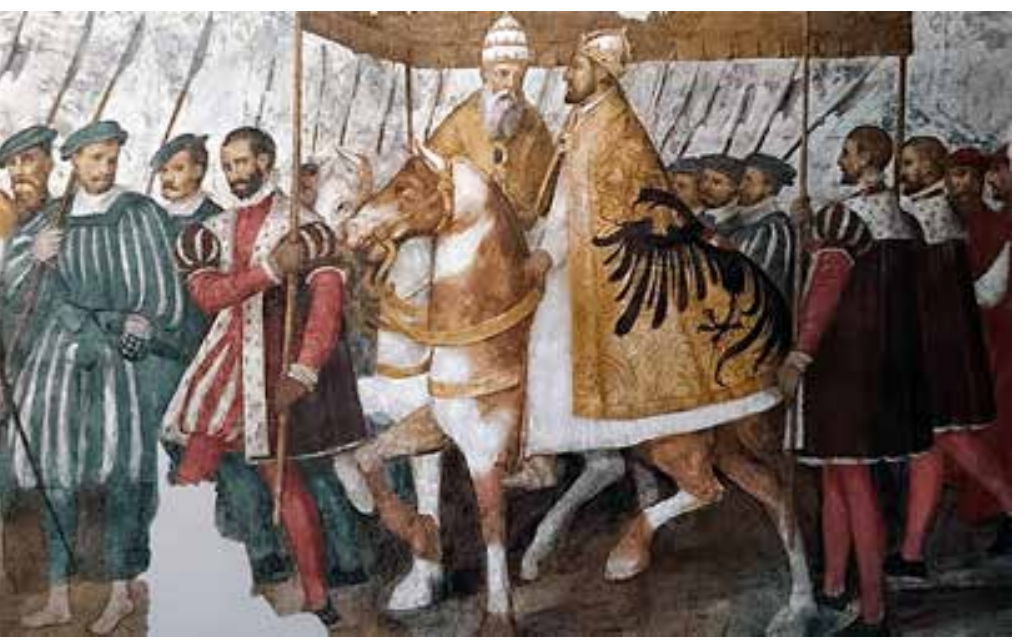

Ermano y Jacopo Ligozzi 'Cavalcata di carlo V e clemente VII a Bologna', (1570-80) com motivo de la segunda coronación del emperador [Fragmento] (C) Museo degli affreschi Giovanni Battista Cavalcaselle

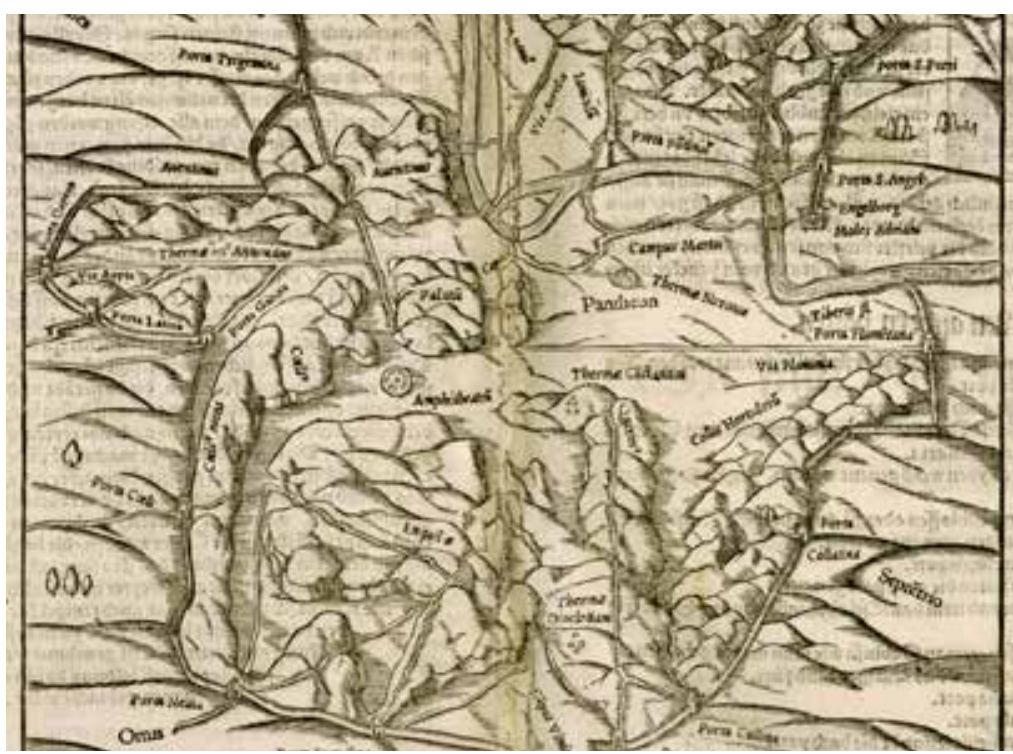

Grabado de 'Cosmografía' (Münster and Belleforest 1550)

una ruta procesional para los dignatarios que llegaban al Vaticano. Para atraer nuevos desarrollos acordes a la aristocracia de la Iglesia, Alejandro ordenó a varios propietarios que construyeran imponentes palacios donde su calle confluía con la Piazza Scossacavalli.

En 1503 Julio II inicia las obras de la nueva basílica de San Pedro, con sucesivos proyectos de Bramante, Rafael y Miguel Ángel. Julio II Della Rovere implementó su plan para conectar Borgo y Rione, con un puente sobre el río Tíber. Comenzó ensanchando la 'Via de Banchi' en la Piazza Ponte e instalando la casa de la moneda papal en su cabecera para encarar el Castel Sant'Angelo. Su plan incluía reconstruir el Pons Neronianus, abandonado durante mucho tiempo, y vincularlo a una nueva calle, Via Giulia. Una de las calles importantes de la época es la 'via Corso' de unos $15 \mathrm{~m}$ de anchura? .

León $X$ reactivará la construcción de San Pedro y para ello iniciará una venta masiva de indulgencias (ver nota 6 ), abriendo, de este modo, la vía para la Reforma protestante. Además, continuó, en la línea de Julio II, trazando la Via Leonina para conectar la Piazza del Popolo directamente con el puerto de Ripetta; desde allí continuó con la Via Sixtina, hacia la iglesia de S. Luigi dei Francesi, y su propio palacio.

En 1527 las tropas, alemanas, italianas y españolas, de Carlos V saquean Roma en el conocido Sacco di Roma ${ }^{8}$, detienen al papa Clemente VII que debe pagar una gran 7 El nombre 'Corso' dará lugar a una estructura viaria que se desarrollará en el siglo XVII, consistente en una ancha via, generalmente con plantaciones de árboles y que con posterioridad pasará a llamarse avenida o bulevard

8 El papa Clemente VII dio su apoyo a Francia en un intento por alterar el equilibrio de fuerzas en la región, y liberar al Papado de lo que se percibía como la «dominación imperial» del Sacro Imperio Romano Germánico sobre la autoridad papal. Tras derrotar al ejército francés en Italia, Carlos V no disponía de fondos para pagar a los soldados que se amotinaron e iniciaron una marcha sobre Roma. Más de 30.000 soldados entraron al asalto en la ciudad y la saquearon durante tres días; hubo más de seis mil muertos, toda la ciudad fue saqueada y una gran parte incendiada. 
suma para su liberación, mientras que las tropas ocupantes se instalan en la ciudad durante nueve meses. Clemente VII coronará a Carlos V como emperador del Sacro Imperio en 1530 en Bolonia. Sin embargo, el emperador no visitará Roma hasta 1538.

Con motivo de esta visita, Paulo III encarga a Miguel Ángel la fijación definitiva de la forma de la ciudad. El artista coordina la mejora de las puertas de la ciudad, simplifica el proyecto de la basílica de San Pedro y realiza un proyecto para la reordenación del Campidoglio. Un proyecto que será completado casi 400 años después con la ejecución del pavimento por mandato de Mussolini.

"Su visita impulsó a Pablo III a reorganizar la abarrotada Colina Capitolina en 1538 según el brillante diseño de Miguel Ángel. Esto recalibró el orden urbano de Roma invirtiendo la orientación de la plaza. La plaza de la cima de la colina, que antes se abría hacia el sur hacia el Foro, ahora miraba hacia el Campo Marzo y el Vaticano hacia el noroeste. Una rampa triunfal Ilamada 'Cordonata', apta para caballos y carruajes, proporcionó un gran ascenso axial. Las fachadas renacentistas enmascararon los edificios existentes frente a la plaza y se agregó un nuevo palacio en un lado para equilibrar la composición. En el centro de la plaza trapezoidal se encontraba el punto focal de todo el conjunto, una antigua estatua ecuestre de Marco Aurelio extraída de Letrán. El plan también conectaba el Capitolio con la iglesia del 'Gesù' con una nueva calle recta, Via Capitolina (ahora Via d'Aracoeli), creando un desvío a lo largo de Via Papale que permitía a los peregrinos ascender por la Cordonata y descender al Foro". (Taylor et al 2016)

Como señala Giedion, Pablo III introduce un artefacto urbano, utilizado tímidamente en la Edad Media, que será ampliamente utilizado en el diseño urbano posterior especialmente en el barroco: el trivium ${ }^{9}$. El 'trivium' consiste en el trazado de tres calles rectilíneas que parten de un punto (en su caso la plaza del Popolo) irrumpiendo y 'sventrando' la ciudad construida.

"Este 'trivium' proporcionó un marco para el futuro desarrollo de su plaza y para las calles rectas y bloques regulares que caracterizan el norte de Campo Marzio. Paulo completó un segundo 'trivium' ampliando la Via Papale al entrar en Piazza di Ponte con dos nuevas calles que atraviesan un barrio denso". (Giedion 1941)

Es en este sentido que Tafuri vincula las actuaciones de Paulo III con las realizadas por su antecesor Julio II

"El pontificado de Alessandro Farnese [Paulo III], sin embargo, es más directamente comparable al de Julio II que al de Clemente VII. El triunfalismo retórico del sistema urbano asociado al Palazzo Farnese se confirma por la transformación en tridentes tanto del gran 'bivium' leonino como del más 9 "Pablo III Farnesio (1534-1549), el primer papa romano en casi 90 años, claramente se había contagiado del virus de la racionalización y lo había desplegado por toda la ciudad. Primero, construyó Via Paolina (ahora Babuino) al este de Via del Corso para equilibrar Via Leonina. Su conjunto de calles que irradian hacia el sur desde la Piazza del Popolo fue el primer 'trivium' formal, un tridente de calles diseñado para facilitar el movimiento. Esta nueva estrategia urbana, inventada en Roma, se abrió camino en los planos de villas y ciudades desde Versalles hasta Washington, D.C". (Giedion 1941) 
pequeño diseñado por Antonio el Joven en la época clementina (canal de Ponte - vía Paola). Los signos perentorios y teatrales quedan impresos por Pablo III en el cuerpo de la ciudad: la medida, la soltura, la variedad del arte urbano de la época de los Medici, dan paso a un culto a la regularidad y la axialidad, que enfatiza todo lo proyectado en las intervenciones del Papa Della Rovere [Julio II] " (Tafuri 1992)

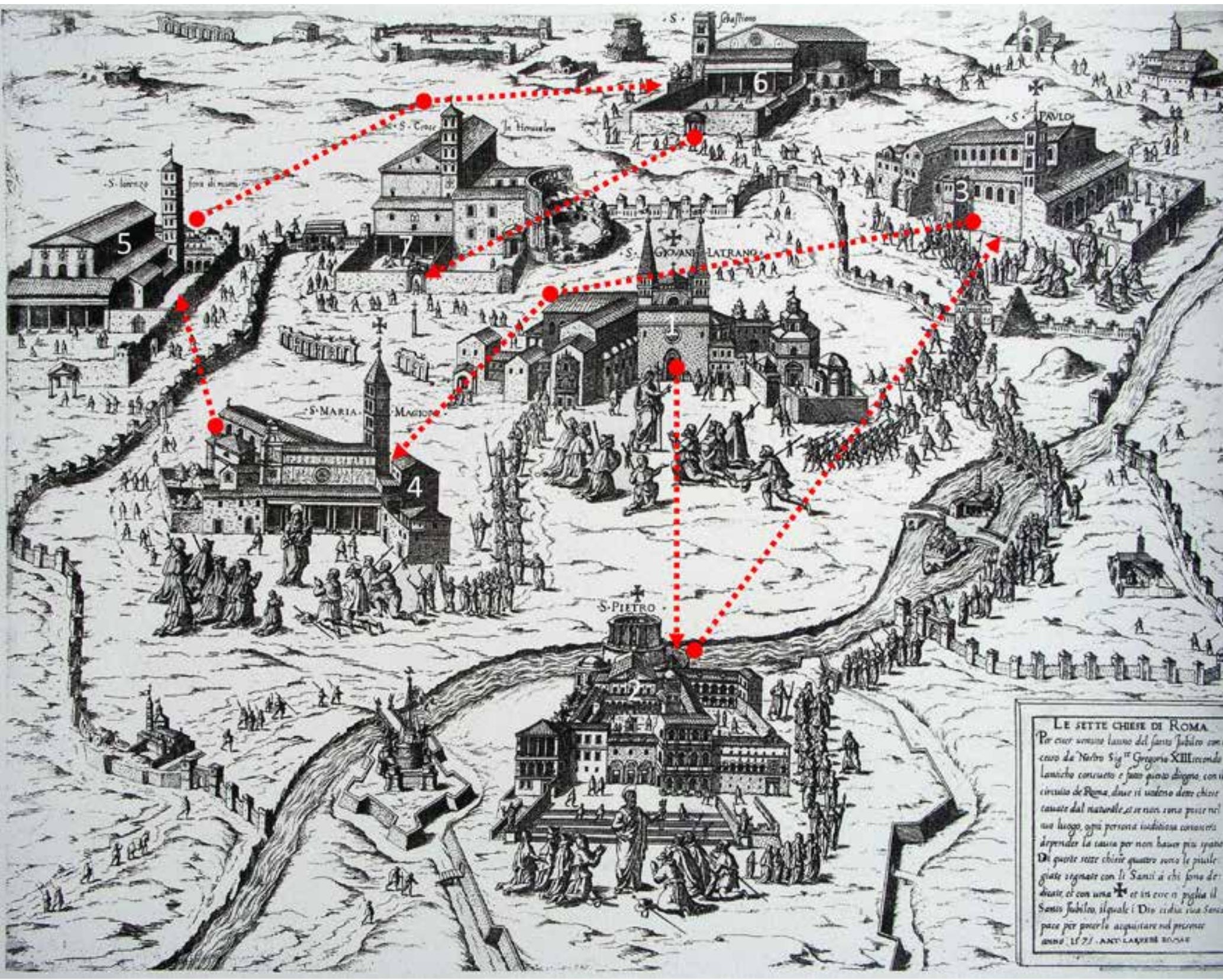

La ruta de las siete iglesias. Infografía a partir de la ruta de Francini (1595) sobre un grabado atribuido a Giovanni Ambrogio Branbilia y realizado por Antoine Lafréry,1575 @ Speculum Romanae Magnificentiae: The Seven Churches of Rome (Le Sette Chiese di Roma). METmuseum.org 
El grabado ${ }^{10}$ representa las siete basílicas intra y extramuros de la ciudad que debían visitar los peregrinos para conseguir la indulgencia plenaria una vez recorrido el largo camino entre su población de origen y Roma. La ruta adicional era de unos $25 \mathrm{Km}$. Aunque esta ruta ya se realizaba en la Edad Media, parece que San Felipe Neri y algunos de sus discípulos, la iniciaron de modo informal a principios de la década de 1540, al inicio de la Contrareforma. San Ignacio de Loyola, amigo de Felipe Neri, hizo la peregrinación de las siete iglesias el 22 de abril de 1541, con cinco compañeros cofundadores de la Compañía de Jesús. Ese día, los primeros seis jesuitas hicieron su profesión religiosa definitiva en la capilla del Santísimo Sacramento de la Basílica de San Pablo Extramuros.

La ruta cobró impulso durante el Año Jubilar de 1550 y se convirtió en una práctica estable y organizada desde 1559. Originalmente, la peregrinación duraba dos días (Miércoles y Jueves Santo), y fue concebida específicamente como una alternativa al carnaval profano. En 1575, la peregrinación a las siete iglesias se convirtió en requisito para obtener la indulgencia plenaria del Jubileo. Su recorrido se hará entonces durante todo el año y no sólo el Jueves Santo, como pre-Cuaresma. Las exigencias disminuyeron durante el post-jubileo en 1575.

Las siete iglesias ya aparecieron enumeradas en la guía de Girolamo Franzini (1595), en el siguiente orden: San Juan de Letrán, San Pedro, San Pablo Extramuros, Santa María la Mayor, San Lorenzo Extramuros, San Sebastián y Santa Cruz de Jerusalén.

\section{El plan de Sixto $V$}

La transformación urbana de Roma, en el auge de la Contrarreforma y del Manierismo, poco antes del llamado periodo Barroco, da un gran salto en el pontificado de Sixto V (1585-1590). A finales del siglo XVI Roma había duplicado su población pasando de unos 50.000 habitantes a mitad de siglo a los 100.000 que tendría al finalizar este siglo. Giovannoni $(1935 ; 1945)$ y Giedion $(1941)$ coinciden en atribuir al programa de Sixto $\checkmark$ el valor de Plan fundacional de ordenación de la ciudad-Giovannoni lo calificará de plan director, Giedion de Masterplan-y, por extensión, de la planificación global.

Doménico Fontana sería el arquitecto encargado de llevar a cabo las ideas del Papa.

10 El creciente número de peregrinos, pero también de visitantes y mandatarios internacionales, llevó a Antonio Salamanca y Antonio Lafréri, a imprimir diversas vistas de Roma. Los grabados registraban obras de arte, arquitectura y vistas de la ciudad relacionadas con la Roma antigua y moderna. Los peregrinos y coleccionistas podían comprar las impresiones individualmente, pero también se compraban en grupos más grandes que a menudo se unían en un álbum. En 1573, Lafréri encargó una portada para este propósito, que es donde aparece por primera vez el título "Speculum Romanae Magnificentiae". Cuando murió Lafreri, dos tercios de las planchas de cobre existentes restaron en posesión de la familia Duchetti (Claudio y Stefano), mientras que otro tercio se distribuyó entre varios editores. Los Duchetti parecen tener una producción estandarizada, ofreciendo una versión más o menos uniforme del Speculum a sus clientes. Sin embargo, la popularidad de las impresiones también inspiró a otros editores romanos a hacer copias y agregar nuevas impresiones al corpus. Se crearía una pujante industria de los 'recuerdos' que culminaría con el máximo exponente del trabajo de Piranesi (siglo XVIII) esta vez para proporcionar imágenes de recuerdo a los participantes en el Grand Tour. 


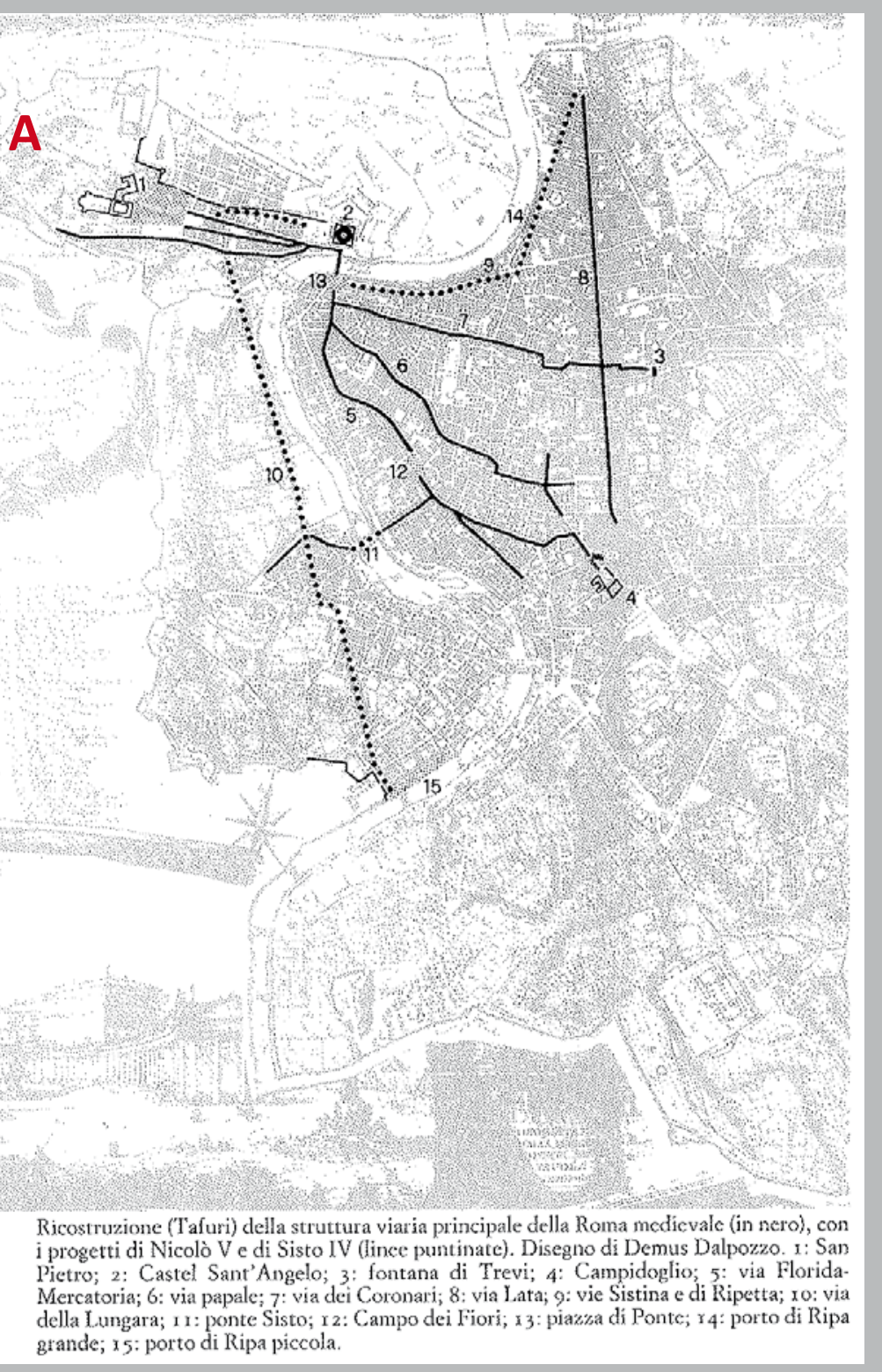

B

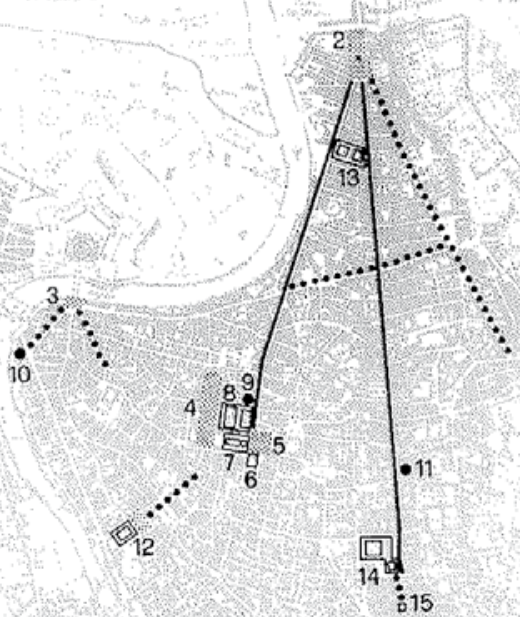

Ricostruzione (Tafuri) dei progetti a scala urbana di Leone $\mathrm{X}$ per Roma (1513-21); a puntini, gli interventi di Paolo III. Disegno di Demus Dalpozzo. x: San Pietro in Vaticano, se condo il primo progetto di Raffaello; 2: piazza del Popolo; 3 : via Paola e via di Panico convergenti su piazza di Ponte; 4: piazza Navona; 5: piazza della Dogana; 6: palazzo MediciLante: 7: Studio; 8: progetto sangallesco per un palazzo mediceo (cfr. la fig. 14); 9: area di

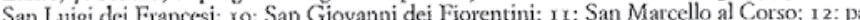
lazzo Farnese: 13: San Giacomo degli Spagnoli; r4: palazzo Venezia; 15: torre di Paolo III in Campidoglio.

'Sventramentos' de la Roma Medieval realizados por distintos planes papales. A-B Esquema realizado por Tafuri (1992) esquematizando las intervenciones de los papas Nicolas V, Sixto V, León X y Paulo III . C.- Superposición de las imágenes anteriores

\section{Los nuevos trazados para acceder al "centro" (Vaticano) agujerean y rompen la ciudad medieval}

\section{C}

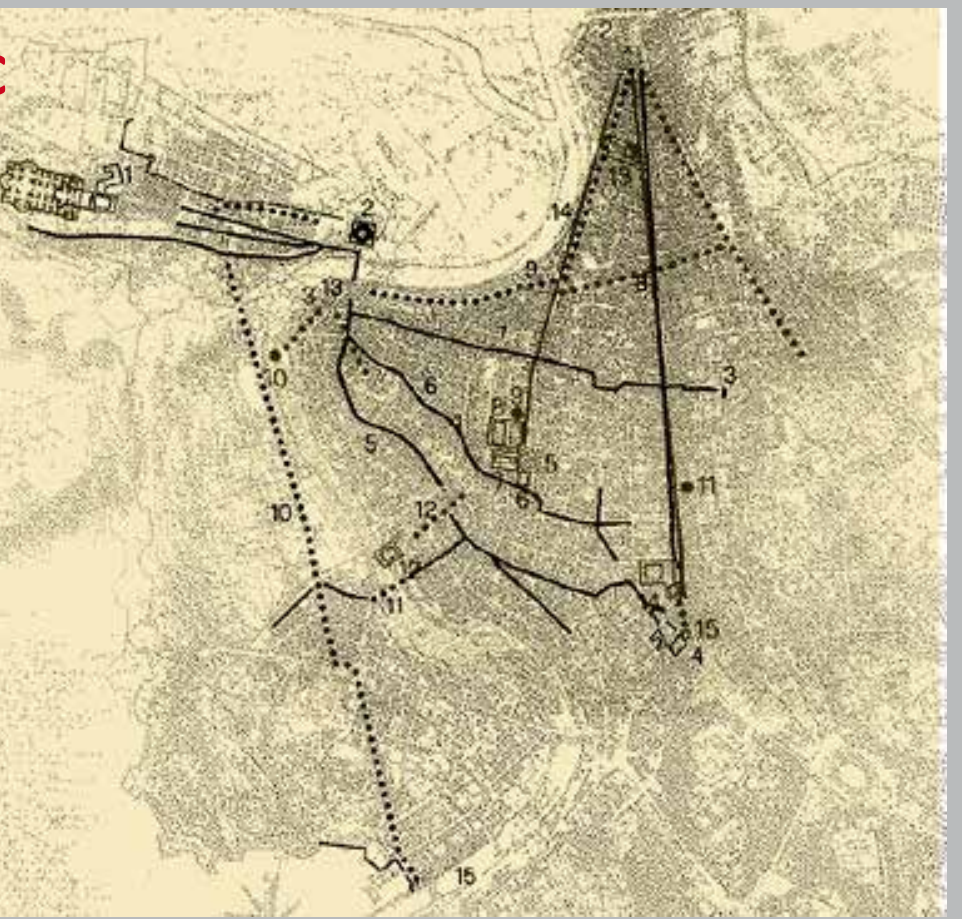

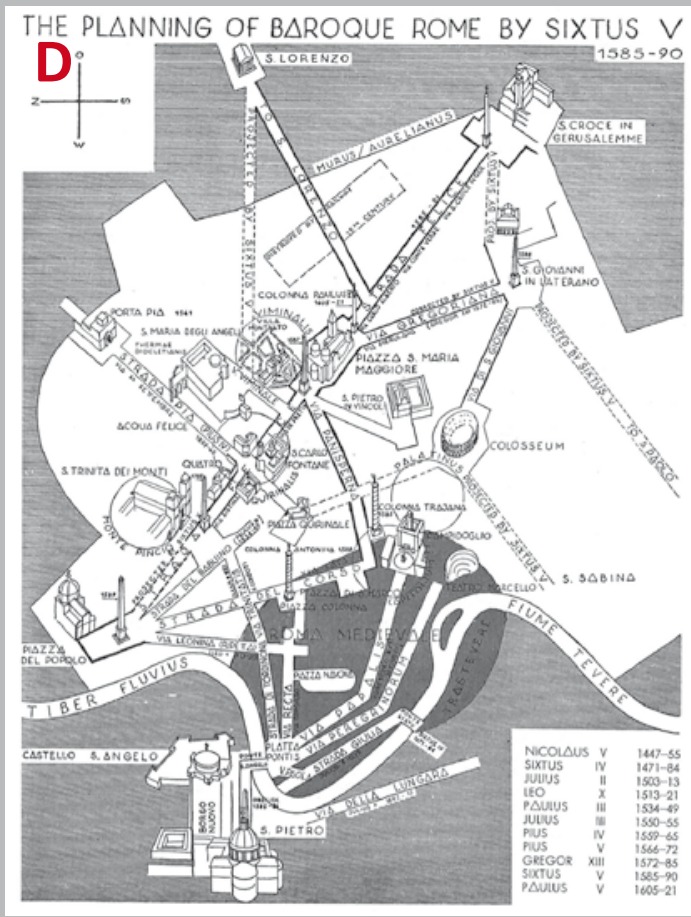

D Esquema de las intervenciones de Sixto $\mathrm{V}$ según Giedion (1941).

Una buena parte de los trazados se realizan fuera del 'casco antiguo' de la ciudad. 


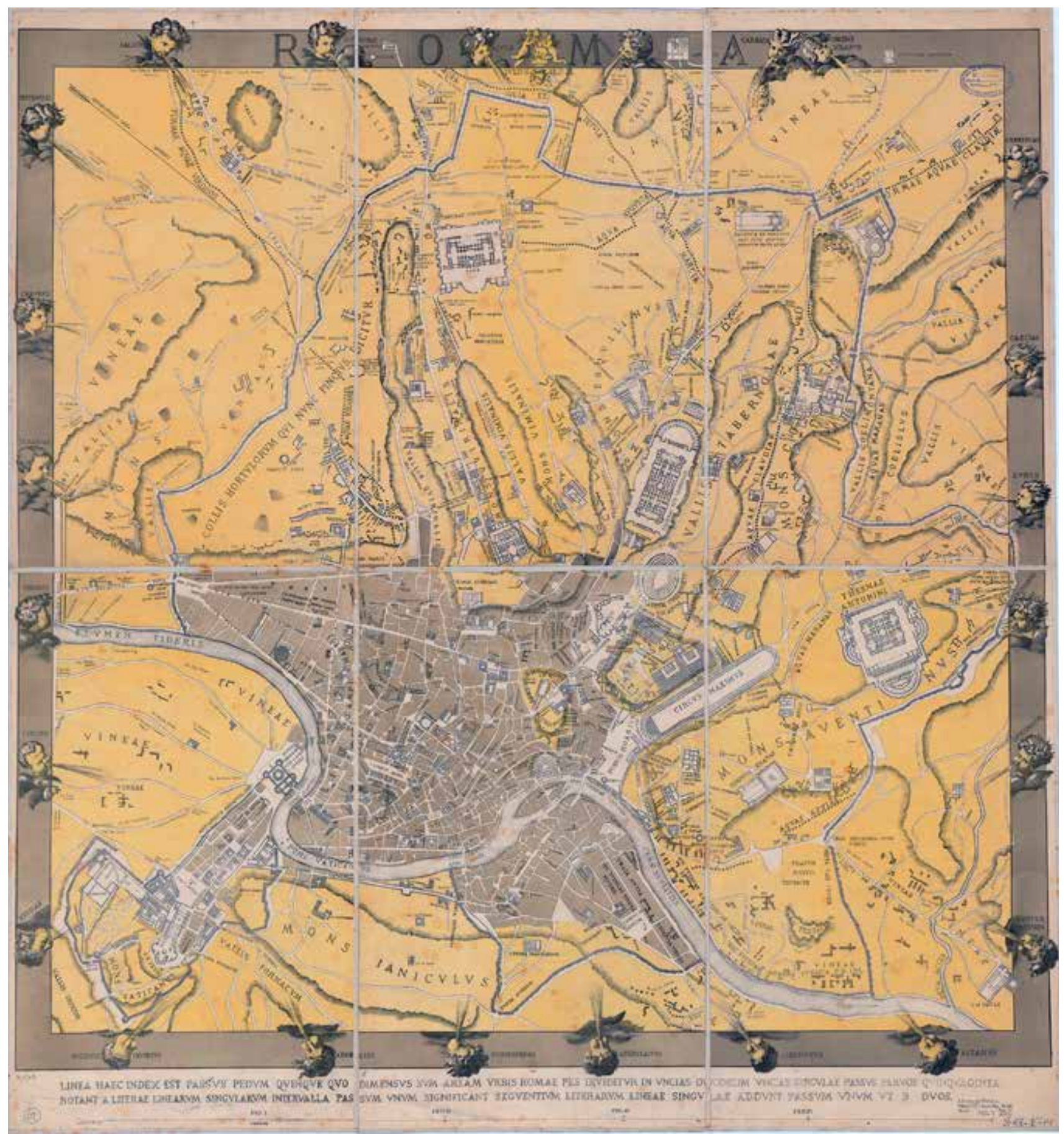

Plano de Roma de Leonardo Bufalini, 1551. En negro las murallas, en punteado los acueductos- C IGN (España)

En 1589, Fontana publica un libro en el que realiza un balance de sus actuaciones, básicamente del traslado e instalación de obeliscos egipcios y columnas romanas a diversos emplazamientos de la ciudad. Fontana explica que el Papa deseaba facilitar el camino para aquellos que, "animados por la devoción o la promesa, están acostumbrados a visitar con frecuencia la mayoría de los lugares santos de la ciudad de Roma, y en particular las siete iglesias tan celebradas por sus grandes indulgencias y reliquias" (Fontana 1589: 100-103). Para ello el Papa mandó trazar calles mucho más espaciosas y rectilíneas que facilitaban iniciar la ruta de las siete iglesias "a pie, a caballo o en carruaje desde cualquier punto de Roma", avanzando, prácticamente, en línea recta hacia las distintas iglesias. La apertura de estas calles tuvo un "coste realmente 
increíble", puesto que iban de un extremo a otro de la ciudad, e independientemente de las colinas o valles que atravesaran, se procedía:

"nivelando las colinas y el suelo de los valles, reduciéndolos a llanuras más suaves y a los lugares más encantadores, revelando asi las porciones más bajas de la ciudad, con sus más diversas perspectivas ". (Fontana 1589 pp. 100-103)

El más famoso es el camino llamado Felice - en honor del nombre laico del Papa, Felice Peretti-, que se origina en la Iglesia de la 'Santa Croce en Gerusalemme', pasa por la Iglesia de 'Santa Maria Maggiore' y continúa hasta 'Trinità dei Monti', desde donde desciende a 'Porta di Popolo', totalizando una distancia de 4 km, y permanece "recto como a plomada y lo suficientemente ancho como para dejar espacio para cinco carrozas emparejadas"(Fontana 1589: 100-103).

El trazado de la nueva ciudad, en terrenos prácticamente rurales, iba asociado a un proceso que hoy llamaríamos de regeneración urbana. Cuando Sixto V llegó al poder, encontró el tesoro público esquilmado y la ciudad llena de mendigos y parados. Abordó el problema construyendo refugios para los pobres y empleando a miles de trabajadores en su programa de construcción. El proyecto basado en la obra pública, permite dar trabajo a la legión de desempleados que pululaban por la ciudad. Se completa la infraestructura de acueductos (acueducto Aqua Felice) para llevar agua a una zona de Roma desabastecida desde la destrucción de los acueductos romanos; se crean nuevas plazas como complemento al trazado viario puntuándolas con iglesias, obeliscos y fuentes-como la zona de las 'cuatro fuentes' ubicadas en el cruce de la vía Felice y la vía Pía y con construcciones achaflanadas ${ }^{11}$. Un programa de fuentes que sería continuado por sus sucesores ya en el siglo XVII (Remesar 2020).

El Papa otorga privilegios a aquellos que se quieran instalar en las nuevas zonas.

"Su deseo ahora está listo para llenar la Ciudad, ya que estas calles están siendo frecuentadas por la población, y se están construyendo casas y comercios con gran profusión, en un lugar que antes era común que alguien se impidiera avanzar por las muchas curvas en las calles ". (Fontana 1589:100-103)

Además, el Plan de Sixto V incluye actuaciones relacionadas con el impulso económico de algunos sectores. Como relata Fontana, en la parte de la 'Piazza delle Terme'

"su Beatitud a su costa y para la conveniencia pública del pueblo, ha hecho construir un lavadero muy grande y bien ordenado, cubierto y rodeado de un enrejado de metal de doscientos noventa palmos de largo y doscientos cincuenta y un palmos de ancho, en medio hay dos recipientes para lavar con una gran cantidad de agua viva para quitar la suciedad, tales recipientes son de doscientos treinta y ocho palmos de largo y trece palmos y tres cuartos de ancho, el cobertizo tiene sobre la puerta la siguiente inscripción 'Lo hizo

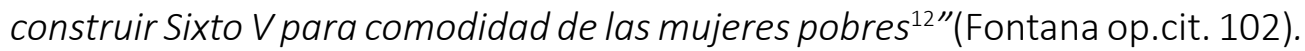

11 "El ángulo en el que se cruzan estas calles no es exactamente un ángulo recto, pero Domenico Fontana instaló allí cuatro fuentes, alimentadas por las aguas del Acqua Felice, con el fin de hacer desaparecer el desacuerdo y resaltar la importancia del cruce" (Giedion 1941).

12 Debemos recordar que, durante muchos siglos, seguramente hasta la instalación generalizada de 

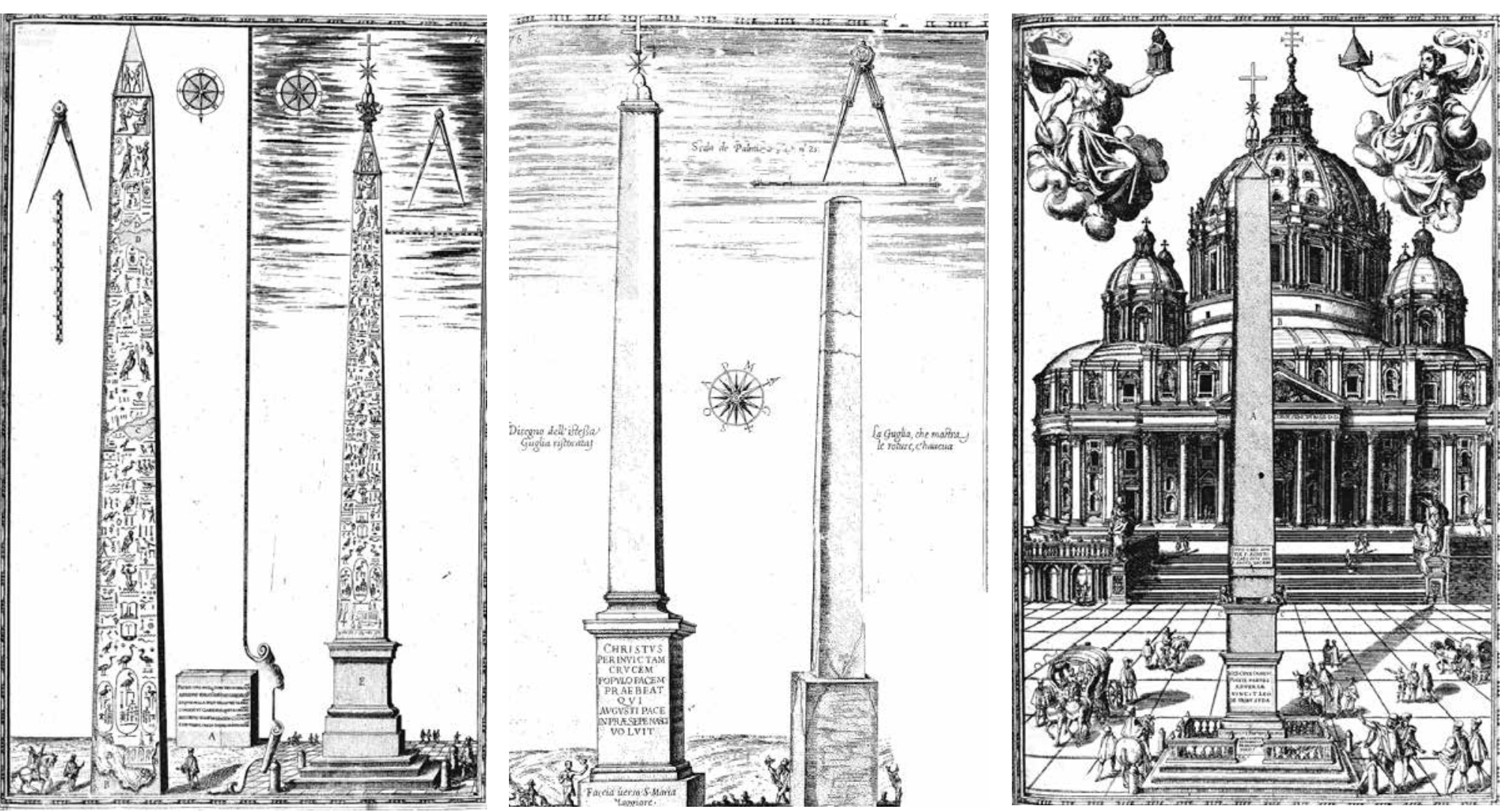

Re-significación de las columnas y obeliscos romanos. De izquierda a dercha, re-significación de los Obeliscos de la Plaza del Popolo, de Santa Maria Maggiore y de la plaza de San Pedro (dcha) según estudios de Fontana (1589).

romanas son intencionalmente re-significados. Como señala Fontana al describir las inscripciones de la columna antonina o de Marco Aurelio "Esta columna ha sido limpiada de cada impiedad" y por ello se coloca una estatua de San Pablo en su vértice "y se hizo una estatua de bronce de San Pablo, similar a la de San Pedro, de una altura de diecinueve palmos, toda dorada, y la altura de esta columna: ciento ochenta y nueve palmos con su pedestal, que es alto con sus decoraciones en la base, y la parte superior hace cuarenta y dos palmos, y veintidós palmos de ancho". (Fontana op.cit. p.99)

Mientras que San Pedro iría a presidir la columna Trajana.

El conjunto de operaciones urbanas llevadas a cabo por los Papas entre los siglos XV y XVI están basadas en la idea de que el centro de la ciudad - al mismo tiempo centro del mundo cristiano- es la basílica de San Pedro. En este sentido parafraseando el dicho, "todos los caminos conducen a Roma... y en Roma todos a San Pedro". Sin embargo, el crecimiento físico y humano de la ciudad, requiere de su ensanche realizado a partir de una idea simbólica que refuerza la centralidad de San Pedro. San Pedro se convierte en la joya de la corona papal, pero las siete iglesias serán las gemas que la acompañan en la tiara romana. 


\section{Lisboa}

"A principios del siglo XVI, Lisboa cambió profundamente su estructura urbana, física y simbólicamente, con la instalación de la corte junto al río, en un nuevo palacio real rápidamente construido fuera de la muralla, junto a los almacenes de las mercancías de Mina y India "(França, 1997 p. 7)

El espacio que actualmente ocupan la Baixa Lisboeta y el Rossio, fue, durante siglos, un estero por el que circulaban dos vías de agua y que se inundaba con la pleamar del río Tajo. La acumulación de lodos y restos, unida a la actividad antrópica, poco a poco lo fueron desecando. Así, la Olissipo, fundada en una colina, utilizó parcialmente esta zona como necrópolis, para instalar algunas termas, viveros de pescado e, incluso, un circo $^{13}$ (Vale \& Fernandes 1997). La Al-Ušbuna islámica, se desparrama por la colina en dirección al río, presidida por la medina y la alcazaba. Citando a Herculano, Júlio Castilho señalaba que Alfama era, en la época del dominio musulmán "el arrabal de la Lisboa gótica; el barrio aristocrático, bello y culto, cuando la Medina-Aschbouna se acurrucaba tristemente en su nido de piedra, en lo que más tarde se llamó "Ia Alcáçova", y hoy "el Castello"'” (Castilho, 1893, p. 130). Un barrio orientado al río y sus actividades. En su piedemonte, se ubicaba la Bab al Garb o Porta de Ferro, principal entrada de la ciudad. La muralla original se erigió, probablemente en el período tardo-romano (s. III-V) y, seguramente, fue aprovechada y reforzada en el período islámico (s.VIII-XII), sobre todo en el siglo X, después del saqueo de Ordoño III de León ${ }^{14}$.

Alfonso Henriques, primer rey de Portugal, con la ayuda de un ejército de 'cruzados' toma la ciudad en 1174 y le concede su Carta Foral en 1179. Como en otras ciudades medievales ${ }^{15}$, los arrabales crecen fuera de sus murallas, tanto hacia oriente como hacia occidente, ocupando las zonas inundables que se habían paulatinamente desecado con el tiempo. Tras la ocupación cristiana, Lisboa retoma su vocación comercial, reinstaurando las rutas comerciales con los reinos de taifas meridionales, con el norte de África y con el Mediterráneo, pero, sobre todo, inaugurando rutas atlánticas con el Norte de Europa, especialmente con Inglaterra, y las ciudades de la Liga Hanseática. Entre las mercancías del comercio de la ciudad estaban las especias y la seda; oro,

13 A pesar de la existencia de opiniones en contra entendemos que la descripción que hace Holanda, se refiere, precisamente a un circo: "a través de conductos subterráneos, horadando muchos cerros y con mucho gasto y trabajo, [...] alli entre dos peñascos muy altos de dos cerros hicieron un muro muy ancho y fuerte que represaba el agua de un valle en un estanque o laguna en la que dicen que trajeron, para su entretenimiento, galeras y bateles, como se puede ver hoy en día en la pared y en el sitio que era posible"(Holanda 1571), aunque es cierto que Holanda con parezca tener muy claro este concepto. 14 La muralla que defendía Al-Ušbuna habría tenido aproximadamente $1.250 \mathrm{~m}$ de largo en su extensión total, de 2 a 2,5 m de espesor y cubría un área de aproximadamente 15,6 hectáreas (Vieira da Silva, 1940). Por lo tanto, el área total de Al-Ušbuna, en su apogeo a finales de siglo. XI, serían aproximadamente 30 hectáreas, sumando al área intramuros antes mencionada dos arrabales, uno oriental y otro a occidente ocupando parte del antiguo estero, en con un área combinada de 15 hectáreas. Se estima una población del orden de los 20 a 30.000 habitantes, siendo comparable a los grandes puertos de Malaka-Málaga- y Al-Mariyya-Almería- (Torres, 1995)

15 Esta evolución de los arrabales la analizamos, en el caso de Barcelona, en la primera parte de este trabajo (Remesar 2021, p. 47-58) 


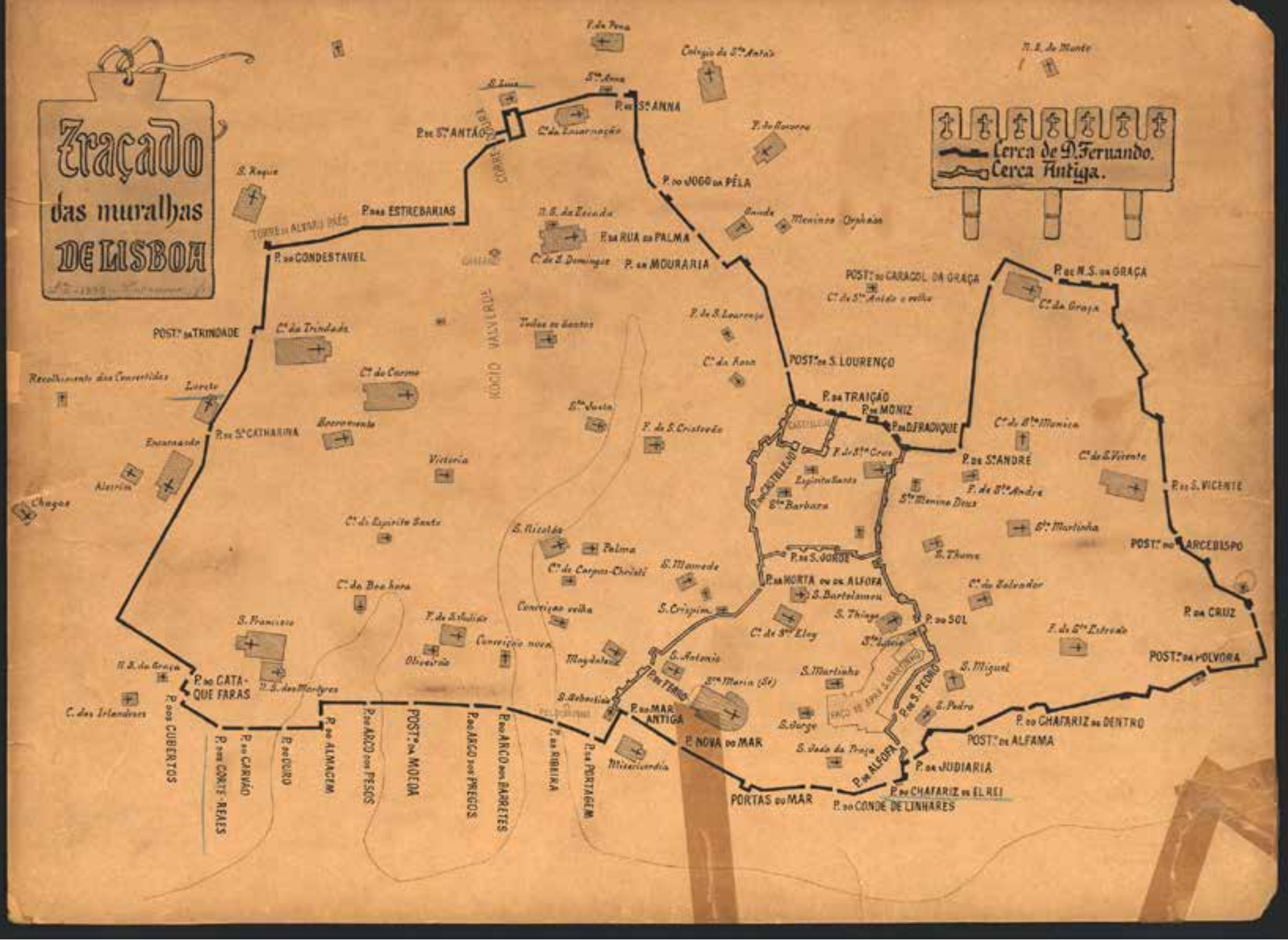

Esquema de las murallas y puertas de Lisboa. En claro la Cerca Velha musulmana. En negro la muralla fernandina. No se aprecia la muralla de D. Dinis. Planta de 1892 por E. Casanova Traçado das Muralhas de Lisboa. (C) BNP. https://purl.pt/1524

marfil, arroz, carbón, almendras y azúcar adquiridas a los musulmanes; aceite, sal, vino, corcho, miel y cera que producía Portugal y los textiles de lana, lino; estaño, hierro, colorantes, ámbar, armas, pieles y productos artesanales que provenían del norte de Europa. Se crearon unos astilleros para la construcción de barcos, siendo esencial la ayuda de la armada para la protección del comercio, especialmente en la lucha contra los piratas sarracenos. Se innova en la construcción de barcos, en una síntesis de conocimientos cristianos, vikingos y árabes se diseña la carabela (la primera referencia es de 1226), el primer navío atlántico. A las profesiones ligadas a la navegación como la carpintería y la marina, se les dan privilegios y protección, incluyendo la creación en Lisboa de una institución judicial propia, el alcalde del Mar (1242). Sobre las rutas comerciales ver la primera parte de este trabajo (Remesar 2021 p. 50)

La ciudad se convierte en una plataforma de intercambio entre el comercio atlántico y el comercio mediterráneo. La posición central de la ciudad en la geografía portuguesa, 


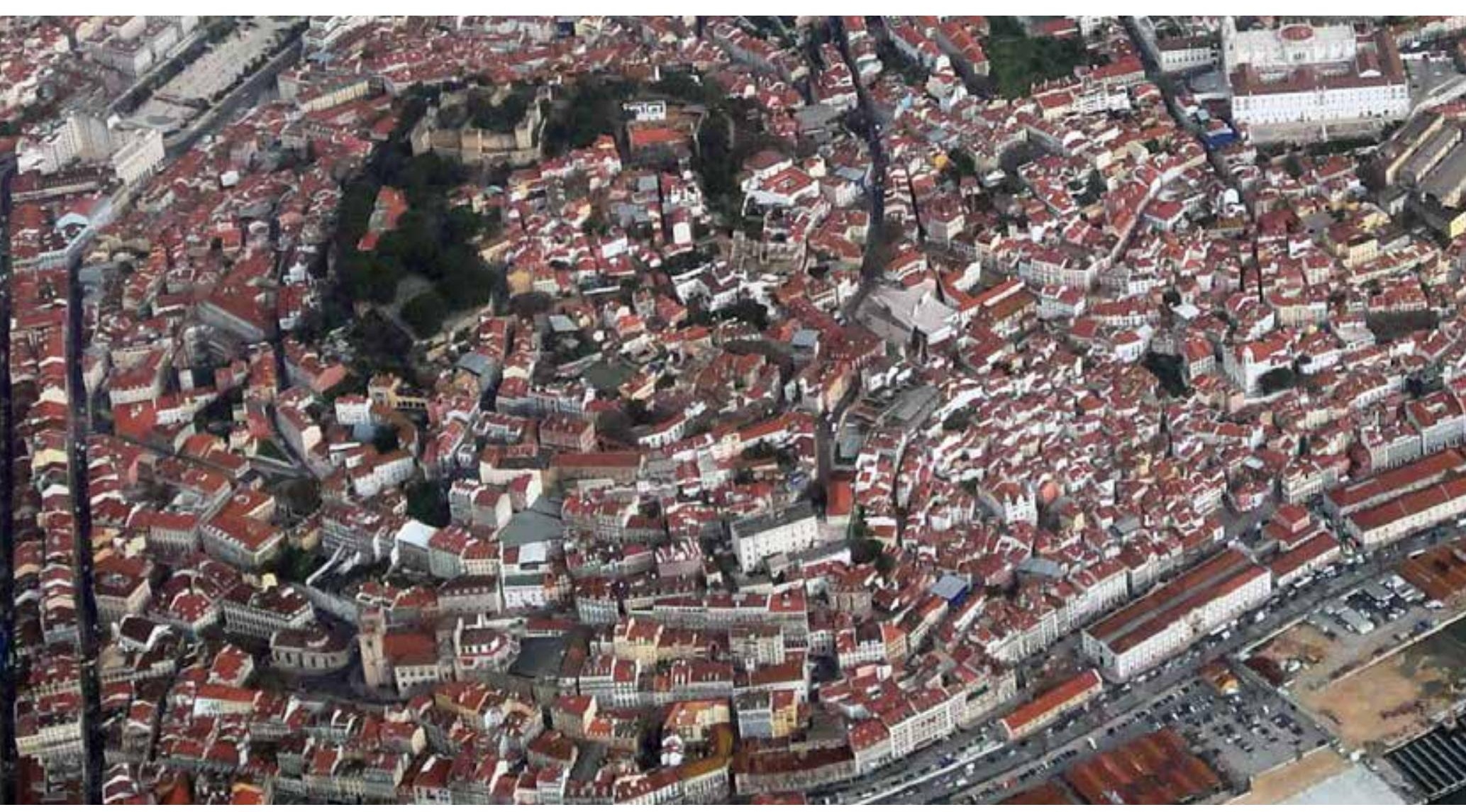

se refuerza cuando Alfonso II, tras la conquista del Algarve, traslada desde Coímbra, la Cancillería del Reino, es decir la corte, los archivos y la tesorería de Portugal, convirtiendo Lisboa en la capital del reino. La corte se instaló en lo alto de la colina, en los Paços da Alcáçova islámica.

Señalaba Torres Balbás que las más importantes ciudades hispanomusulmanas estaban formadas por un núcleo central rodeado de muros, llamado madina-medina en castellano, en el que se hallaban la mezquita mayor, la alcaicería -kaisariya-y el comercio principal, y por una serie de arrabales -rabad, en singular-, relativamente autónomos, apenas coordinados con aquélla.

"Los últimos estaban también casi siempre amurallados y su cerca unida a la de la medina. Cada uno de los arrabales y aun de los barrios más extensos formaba, a semejanza de la medina, como una pequeña ciudad independiente, organizada en torno a una reducida mezquita, con sus zocos, tiendas, alhóndigas, baños y hornos". (Torres-Balbás, 1954 :9-10)

El trazado de estas ciudades hispanomusulmanas se caracterizaba por la existencia de unas pocas calles -transversales o radiales- de trazado sinuoso, que enlazaban las entradas o puertas más concurridas del recinto amurallado. En el caso de existir arrabales extramuros, solían prolongarse por ellos. De esas calles radiales arrancaban otras secundarias, angostas, que se quebraban y torcían a cada paso. Y de éstas, a su vez, nacían numerosos callejones sin salida, que penetraban profundamente en las extensas e irregulares manzanas para dar ingreso a las viviendas, ramificándose laberínticamente. El mismo trazado callejero, simplificado y reducido a menores proporciones, se repetía en cada uno de los barrios y arrabales de alguna extensión, garantizado, de este modo, la serventía de paso. 


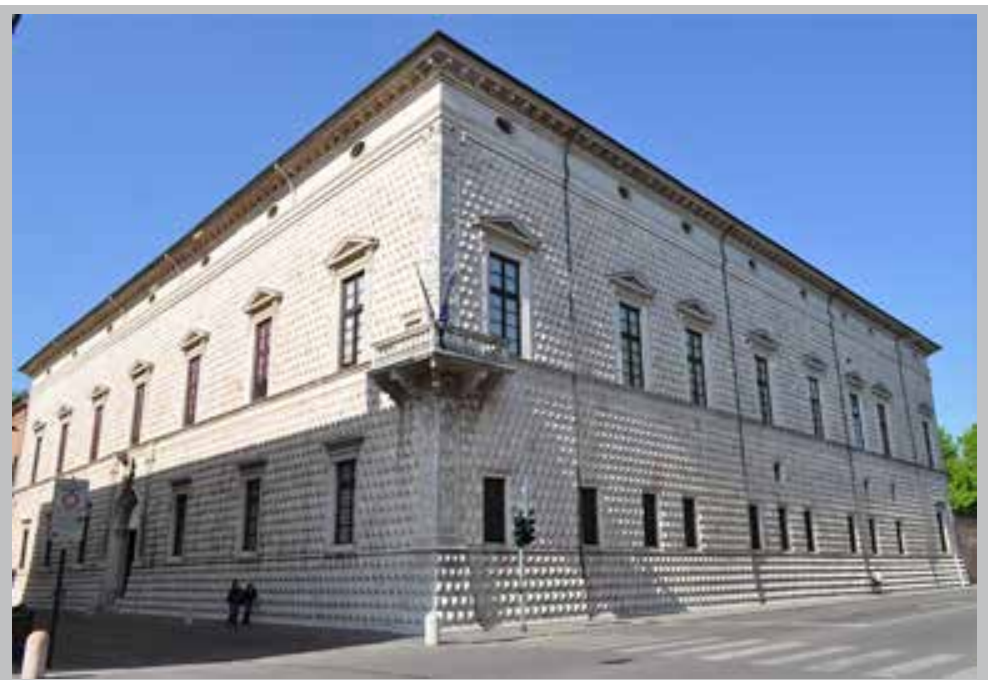

Palazzo dei Diamati (Ferrara) 1493-1503. realizado por Biagio Rossetti

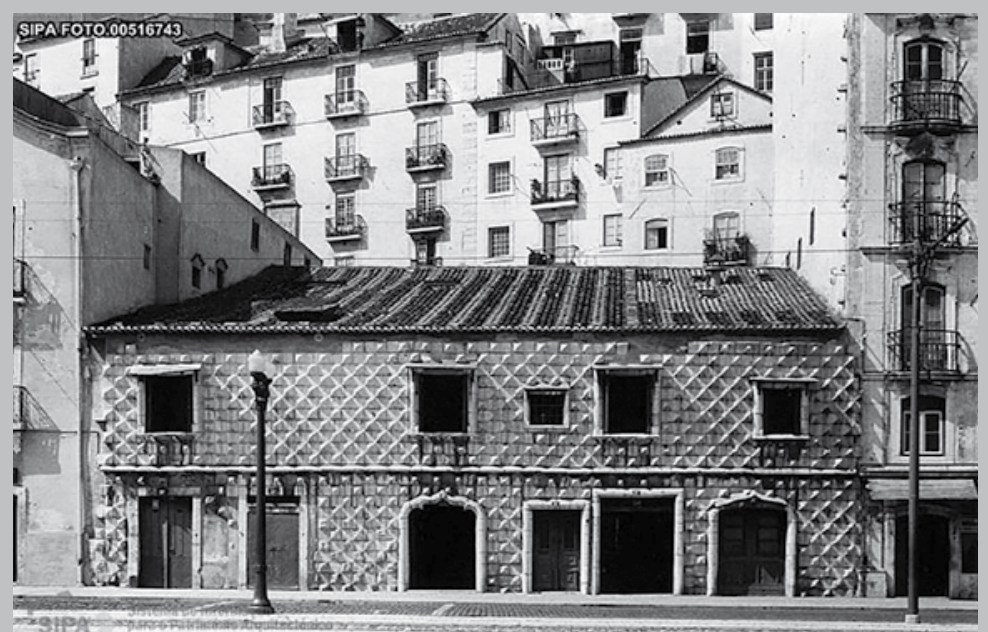

Casa dos Bicos a inicios de 1960 CSistema de Informação para o Património Arquitetónico

\section{Influencia de los ejemplos}

\section{Casa de Brás de Albuquerque, conocida como Casa dos Bicos (Lisboa) 1523}

La Casa dos Bicos fue construida por Brás de Albuquerque, un cortesano cultura humanista. En 1521 Brás de Albuquerque formó parte del séquito real que condujo a la infanta D. Beatriz, hija de D. Manuel, a Italia para su matrimonio con el duque Carlos III de Saboya; allí entró en contacto con los modelos de la arquitectura renacentista italiana. A su regreso a Portugal, hacia 1523, mandó construir un edificio inspirado en los palacios italianos de diamantes, atribuyendo algunos autores la obra al arquitecto real Francisco de Arruda.

La estructura original resultó gravemente dañada por el terremoto de 1755. La fachada principal, que daba a la actual Rua Afonso de Albuquerque, se derrumbó así como los dos pisos superiores de todo el edificio. En 1772 el edificio fue parcialmente reconstruido, pero la estructura del siglo XVI sufrió una alteración irreparable. A lo largo del siglo XIX, la casa sufrió las más variadas vicisitudes, siendo utilizada como almacén de bacalao durante décadas. En la planta baja se abrieron puertas de marco regular de diferentes dimensiones. En $1910 f u e$ declarada Monumento Nacional.

Hacia 1960, el Ayuntamiento de Lisboa adquiere la Casa, contratando en 1968 a Raul Lino para realizar un proyecto de adecuación del espacio para museo. Sin embargo, la obra se pospuso y sólo en 1981, con motivo de la XVII Exposición Europea de Arte, Ciencia y Cultura, promovida por el Consejo de Europa, se decidió recuperar la Casa dos Bicos para instalar el núcleo de aquella exposición "La dinastía Avis y la Europa del Renacimiento" que tuvo lugar en 1983 (Arq. Manuel Vicente y Daniel Santa Rita). Se adaptó el espacio a las nuevas funciones museológicas, agregando los dos pisos que se habían perdido con el terremoto. La fachada fue reconstruida según antiguas imágenes de Lisboa que muestran la estructura original de la casa de Brás de Albuquerque.

De planta rectangular, el edificio se distingue por su singular fachada, en la que el aparato renacentista con punta de diamante-que dio origen a la denominación popular de Casa dos Bicos- se combina con ventanas contemporáneas inspiradas en el lenguaje decorativo manuelino. La distribución irregular da ritmo a la fachada. La disposición original del espacio interior se modificó profundamente para albergar los centros de museología. Entre 1986 y 2002 el edificio albergó la extinta Comisión Nacional para las Conmemoraciones de los Descubrimientos portugueses. Actualmente, es la sede de la Fundación José Saramago. 
convento de San Domingo que estará en el origen de uno de los lugares emblemáticos de Lisboa: el Rossio.

El rey Dionisio I, casado con Isabel de Aragón y creador de la Orden de Cristo, introdujo reformas judiciales, decretó la lengua galaico-portuguesa como lengua oficial de la corte, y creó el 'Estudo Geral' (1290) en Lisboa, germen de la primera Universidad portuguesa ${ }^{16}$, prosiguiendo un sistemático aumento del centralismo regio. En el marco de la actividad mercantil marítima, funda en 1312 la marina portuguesa y la pone a cargo de Manuel Pesanha (Emanuele Pessagno), marino genovés, nombrado primer almirante de Portugal.

La consolidación de Lisboa como capital del reino y su crecimiento poblacional, comercial y residencial en la actual Baixa, la convierte, como señala Carita (1999), en centro económico y portuario de la ciudad, pero, también y en parte, en centro administrativo al desplazar la Aduana, la Casa dos Contos- el primer órgano de organización y control de los ingresos y gastos de Portugal, reuniendo todos los documentos relativos a los ingresos y gastos del Estado desarrollando una misión similar a la de su sucesor moderno, el Tribunal de Cuentas-, la Casa de Ver-o-Peso- una institución de la ciudad y del reino, en la que las mercancías que entraban por el puerto eran pesadas y tasadas mediante el respectivo impuesto, actuando a modo de aduana- o los Cambios, al pie de las Portas de Ferro.

Como medida de protección de estas instituciones y de la ciudad, en 1294, el rey, ordena la construcción de un tramo de muralla - que quedará inconcluso- entre la antigua cerca velha y el piedemonte de la colina de San Francisco, justo frente al río Tajo. Frente a la muralla se instalan las atarazanas afianzando, en parte, un nuevo puerto para Lisboa. La construcción de la muralla formaba parte de los trabajos de reestructuración urbana que implicaron una actividad de destrucción creadora con la remodelación de la plaza de los Açougues - en la que estaba instalado el mataderomediante la demolición de algunos edificios, para dar lugar a la plaza llamaba Largo do Pelourinho (picota). "Esta plaza, medía aproximadamente $50 m \times 45 m$ de área, grande para la época, y estaba cerca de la Rua Nova dos Ferros" (Vieira 1940) unas dimensiones enormes para la época. Implicó, también, la ampliación de la Rua Nova [dos Mercadores], para cuya remodelación se emplea la técnica del 'cordeamento', es decir, el trazado a cordel de los nuevos solares y edificios. La Rua Nova, eje paralelo y abierto al río, ya existía en el reinado de D. Dinis que plantea su regularización y

16 De modo intermitente, con traslados entre Coímbra y Lisboa, la Universidad se mantuvo en Lisboa entre 1290 y 1537. Felipe I funda en 1594 el Aula do Risco. En 1759 se funda el aula de Comercio a la que seguirá el aula de 'Desenho de Figura e Arquitectura Civil'. La escuela de cirugía se creará en 1825 y cinco años después la Escuela Veterinaria. En 1836 se crea la 'Academia de Belas-Artes' de Lisboa a partir da 'Aula de Desenho de Figura e Arquitectura Civil'; el 'Conservatório de Artes e Ofícios' de Lisboa y la Real 'Escola de Cirurgia' de Lisboa se convierte en 'Escola Médico-Cirúrgica' de Lisboa, junto a la Escuela de Farmacia a ella anexa. En 1837 se creará la Escuela Politécnica de Lisboa,y no será hasta 1911 que se refunde la Universidad de Lisboa 


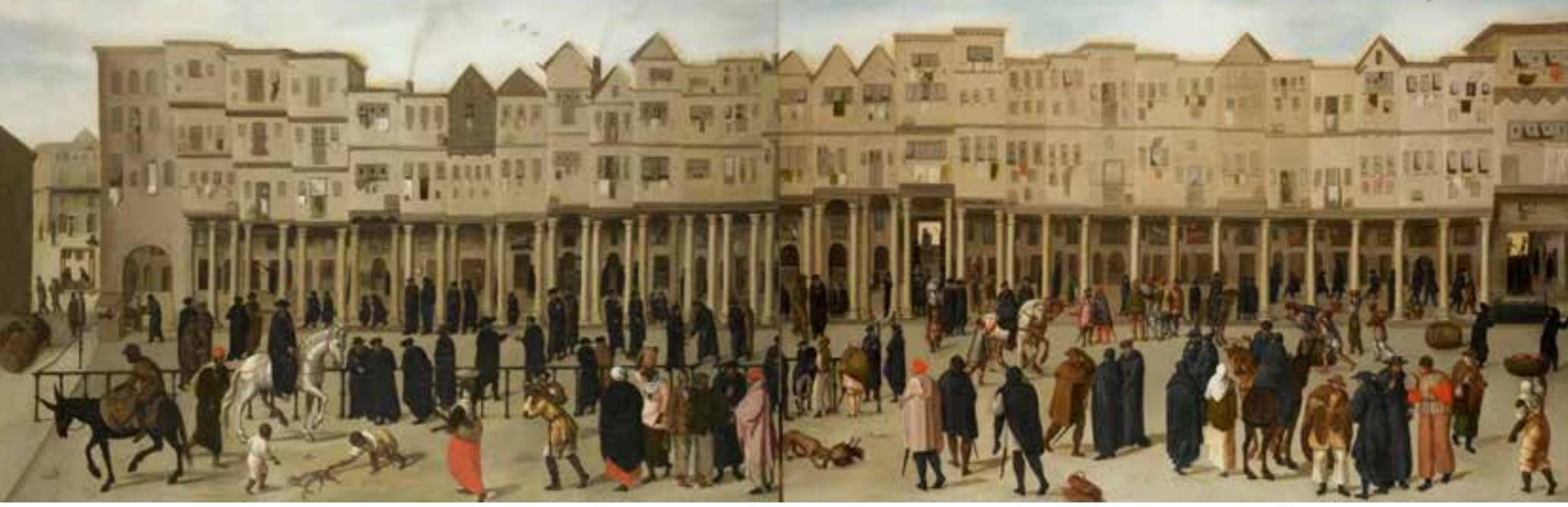

Rua Nova dos Mercadores, em Lisboa. Autor anónimo, c. 1570-1590. Londres, Kelmscott Manor Collection - Society of Antiquaries of London. Ref: Trindade 2016

ampliación en 1294, empresa que obligó al derribo de las casas, para que la calle tuviera 8 brazas de anchura. Posteriormente se abrieron varias calles en este lugar.

El nombre, Rua Nova dos Ferros, proviene de la zona en que se reunían los cambistas que estaba delimitada por una valla de hierro. Las primeras noticias del proyecto de pavimentación - con piedra de Oporto- de la Rua Nova de Lisboa aparecen en una carta del João II, en noviembre de 1482, en la que determina, como obra preliminar, la ejecución de una planta "pintada en papel " de 6 metros, con el fin de estudiarlo mejor y emitir su opinión (Trindade 2016).

Estas trasformaciones urbanas implican la consolidación del crecimiento de Lisboa hacia occidente, hacia las colinas de San Francisco y del Carmo por ejemplo con la instalación de los Estudos Gerais- con el desarrollo del Arrabal de la Pedreira en el que, al entender de Helder Carita, aparece un sistema de parcelación organizado a partir de 'calles directas' (ruas direitas) al que se añadirán sus travesíos (travessa) o calles secundarias, configurándose un modelo que se desarrollará en el siglo posterior (Carita, 1999).

La dinámica urbana de Lisboa, impulsa al rey Fernando I - tras del asalto y saqueo infligido a la ciudad en 1373 por el ejército del rey Enrique II de Castilla- a la construcción de un nuevo recinto de murallas que engloba tanto los nuevos arrabales como las antiguas murallas incluida la inconclusa muralla del rey Dionisio. La nueva muralla genera un nuevo proceso de crecimiento urbano: un espacio nuevo para la aparición de una nueva calle (rua da Pastelaria) paralela a la Rua Nova [dos Mercadores] encaja entre las dos murallas. Se introducen mejoras en la pavimentación e iluminación de las calles.

"Fue en un regimiento de policía detallado dado por el rey Fernando I a la ciudad de Lisboa, en su carta del 12 de septiembre de 1383, que (entre otras medidas encaminadas a prevenir el latrocinio) se establecía que, según determinaran los buenos hombres, se colocasen en ciertas calles, puntos de luz (antorchas, velas, teas) para alejar a los malhechores" (Castilho 1890 p 166) 
Tras la muerte en Fernando I y la guerra con Castilla, accede al trono Juan I, Gran Maestre de la Orden de Avís, iniciador de la expansión ultramarina de Portugal con la conquista de Ceuta (1415), de Madeira (1418), actividad, en parte, impulsada por su hijo Enrique, fundador de la escuela de navegación de Sagres que, según alguna tradición historiográfica, fue el fundamento de colonización portuguesa de las Azores (desde 1426) o la costa occidental de África ${ }^{17}$ con un nuevo tipo de barco, la carabela, bien acondicionada para la navegación oceánica. Juan I demostró un gran interés por el desarrollo urbano de Lisboa. Traza la rua da Padaria (1393) junto a las Portas de Ferro, una calle 'directa' entre la zona de murallas y la catedral. Estas calles directas pretenden romper la estructura de núcleos aislados de la ciudad musulmana. En el interior del recinto amurallado que conserva un carácter eminentemente rural, facilita la construcción de algunos nuevos arrabales como el barrio de las Puertas de Santa Catarina, construido sobre los terrenos comprados a la familia del almirante Pessanha.

Emerge un nuevo centro: el Rossio

"Fueron necesarios siglos, y muchos, para transformar estos terrenos mal usados en una plaza afable y ornamento urbano; pero es innegable que, con el paso de los años, el Rossio de Lisboa se ha convertido en una magnífica plaza, superando por la grandeza y nobleza de sus construcciones a todas las demás plazas de la capital; hasta el punto de afirmar en su tiempo Luiz Mendes de Vasconcelos, con ese énfasis propio de los escritores peninsulares, que no se conoce en otra ciudad otra de semejante tamaño, rodeada de casas nobles y grandes templos"(Castilho 1890 p. 29).

Desde la conquista de Lisboa, el 'mercado' (Chão da Feira) estaba situado en la zona del castillo, en la puerta de San Jorge. En 1273, el rey Alfonso III ordenaba que el mercado no siguiera teniendo lugar en las casas del rey, cerca de la Alcáçova, pero permitía su celebración donde mejor le pareciera al Consejo de la Ciudad, y un día a la semana. Recordaremos que en 1242 se fundó el convento de San Domingo. En su entorno, aquel soberano donó a la ciudad muchas tierras alrededor del monasterio, que en aquella época eran tierras baldías, que el pueblo usaba sin haber dueño particular de ellas. Sería en estos terrenos comunes que emergería el actual Rossio. (Castilho 1890)

Hacia 1311, el rey D. Denis intervino en la explotación, y también en la ampliación de Rossio de Lisboa. Como señala Castilho (op.cit), los consejos municipales estaban muy celosos de la propiedad de estos terrenos comunes, tal que no consintieron la intrusión en tales lugares públicos de los propios soberanos. Así, por ejemplo, la

17 La Escuela de Sagres, fue una agrupación de personalidades científicas y técnicas ligadas a la navegación oceánica portuguesa del siglo XV, articulada entorno al infante Enrique, apodado el Navegante. Aunque del cercano puerto de Lagos salieron numerosas expediciones de exploración, saqueo y colonización hacia las costas africanas e islas atlánticas, la existencia de la Escuela ha sido puesta en duda por numerosos historiadores que, no encontraron respaldo arqueológico ni documental para justificar su existencia, y la consideran un mito de la historia portuguesa. Los historiadores están de acuerdo en que al menos desde la muerte del infante Enrique (1460), el centro impulsor de los descubrimientos portugueses fue Lisboa. 


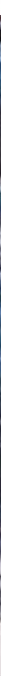

Rossio s. XVIII. Panel de azulejos de la primera mitad del siglo XVIII, procedente de un taller lisboeta, que representa la fachada del Hospital Real de Todos-os-Santos, frente a Rossio. En el lado izquierdo está representada la Fuente de Neptuno, que fue emparejada con la del Terreiro do Paço, dedicada a Apolo. Este panel constituye el elemento iconográfico más completo para el estudio del Hospital Real de Todos-os-Santos. Construido en 1492 por D. João II, fue terminado en los primeros años del siglo siguiente, ya bajo el reinado de D. Manuel y con una clara visión del estilo manuelino en la fachada del Hospital. Fuente: Museu da Cidade. Lisboa

Câmara de Lisboa entabló pleito con el Sr. D. Dinis, para impedirle construir edificios, como parece que había hecho construyendo carnicerías, carpas, herrerías, almacenes y casas. Esta demanda terminó, en 1323, con un acuerdo entre los litigantes, pagando el Rey a la ciudad el tributo llamado 'jugadas', y declarando que nunca se extendería sobre estos baldíos de la ciudad.

El Rossio demoró un siglo en convertirse en una 'plaza'. En el primer tercio el siglo $\mathrm{XV}$, los martes se celebraba el mercado y, en este periodo, se construyó el Paço dos Estaus (palacio para alojar visitantes importantes a la ciudad e incluso residencia real en algunos momentos), una idea que se remonta al rey Eduardo I pero que acabaría realizando el infante Pedro de Portugal.

En la época de las Cortes (1439) entre otras libertades que el Príncipe (D. Pedro, regente) en nombre del Rey (D. Alfonso V) concedió a los lisboetas, estaba que en esa ciudad no había pensiones, y que se construyera el Estáos no Rocio, donde el rey pudiera albergar su corte, que entonces no se componía de tanta gente inútil y ociosa como lo fue más tarde, cuando los reyes trajeron más hombres de los que necesitaban, con lo cual el la corte fue más avergonzada que honrada._Duarte Nunes, Chron. d'el-Rei D. Affonso V, cap. VIII.(Citado por Castilho Lisboa Antiga vol 10: 37)

Tiempo después, a este palacio, en cuya planta baja se situaban las caballerizas reales, siguieron otros edificios residencia de hidalgos o el Palacio Almada, llamado también de la Independencia (1509) y, ya a finales del siglo XV, entre 1492 y 1501, el rey Manuel I manda edificar otro de los 'elementos primarios de urbanización' (Rossi 1968): el 'Hospital Real de Todos-os-Santos'. El maestro arquitecto Diogo Boitaca, -autor de la torre de Belém con Francisco de Arruda y de la primera fase del Monasterio de los Jerónimos- fue el responsable de dirigir la construcción del Hospital, aunque su suegro Mateus Fernandes (responsable principal de la construcción del monasterio 


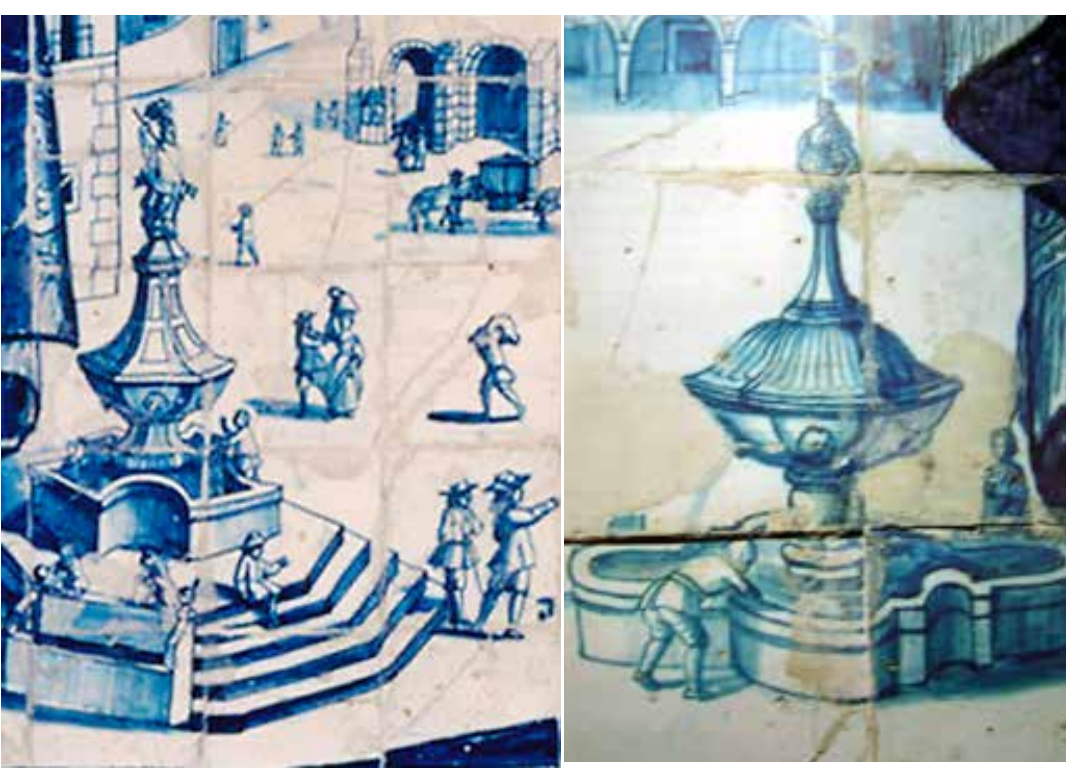

C A R T A IN VITATORIA NEPTUNO DO ROCIO, APOLLO DOTERREIRO D O P A C, O, Em gue o comvida para que vá ver a fefta de Tou. nos, que je fas na Praça do Rocio.

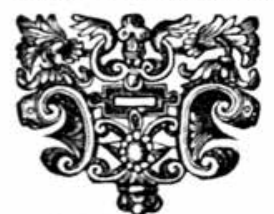

L I S B O $A$, Con todas as licengas necefariast. Anno 1755 :
RELACAÖ A $\underset{\text { D TER REI RO Do PAC, } O}{\mathrm{P}} \mathrm{L}_{\mathrm{P}} \mathrm{O}$ contra o

N E P T U N O D O R O C I O

com o con/entimento que o mefino apollo fez ao sal Neptuno de lograr o recreyo das feffas dos Touros.

O B R A N O V A M E T TE

EXPOSTA AO PUBLICO para que todo obicho vivente veja o genero de amarguras, que padece 0 pobre Apolio.

需(1)

L I S B O A :

Anno de MDCCLV.

Com todas as hicenseas sefjariat.

Detalle del Chafariz do Neptuno (izda) y del de Apolo (dcha) situado en el Terreiro do Paço. Am-bas fuentes "establecen una estrecha relación" que se traducirá en ambales diatribas entre ellos, como podemos ver en los pasquines.
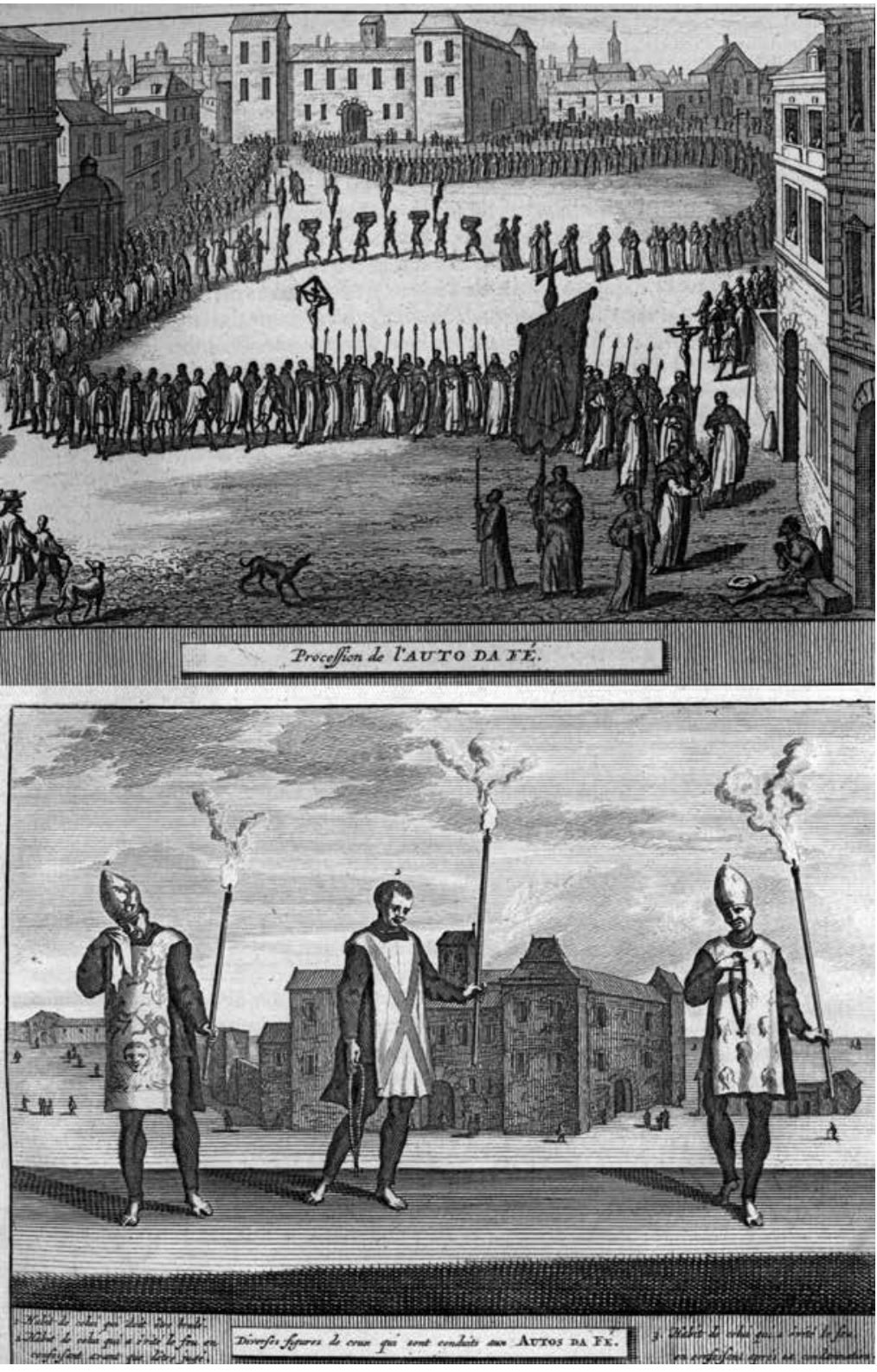

La plaza del Rossio y el Paço dos Estaus en dos ilustraciones del libro "Les delices de l'Espagne et du Portugal" de Juan Álvarez de Colmenar (1707) de Batalha) fue el diseñador.

El edificio se divide en cuatro alas, con agradables jardines; Tiene treinta y cuatro galerías, que, a su alrededor, conducen a magníficas viviendas, donde se pueden ver, limpios y ordenados, los comedores, los dormitorios, con camas y ropa blanca. [...] Hay casas o instalaciones al lado del hospital para las diferentes categorías de empleados; tesoreros, abogados, médicos, farmacéuticos y demás empleados, siempre dispuestos a socorrer a los enfermos, en cualquier contingencia, ya servirles, día y noche, con diligencia y cariño. [...] Frente a la puerta de entrada, hay una gran explanada, flanqueada por hermosos edificios, desde donde parten los valles de Santo Antão y Mouraria. (Góis 1554: 54-55)

El inicio de la construcción del Hospital Real de Todos os Santos tuvo lugar en mayo de 1492, colocándose la primera piedra en presencia del rey João II y se inauguró nueve años después, ya en el reinado de D. Manuel I. Aunque en 1520 el rey Juan III se instala en el Paço dos 


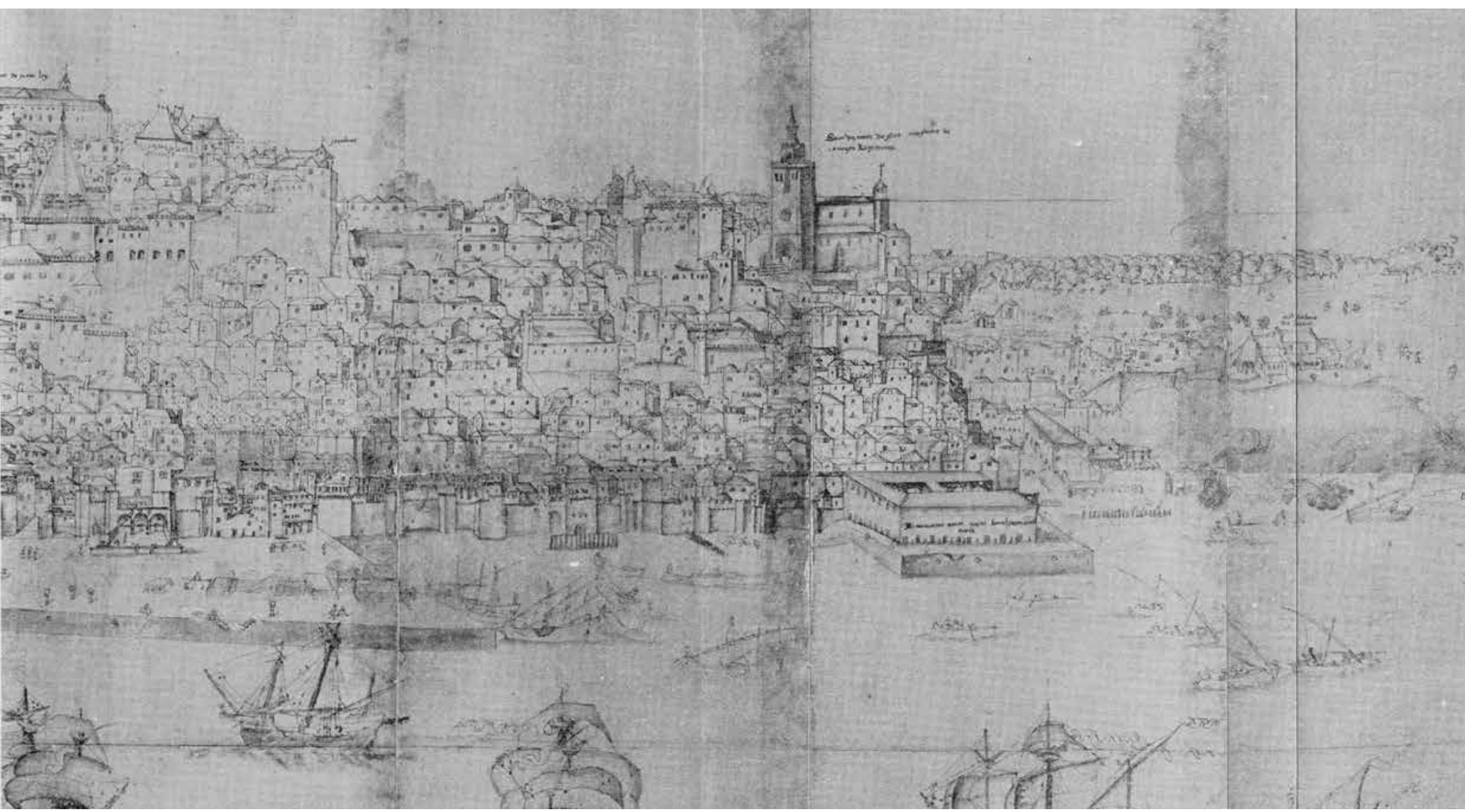

Fragmento de la Panorámica de Lisboa de autor anónimo depositado en la Biblioteca de la Universidad de Leyden. Fuente: Moita 1983

Como señala Helder Carita (Carita 1990), aparte de una serie normas sobre alineaciones de calles y la creación de algunas de ellas, para conseguir conectar las áreas centrales de la ciudad, la decisión más importante fue la de trasladar la sede de la corte desde la alcazaba musulmana al Paço da Ribeira frente al Tajo, en el sitio abierto llamado Terreiro (plaza) do Paço, donde todo era playa , y con gran trabajo y gasto se terraplenó para ganar espacio al mar, quedando encuadrado por el Paço (Palacio), el frontal de edificios levantados frente a la muralla fernandina, edificios que, en el contexto del descubrimiento de la ruta hacia la India y del monopolio portugués del comercio de especias, se fueron construyendo destinados al control de los productos importados desde África (Casa de Ceuta, Casa da Mina e Guiné) y los edificios destinados a almacenes y aduana.

Tras la llegada de Vasco de Gama y el descubrimiento de la ruta hacia la India, el rey Manuel I decide trasladar la sede de la corte a la ribera de la ciudad. Palacio al que se traslada la corte en $1503^{18}$. El recinto del palacio se levantó sobre los antiguos almacenes de la Casa da Mina. De forma rectangular, sobre una serie de soportales, incluía una Capilla Real, un almacén de armas y, posteriormente, la Casa da India (nova) con sus cuatro mesas u oficinas generales: la Mesa de la Pimienta, la Mesa de los Paños, la Mesa de las Drogas, la Mesa de las Armadas. El Palacio estaba presidido por una torre y finalizaba en un torre-fortaleza, sobre el río Tajo, diseñada por Diogo

18 Curiosamente, el Paço da Alcáçova (sede de la Corte hasta el momento) quedó dañado por un terremoto ocurrido en 1531 


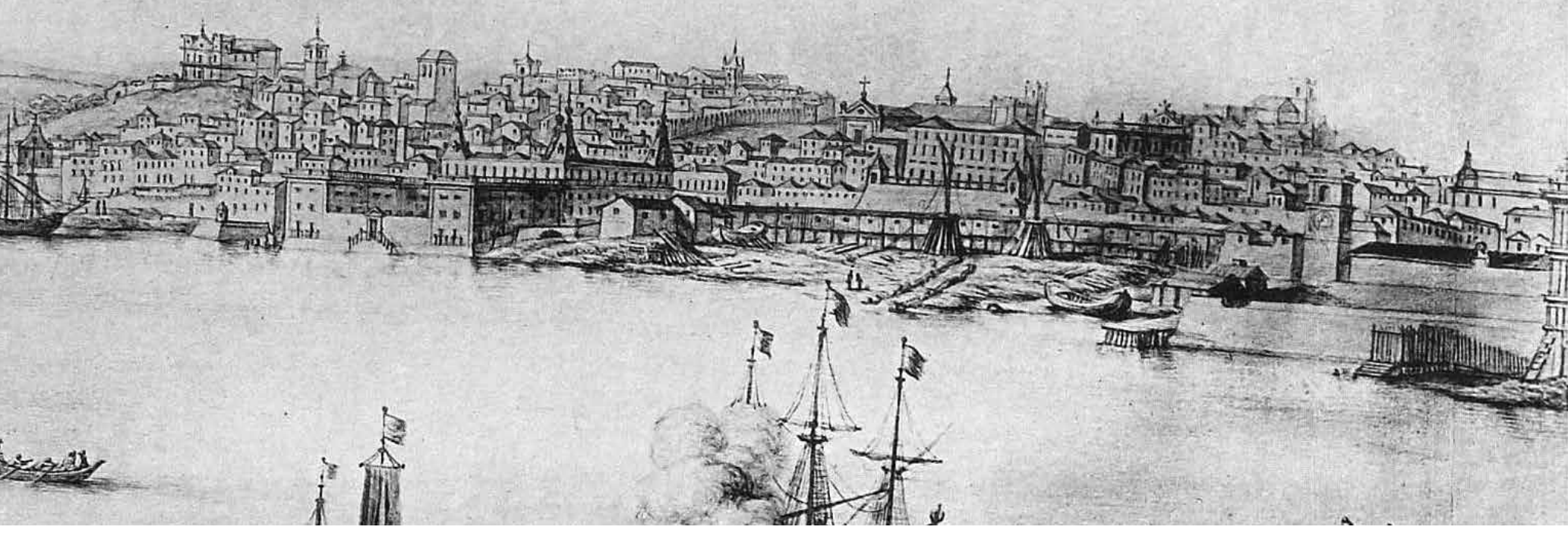

Pier Maria Baldi. Detalle de la vista de Lisboa para Viaje de Cosme de Médicis por España y Portugal (1668-1669) / edicion y notas por Angel Sánchez Rivero y Angela Mariutti de Sánchez Rivero (1933).

de Arruda. Esta torre fue modificada por Filippo Terzi. Terzi se hallaba en Portugal en el último tercio del siglo XVI invitado por el rey Sebastián I. Con la anexión de Portugal por Felipe II, recibió el encargo de modificar el Paço da Ribeira para el que construyó el famoso torreón que sustituía a la torre-mirador y que aparece constantemente en la iconografía de los siglos XVII y XVIII, hasta su desaparición a causa del terremoto de 1755. En Lisboa podemos ver algunas de sus obras como la nueva Iglesia de San Vicente de Fora con la colaboración de Juan de Herrera.

La construcción del palacio implicó,

[1] un desplazamiento de las atarazanas hacia occidente, a la zona de Cataque-Farás ${ }^{19}$, zona que creció como un nuevo arrabal fuera de las murallas fernandinas.

[2] el terraplenado de la zona frente al palacio, ampliando su superficie y adelantando la línea de costa, que,

[3] con la construcción, en distintos momentos, de la Aduana Nova ${ }^{20}$, del Granero Real y del templo de la Misericordia.

19 Como curiosidad, el topónimo Cata-que-Farás se convierte en el gentilicio Cataquefarás-marinero que viaja con los protagonistas- en la novela Tirant lo Blanc de Tirant lo blanc de Joanot Martorell, escrita entre 1460 y 1464, publicada primero en Valencia (1497) y posteriormente en Barcelona (1490). Siglos después, el compositor Roland Besson, compuso en 1998, una sardana con este nombre.

20 La aduana compartía espacio con la Casa da Suplicação, también conocida como Tribunal da Corte. La Casa da Suplicação era un tribunal superior del reino, al igual que la Casa do Cível. Probablemente fue creado a mediados del siglo XV y se extinguió en 1833, dando lugar a un Tribunal de Apelaciones. Estaba presidido por un presidente y organizado en dos secciones. Además de perseguir determinados delitos, cada sección tenía competencias específicas. Correspondía a la primera conocer de las peticiones y decidir sobre los indultos y las conmutaciones de penas. La segunda trataba de los recursos para los que la Casa Civil no tenía competencia. 


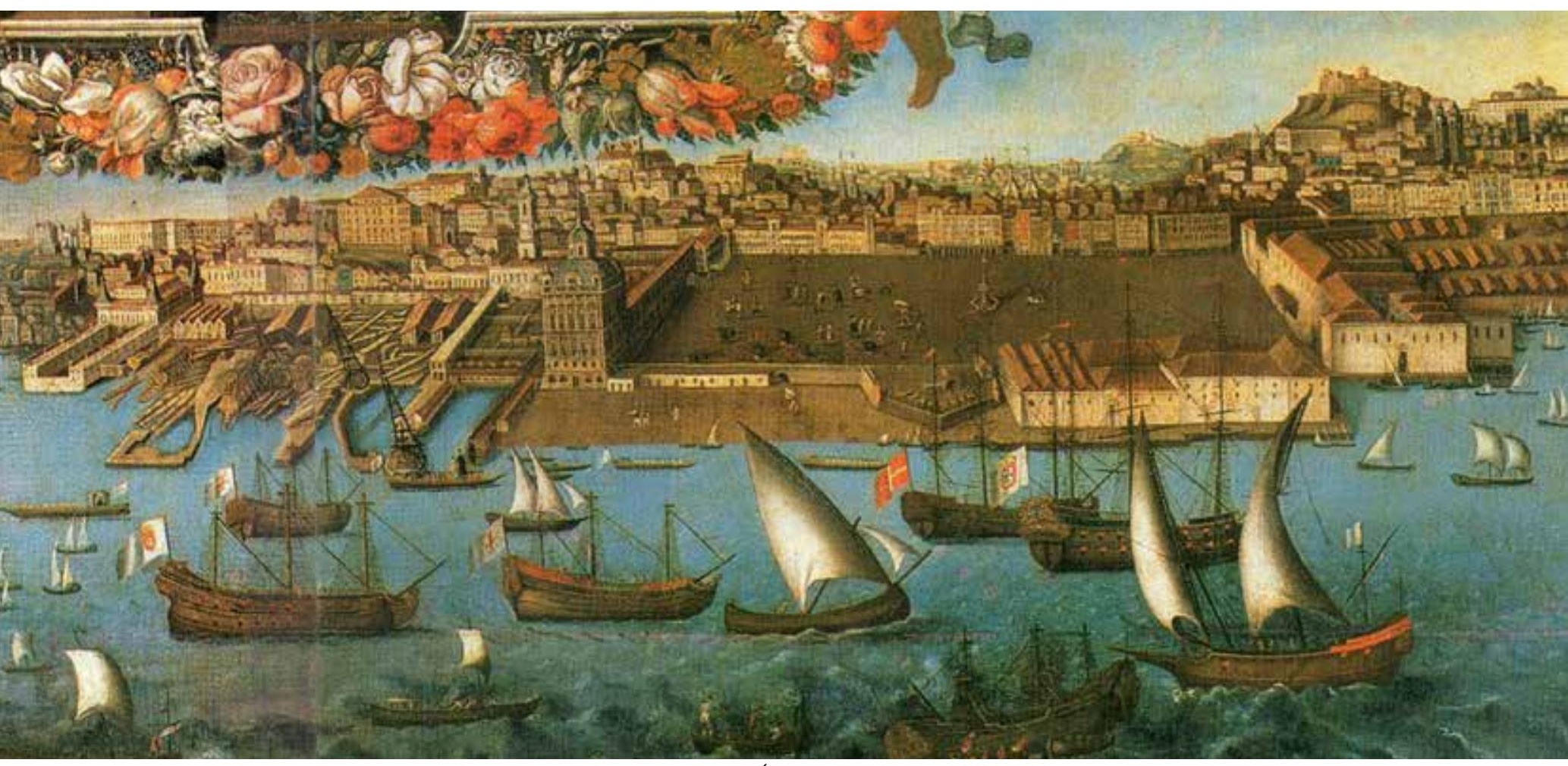

Fragmento. "D. João III e o núncio apostólico da Índia, ou A partida de São Francisco Xavier em 1541" de José Pinhão de Matos, c. 1730 Fuente: MNAA. Lisboa

"La nueva aduana, se extiende hasta la orla del mar. Es una mole inmensa de piedra, sustentada por grandes postes, muy juntos, clavados a mazazos en el mar, construida a expensas y por orden del mismo rey" (Góis 1554: 58)

El Granero Real, el Terreiro do Trigo, fue edificado a inicios del reinado de Juan III (Carita 1990:100) y del que Góis decía:

"El cuarto monumento, digno de eterna memoria del rey Don João III, destaca, junto al vestíbulo, en el ala este [del Terreiro do Paço]: una doble construcción de magníficos edificios, con otras tantas galerías, treinta y dos arcos a ambos lados, ochenta almacenes, teniendo en el centro un patio, liso y no muy ancho. Con justicia se le puede llamar el granero de la nación y nodriza de Portugal" (Góis 1554:57-58)

La Iglesia de la Misericordia (1502)

"Construida en piedra, construida con elegancia. Se mantiene, no por el alto alquiler de los edificios, ni por sumas anuales, como la mayoría de las instituciones de nuestros días, sino solo por la caridad de hombres nobles y gente piadosa, tanto que apenas se puede creer la cantidad de dinero que se gasta anualmente en los pobres, recaudado por aportación privada y espontánea". (Góis 1554:51-52)

La disposición de estos edificios, genera una forma en $U$ de este espacio, forma que configurará una pre-existencia, cuando, tras el terremoto de 1755 , se proceda a la creación de la 'ciudad nueva' presidida por la gran plaza del Comercio. Como señala Caetano (Caetano 2004), los edificios, especialmente la Aduana y el Granero, estructurarán este gran espacio en diversos espacios funcionales para la actividad portuaria, implicando la construcción de diversos muelles-Cais do Carváo, Cais da Madeira en la parte oriental, Cais da Pedra, Cais da Casa da Índia en la occidental-, y 

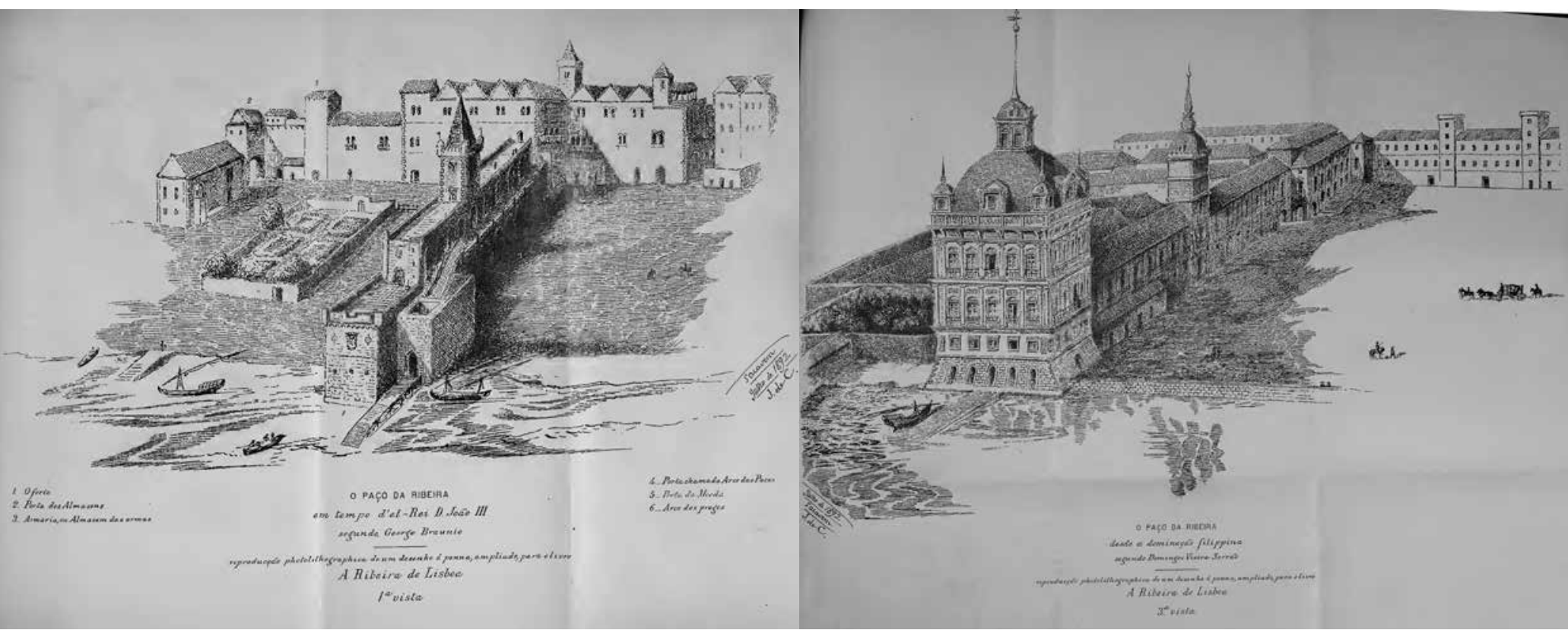

Del Paço da Ribeira de Manuel I lizda) al Paço desde la dominación filipina (dcha). Dibujos de Julho de Castilho en 1892

mercados con una variada e intensa ocupación y uso ciudadano

"En esta vasta plaza, está el mercado de pescados y dulces, donde pescaderos, hortelanos, pasteleros, carniceros, panaderos, vienen todos los días a vender lo que traen para alimentar la ciudad; se ven tiendas que venden comida, vino, vendedores ambulantes, posaderos, tejedores. En la lonja hay un gran número de cestas, colocadas alli por orden de la autoridad, con las que, en cuanto atracan las barcas de los pescadores, el pescado es transportado por esclavos a los vendedores de la plaza". (Góis 1558)

La Ribera se caracteriza por ser un gran espacio público multifuncional. Su límite con el agua es puerto. La zona entre el agua y la franja edificada, grandes plazas multifuncionales. La Ribera se articula con el resto de la ciudad mediante las puertas de las murallas $y$, por medio de un nuevo conector (Rua Nova d'El-Rei) que la relaciona con otras áreas centrales como es el Rossio. La Ribera funciona como gran "puerta de entrada", en este caso no sólo a la ciudad sino, también, al Reino. Por ello paulatinamente se operan actuaciones de decoro urbano, mediante la arquitectura de los edificios o mediante la introducción de fuentes artísticas.

"En la ribera nacen numerosas fuentes, con cañerías subterráneas a diferentes puntos de la ciudad, de donde los habitantes acuden a buscar agua. Una de ellas, la Fonte do Rei, tiene una construcción admirable, con columnas y arcos de mármol. Echa tal abundancia de agua, a través de seis grifos, que sólo ella alcanzaría para dar de beber agua al mundo entero. Esta misma fuente, por la cantidad, pureza, sabor y ligereza del agua, iguala o supera a todas las fuentes que recuerdo haber visto. A veces emana agua caliente; luego reposa un rato, y luego sale agua muy fresca, muy pura, que es un placer beber.

"Cerca, nacen dos manantiales más. En uno, [se refiere al chafariz da Praia de 1517] el agua brota a borbotones y luego fluye, como una acequia, hacia el mar. Si estuviera a mayor distancia, muchos molinos o aceñas podrían, a lo largo del año, ser movidos por la fuerza de esta corriente. Como mínimo, es de gran utilidad para lavanderas, curtidores y bataneros. El otro está cerca, 


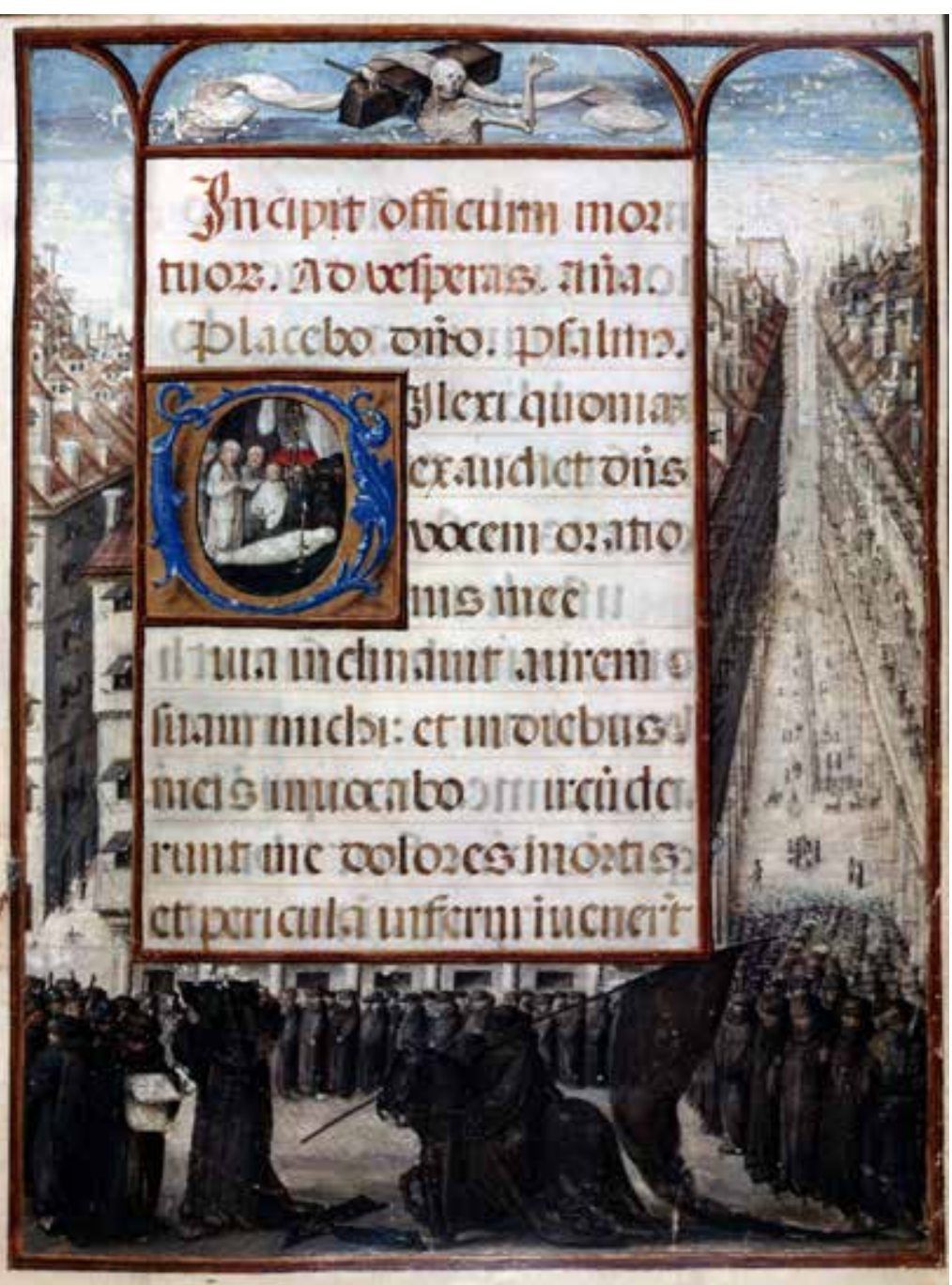

Libro de Horas llamado de D. Manuel (Ofício de los Muertos), atribuído a António de Holanda, 1517- 1551. Lisboa, Fuente: Museu Nacional de Arte Antiga N. de Inv. 14/129v. e 130.Como señala Trindade (2016) "Con una perspectiva audaz, el iluminador acentúa la monumentalidad de esta parte de la ciudad, hasta hace muy poco tiempo identificada consensualmente como la Rua Nova dos Mercadores. La calle paralela a ésta, en cambio, fue sistemáticamente relegada al anonimato, no apareciendo relevante en la composición general [Sin embargo aparece analizada por Carita como ejemplo de edificio con pisos en consola(Carita 1999p4)]. Contrariamente a la opinión general que identifica-casi sin cuestionamientos-esta representación con la Rua Nova dos Mercadores, Pedro Cid [CID, Pedro de Aboim Inglez - "O Livro de Horas dito de D. Manuel. Algumas precisões". História, Ano XXII, n. 26, (Jun. 2000), pp. 46-55], en un breve pero incisivo artículo escrito en el año 2000, adelantaba la hipótesis de que se trataba, al fin y al cabo, de otra Rua Nova que, perpendicular a la anterior, establecía la conexión directa entre Rossio y Ribeira: Rua Nova d'El Rei".
Alemania", dedicándose la mayor parte de ellos al tráfico de mercaderías. Viven allí, también, riquísimos judíos, casi todos mercaderes, "pero que sólo viven del trabajo de sus esclavos" (Münzer 1924).

La rua Nova dos Mercadores conectaba com el Rossio a través de la Rua Nova d'El-Rei -mandada alinear por Manuel I sobre el trazado de antiguas callejuelas medievales. La Rua Nova d'El-Rei tiene su origen en 1466, cuando Afonso $\mathrm{V}$ manda encauzar y cubrir una riera que discurría por la zona, creando la nueva arteria también por este motivo designada como "calle nueva del caño". La mitad norte de la calle, la más próxima al Rossio,sin embargo, sería aún más reciente: aunque ya se menciona en el auto de aclamación de D. João II, de 1481, sobre el camino emprendido hasta Rossio, lo cierto es que, en pleno reinado manuelino, se estaba procediendo a su apertura. En 1501 se permutan propiedades donde el rey manda abrir la calle, según los principios y reglas expuestos en los Regimentos da Riberira (Carita 1999). No es de extrañar, por tanto, que en ésta, a diferencia de la antigua Rua Nova dos Mercadores, los principios urbanísticos manuelinos se pudieran poner fácilmente en práctica: estructura amplia y rectilínea, con fachadas claramente disciplinadas, uniformes en altura y perfil. Una nueva calle en la que abundan "los grabadores, joyeros, orfebres, doradores, y las casas de cambio" (Góis 1558:56), unos artesanos que ocuparán esta calle por designación real de Manuel I al reordenar las calles de 
la Baixa para los distintos oficios. Posteriormente, esta calle pasó a llamarse Rua dos Ourives de Ouro (orfebres del oro) que se abría en un Largo dos Douradores antes de llegar al Rossio, separándolos de los Ourives da Prata que ocuparían la calle de este nombre, perpendicular a la Rua Nova dos Mercadores, pero en su otro extremo. Las actuales Rua Áurea y Rua da Prata están trazadas en buena parte de su recorrido sobre las preexistentes.

\section{Bairro Alto: trazado ortogonal, quarteirões ${ }^{23}$ y construcción}

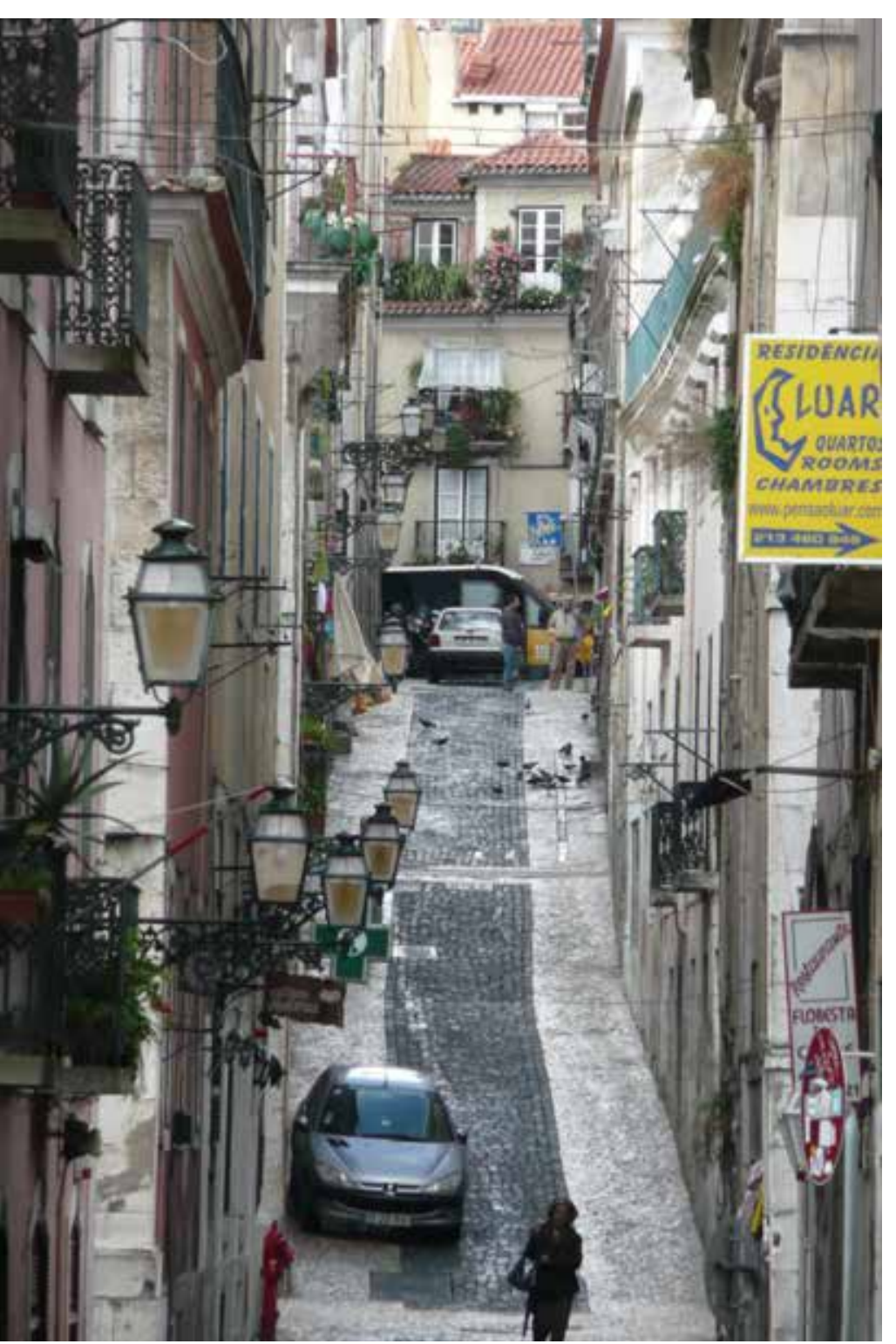

La reordenación manuelina de Lisboa, se proyectó más allá de los muros de la ciudad. La Vila Nova do Andrade (actual Barrio Alto), emergería en las afueras de la ciudad entre el río-zona de Cata-queFarás- y la ermita de San Roque donde, desde principios del siglo XVI existía un cementerio para enterrar a las víctimas de la peste. En 1506 el rey Manuel I pidió a Venecia una reliquia de este santo con el fin de proteger a la población de Lisboa. Para la veneración de la reliquia, los habitantes de la ciudad construyeron una ermita junto al cementerio.

En la zona sur, en 1498, se realiza la primera operación de parcelación, mediante el procedimiento de enfiteusis que como vimos fue el mismo utilizado en el barrio de Ribera de Barcelona (Remesar 2021, p56). A la que seguirá

23 Cuadrángulo formado por la reunión de casas o edificios que dan a cuatro calles o callejones. En el caso del Bairro Alto generalmente rectángulos. Esta organización es similar a la que vimos en la primera parte de este trabajo para el barrio de la Ribera de Barcelona o el Quatieri dei Spagnoli en Nápoles. El cuadrángulo se divide en varias parcelas que darán lugar al sistema de construcción entre medianeras tan característico de las poblaciones del sur de Europa. "O módulo gerador do traçado urbano passa a definir-se através do quarteirão de base rectangular como vemos surgir logo nos primeiros anos do século XVI nos quarteirões de Cata-Que-Farás, da Vila Nova da Oliveira e da Vila Nova de Andrade, evoluindo esta última para o Bairro Alto, que virá a constituir, em termos patrimoniais, a estrutura urbana mais significativa desta época. No caso do Bairro Alto, observamos a tendência para uma proporção de lote em duplo quadrado com 30 por 60 palmos". (Carita 1999:90). 


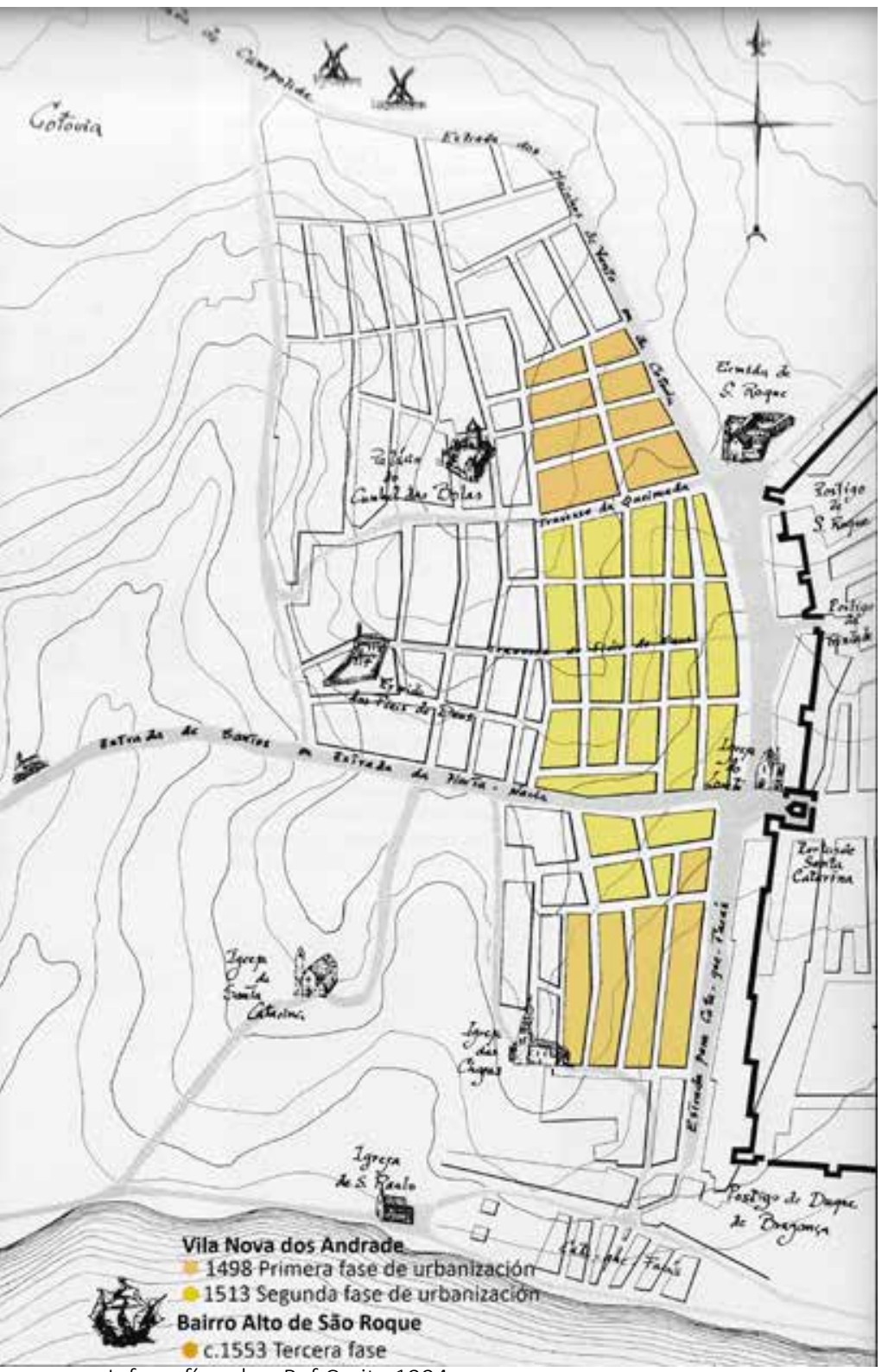

Infografía sobre Ref Carita 1994 una segunda en 1513. Lopo de Atouguia acordó con los arrendatarios Bartolomeu de Andrade y su mujer, la subtenencia de las fincas en solares destinados a la construcción de viviendas; la nueva urbanización se designó entonces como Vila Nova de Andrade.

Los lotes de edificación se articulan en una red ortogonal, con base rectangular, partiendo inicialmente del esquema "calle-travesío", para poco después pasar a una ordenación por quarteirões - manzanas. Las calles corren perpendicularmente al río, las travesías en paralelo, con la zona central del nuevo barrio atravesada por el camino a Santos que entraba en la ciudad por las puertas de Santa Catarina. En 1523 ya se habían construido 408 edificios con una población de 1.600 habitantes, llegando a los 8.679 en 1551, datos que nos indican el rápido creciente de la zona, tanto en edificios como en población.

El barrio, en sus diversas fases, se construye siguiendo las normas manuelinas (Carita 1999): Las manzanas presentaran unos solares cuadrangulares que sustituyen los antiguos solares medievales, estrechos y alargados. La construcción presenta unos edificios de dos plantas en mampostería de piedra y cal, con jambas rectas de piedra de calcárea (pedra de lioz), lo que introduce una 'arquitectura de programa' basada en una estética unitaria, que, además, cumplirá con otras reglas que regulan los balcones con un máximo de anchura de máximo un palmo y medio así como los voladizos. Los nuevos edificios deben tener fachadas planas y alineadas - lo que supone trazar a cordel el límite de las fachadas- que además debían construirse a plomada. (Leal 2005)

La tercera fase de urbanización se plateará a partir de la llegada de los jesuitas. Los jesuitas Ilegan a Lisboa en 1540, y tras instalarse, inicialmente, en la zona da Mouraria. El rey João III'24, les asignó el Convento de Santo Antão, en Mouraria, donde, en 1552,

24 El contencioso con la Compañía de Jesús y que llevará a su expulsión de Portugal, se inicia en el reinado de Juan III, con una crítica de parte de la nobleza sobre su gran influencia en la Corte. Estas críticas 
se fundó el primer colegio jesuita del mundo. El éxito de estos primeros estudios públicos demostró la insuficiencia del edificio de Santo Antão y lanzó a la Compañía de Jesús a una gran empresa que, con la protección del Cardenal D. Henrique (151280), se convirtió en el Colegio de Santo Antão-o-Novo. Su construcción se inicia en 1579, con un proyecto grandioso del Baltazar Álvares e es inaugurado en noviembre de 1593, El colegio- hoy clasificado como bien de interés público por la Ley 8/83, de 24 de enero-estaba situado en el Campo de Sant'Ana. Sería completado con una grandiosa iglesia, comenzada en 1613 y terminada el 31 de julio. de 1652. Tras la expulsión de los jesuitas el colegio pasa a albergar el Hospital de São José con los pacientes del Hospital de Todos-os-Santos en el Rossio, destruido por el terremoto de 1755,

En 1553 los jesuitas llegan al alto de San Roque, donde, sobre la anterior ermita, se construye la primera iglesia jesuítica, y la casa profesa anexa de Portugal. Fue diseñada por el arquitecto militar Afonso Álvares ${ }^{25}$ en 1566, dirigiendo las obras hasta 1577, y concebida originalmente como una iglesia de tres naves, aunque finalmente- parece que en base a "ciertos dibujos" llegados de Roma en 1564- se construirá de una única nave. Este argumento, poco contrastado, aparece por el hecho de que los trabajos en la iglesia de Lisboa, son coetáneos con los desarrollados para la iglesia del Gesú de Roma ${ }^{26}$.

La presencia de los jesuitas provocará una tercera fase de urbanización, el barrio Alto de São Roque - que a la postre daría el nombre al conjunto- al constituir un polo de atracción para la nobleza lisboeta que comenzó a construir allí sus palacios con el objetivo de acercarse a los sacerdotes de la Compañía que gozaban de un amplio reconocimiento cultural y social en la época. El Barrio Alto de San Roque se desarrollará entre la iglesia de San Roque y el camino de Campolide hasta la zona del Convento de San Pedro de Alcántara que no se edificará hasta 1681. El trazado de esta nueva urbanización sigue siendo ortogonal articulado según el sistema parcelario de la 'manzana'.

aumentarán en el siglo XVIII por causa de las estancias jesuíticas en la región del Paraná., que llevará a su expulsión de Portugal en 1759, aunque la excusa fue la posible participación de los jesuitas en un atentado al rey José I en 1758. Las misiones guaraníes constituyeron un importantísimo freno a las aspiraciones expansionistas portuguesas, cuyas bandas de bandeirantes se dedicaban a la caza de indios para venderlos como esclavos - un relato edulcorado de esta situación se puede ver en la película The Mission (1986) de Rolan Joffé. Algún tiempo después los jesuitas fueron expulsados de Francia (1762) y de España (1773) Ilegando el Papa Clemene XIV a suprimir esta orden que sería restituida por Pio VII en 1814.

25 Afonso Álvares fue maestro de obras del rey portugués Sebastián de Portugal y diseñó, además, el Monasterio de São Bento en Lisboa en 1571, que se perdió en el terremoto de Lisboa de 1755, y es ahora parcialmente el sitio del Parlamento portugués.

26 Los primeros proyectos de la iglesia, tal y como exigía Ignacio de Loyola, habían sido diseñados por Nanni di Baccio Bigi, un arquitecto florentino. En 1554 Michelangelo rediseña el proyecto que, después, sería finalizado por Vignola (1568), con dos requisitos:[1] Un gran pasillo con un púlpito lateral, para facilitar la predicación y [2] un altar central para la celebración de la Eucaristía. La obra fue dirigida por Vignola 1568 a 1575. Después de la muerte de Vignola, la obra pasa bajo la dirección de Giacomo della Porta hasta 1580. El della Porta reelabora el diseño de la fachada y proyectó la cúpula. Se consagró en 1584. (Álvaro Zamora et al 2012; Varela \& Lobo 2012) 


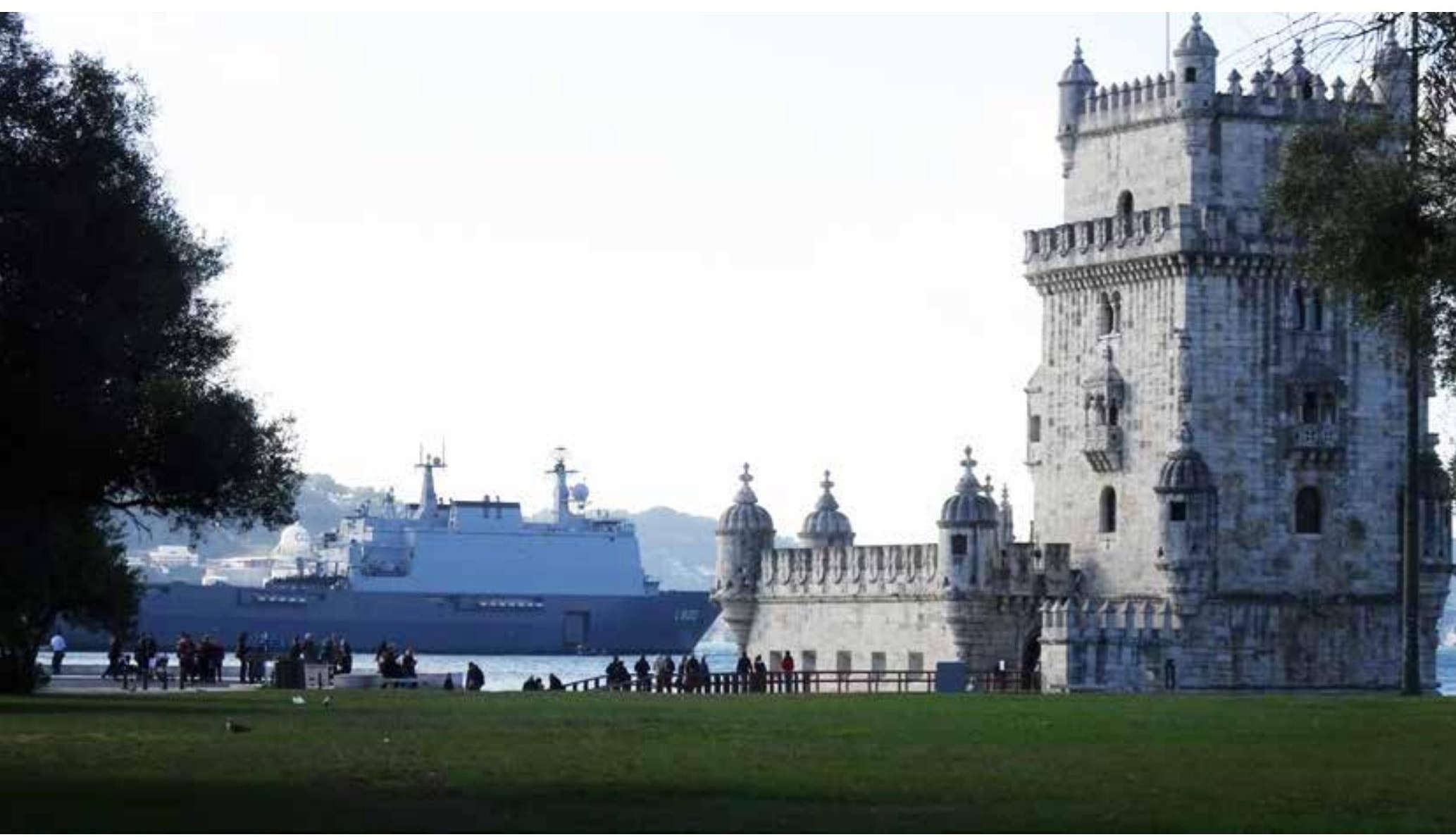

Torre de Belén o de San Vicente. Uno de los ejemplos de "estilo manuelino" en Lisboa. Concebida como fortaleza para controlar el estuario del Tajo, fue construida entre 1516 y 1519, Es una obra de Francisco de Arruda

Como bien indican Carita (Carita 1999) y França (França 2008) las operaciones desarrolladas durante el reinado de Manuel I, deben entenderse como prácticas generalizadas para el conjunto de la ciudad y no como simples operaciones puntales como las desarrolladas en siglos anteriores, y se fundamentan en una serie de reglamentos llegándose, incluso, a una modificación de Carta de la Ciudad medieval y a la institución de nuevos cargos para las obras del imperio.

Desde una valoración apresurada, podríamos pensar que la urbanización del barrio Alto refleja la incorporación al urbanismo portugués de los principios renacentistas. Es fácil de pensar, puesto que diplomáticos, comerciantes, estudiantes, humanistas, eruditos y artistas de toda Europa fueron atraídos a Portugal durante la época de los Descubrimientos. Del mismo modo diplomáticos, comerciantes, humanistas, eruditos y artistas portugueses, viajaron por Europa y especialmente por Italia estando en contacto con los centros del renacimiento italiano. Lo vimos más arriba en el caso de la Casa de los Bicos de Brás de Albuquerque.

Sin embargo, el Renacimiento portugués, en su mayor parte, no siguió los caminos del Renacimiento italiano en cuanto a arquitectura, aunque sí lo hizo en relación a otras artes como la escultura. Durante la mayor parte del Renacimiento portugués, su arquitectura fue en gran parte la continuación y elaboración del estilo gótico en lo que ha venido en llamarse "estilo manuelino". Como señalara Domènech i Montaner, 
populares que se caracterizan, como señala Carita (1999; 2015) un "manuelino utilitario" que puede manejarse con las herramientas conceptuales derivadas de la Baja Edad Media y que definirá la forma arquitectónica en Portugal durante casi dos siglos. Deberíamos recordar que el clasicismo del Cinquecento fue desde el principio, más un ideal y una ficción que una realidad (Hauser 1951), en parte porque el Renacimiento fue una época esencialmente dinámica e innovadora (Panofsky 1960)

Planta da cidade de Lisboa, na margem do rio Tejo: desde o Bairro Alto até Santo Amaro. [Segunda mitad del siglo XVI según datos de la Biblioteca Nacional de Brasil]. Disponible en: http://objdigital.bn.br/acervo_digital/div_cartografia/cart1044544/cart1044544. jpg.

\section{El litoral se convierte en Ribeira ${ }^{27}$ Creciendo hacia el occidente y oriente}

Damião de Góis inicia su descripción de la ciudad de Lisboa en la actual zona de Belém, donde destaca el Monasterio de los Jerónimos, obra cumbre del llamado 'estilo manuelino'

"Hay un templo grandioso, de increible suntuosidad y magnificencia, consagrado a Santa María, con un monasterio de los religiosos que profesan la regla de San Jerónimo. En el interior, el rey Don Manuel se construyó un mausoleo. Su hijo, el rey Don João III, que ahora reina felizmente, ordenó una ampliación del monumento, que aún está en construcción" (Gois 1558).

Cerca del monasterio, refiere la Torre de Belém

"Se levanta una torre de cuatro pisos, hecha de sillería, que don Manuel hizo construir sobre rocas, arrojadas al mar, para que, rodeada de agua por todos lados, estuviese más segura contra cualquier violencia y ataque repentino de los enemigos; las naves no podían acercarse a la capital si los que estaban de guardia en la torre no lo consentían". (Gois 1558).

Describe su trayecto hasta la ciudad señalando que por todo el trayecto se pueden ver muchas fincas suburbanas "de admirable elegancia y agradables" rodeadas de campos y pastos, además de una gran cantidad de frutales de todo tipo. Campos por todas partes, puntuados por casas de campo, aldeas, iglesias y conventos "tan hermosos y en tan gran número que las fincas y casas de campo de los alrededores suman más de seiscientas" (Gois 1558). Góis no habla del oriente de la ciudad, más 27 En este punto debemos establecer una precisión léxica. A lo largo de este trabajo hemos hablado de 'Ribeira' que en portugués significa zona tanto la margen de un río, como la zona donde se varan y mantienen los navíos o donde hay una zona de mercado de pescado. 'Marinha' se refiere al conjunto del litoral. 
António de Holanda y Simón Berning.

Vista de Lisboa in Genealogia do Infante Dom Fernando de Portugal. (1530-1535).

Pagina general y detalle, Se aprecia la Rocha do Conde de Óbidos y su Palacio, Alcântara, el Monasterio de Belém y la Torre de Belém, así como una vista general de Lisboa (C) British Library

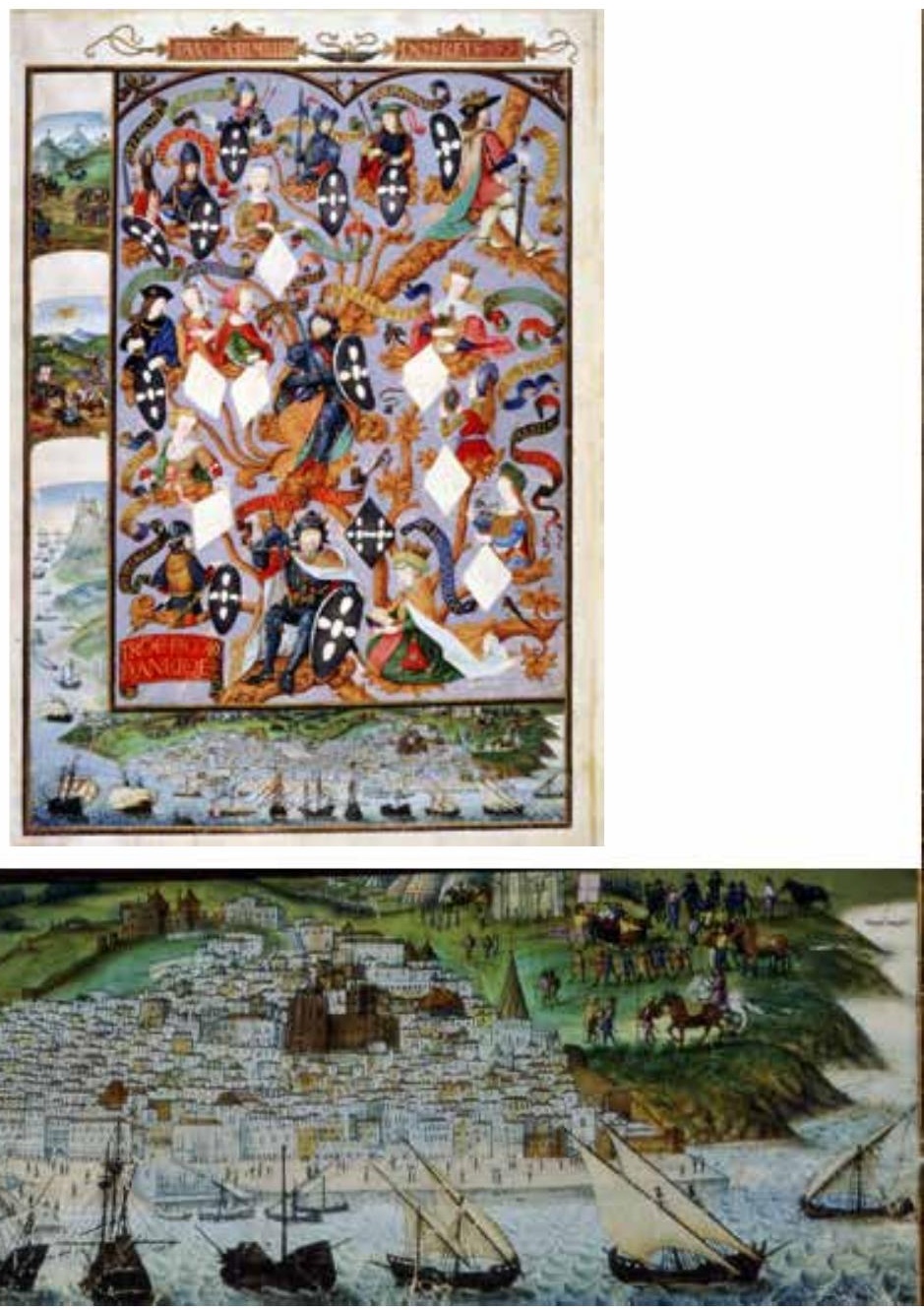

allá das Portas da Cruz en el límite de Alfama. Sin embargo, la estructura portuaria de la ciudad crecía, también, hacia oriente donde se instalan los Cais do Carvão (Carbón) y el Cais da Madeira, así como la Casa da Póvora, la fundición de cañones y los hornos de cal. Además, en esta zona se construirán diversos conventos, como el de Madre Deus (1509) que actualmente aloja el Museo Nacional del Azulejo, o el Convento de São Francisco de Xabregas (1460).

Francisco de Holanda indicaba a Sebastián I que había comprobado que el rey no tenía casa fija en Lisboa, digna de un rey que "vive a veces en la Ribeira, a veces en Estaos, a veces en Santos Velho, que no son lugares de Reyes, sin tener un lugar donde reclinar la cabeza en esta gran ciudad, que tendría que ser como su casa". (Holanda 1571) . Por ello recomienda al rey que siga los pasos de su abuelo, el rey Juan III, cuando queriendo fijar su residencia en Lisboa, escogió el sitio de Xabregas, donde empezó la construcción de un palacio, entre el convento de Madre Déus (1509) y el convento de São Francisco (1456-1460), un palacio que iba a ser de

"los mejores de Portugal (aunque con algunas imperfecciones, o descuidos en el diseño) que, a su muerte, no estaban terminados [. . . Y Y si le parece bien [. . .] termine V. A. los palacios de Enxobregas [.. . Y Y si falta el día y la caza (mientras estáis obligados a tener en cuenta Lisboa y su corte), cercar media legua de 


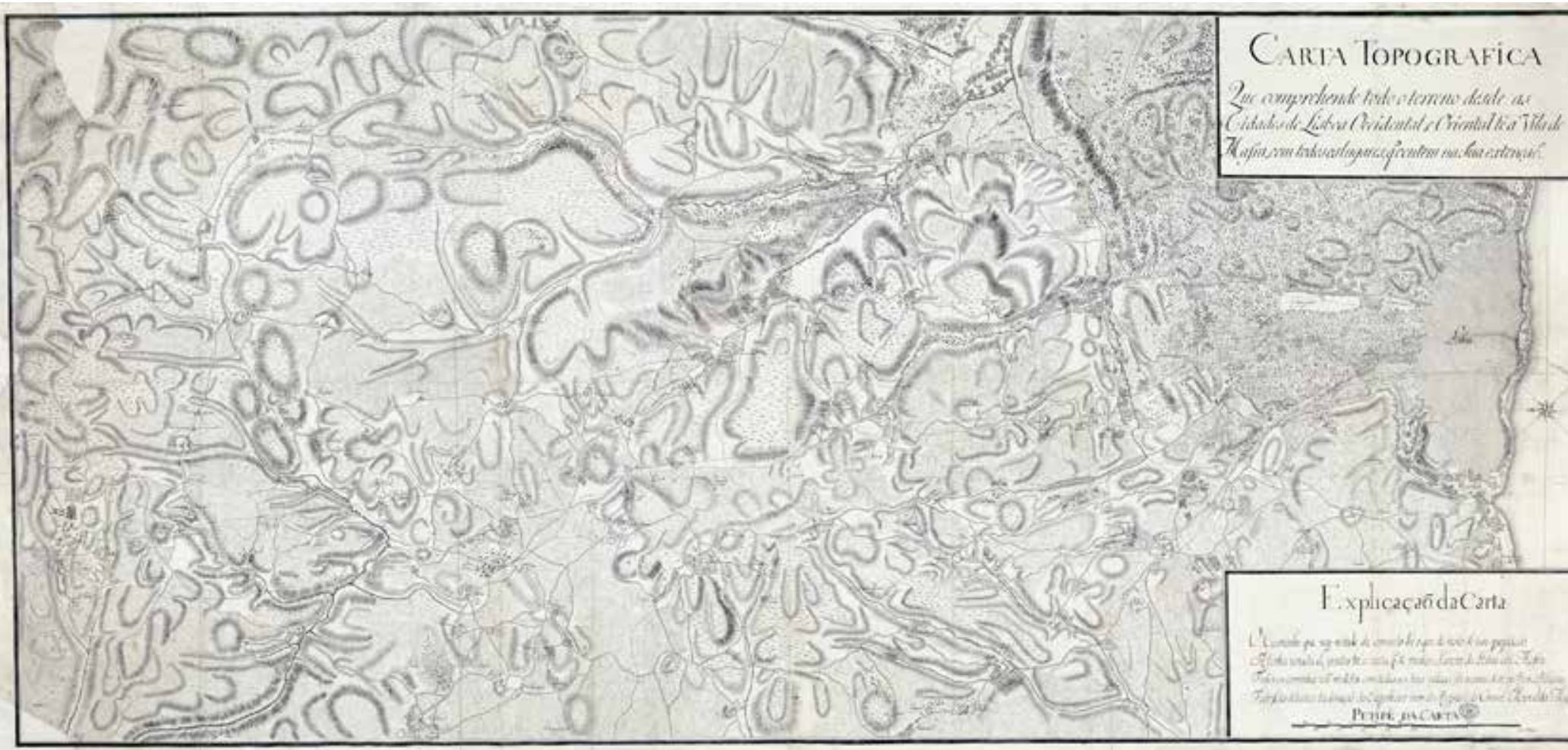

Carta topografica que comprehende todo o terreno desde as cidades de Lisboa Occidental e Oriental té a vila da Mafra, com todos os lugares, q. contem na sua extenção. Material cartográfico] / tudo feito debaixo da direcção do Engenheiro mor. do Reyno, e do Coronel Manoel da Maya La intervención de Manuel da Maía como coronel de infantería con ejercicio de ingeniero permite situar la carta entre 1718, cuando fue promovido a este grado por sus servicios prestados, especialmente por el levantamiento de la planta de Lisboa oriental y occidental (1718) hoy perdida; y 1738, cuando lo fue como brigadier de infantería con el mismo ejercicio de ingeniero. Fuente: Cartografía de Lisboa. Séculos XVII a XX, Comissão Nacional para as Comemorações dos Descobrimentos Portugueses, Exposição, Museu da Cidade, 9 de julho a 9 de agosto de 1997, no âmbito do XVII Congreso Internacional de História da Cartografia, p. 42, no 11. https://bvpb.mcu.es/gl/consulta/registro.do?id=423233

tierra desde allí hasta Chelas y hasta más allá de S. Bento, y haced un parque con muchos puercos y ciervos y pájaros, y bosques y arboledas, y fuentes y casas de recreo mucho mejores que las que hizo en Fontainebleau El-Rei de França". (Holanda 1571)

La cita de Holanda indica que desde la época de João III - al inicio del paulatino declive de la monarquía lusa que concluyó con los 60 años de gobierno de la dinastía Habsburgo (1580-1640)- los reyes buscan una residencia alejada del centro políticocomercial-portuario de la ciudad, a pesar de la persistencia simbólica de los Paços do Terreiro que será reforzada en la etapa filipina por las mejoras del palacio de la mano de Terzi. En la zona cercana al Calvario, pasado el puente de Alcántara hacia el oeste, Felipe II de Portugal mandaría edificar, en 1603, un palacio a Teodoro Frías que fue su residencia en las etapas que estuvo en Portugal y, a partir de 1640, de los reyes D. João IV, D. Afonso VI e Pedro II. Este palacio desaparecería en el terremoto de 1755. E incluso, como acontecerá en el reinado de João $\mathrm{V}$, se vislumbra un cierto intento de crear un nuevo centro, como sucederá con el encargo a Filippo Juvarra en 1719. El Proyecto del Palacio Real y Catedral Patriarcal de Lisboa fue una ambiciosa propuesta de un conjunto monumental situado frene al río Tajo, pensado para albergar tanto el palacio real del rey Juan $\vee$ de Portugal como una nueva residencia e iglesia para el Patriarca de Lisboa. Su lugar de construcción sería en Ribera al oeste del Terreiro do Paço-zona de la actual Lapa-. Parece que la elección del emplazamiento y el plazo de 30 años 

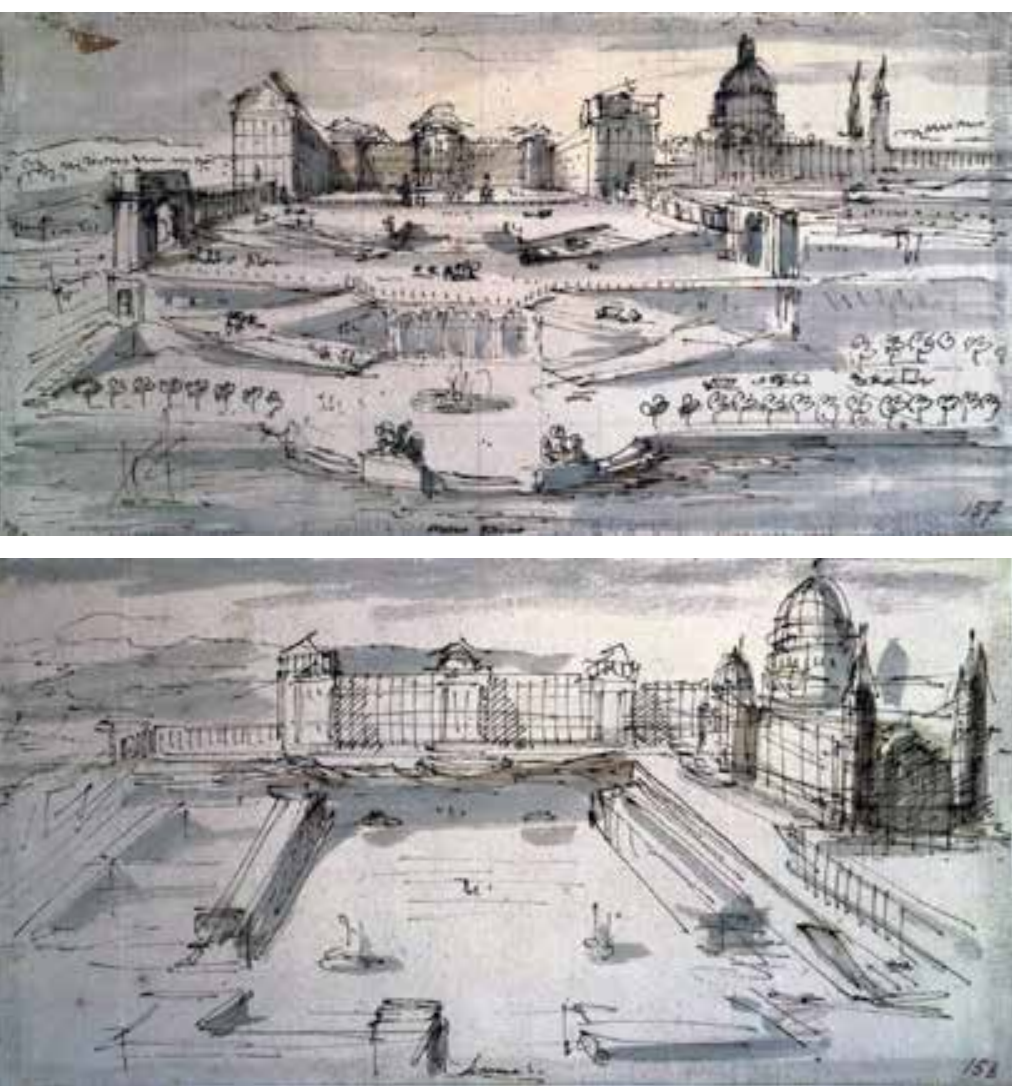

Dos estudios de F. Juvarra (c.1719) para el proyecto del nuevo palacio real y la nueva sede del Patriarcado de Lisboa. Ref. Torino, Museo Cívico.

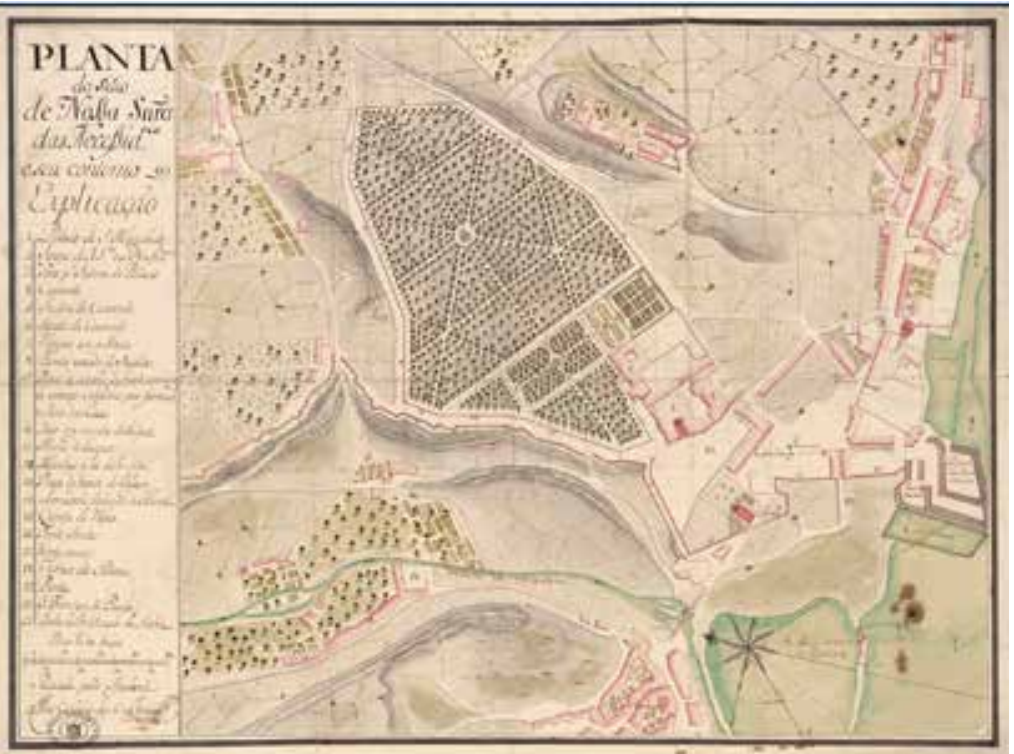

Planta do sitio de Nossa S[e]n[o]ra das Necessid[ad]es e seu contorno [Material cartográfico] / Riscada pello Ajudante Jozé Custodio de Sá e Faria. Se puede fechar entre 1745-1749. Ref: Biblioteca Digital Real Academia de la Historia, https://bibliotecadigital.rah.es/es/consulta/registro. do?id=12563 de construcción que dio Juvarra (França 1997), implicó desestimar el proyecto. Pero, se mantuvo la idea de crear un nuevo sitio del poder real - separado tanto de los símbolos arquitectónicos de la época filipina, del ámbito portuario-comercial y de la ciudad medieval-, propulsado por el flujo del oro y diamantes que desde 1690 llegaba desde Brasil. En paralelo a la operación Juvarra, João $\mathrm{V}$, orienta su interés a construir este nuevo centro en Mafra, aunque, sin embargo, no abandona la idea de 'cambiar de residencia' en Lisboa. Así, en 1726 adquiere la llamada Quinta de Baixo o Quinta da Praia, y la habilita como "Casa Real de Campo de Belém", hoy palacio de la Presidencia de la República; realizará modificaciones en los antiguos Paços da Ribeira y, a partir de 1742, mandará edificar el Palácio das Necessidades.

En todo caso, del itinerario descrito por Góis comprobamos que no existía un recorrido litoral que uniera la ciudad con la zona de Belém por la costa. El valle del río Alcântara, con su delta formando una gran laguna donde, desde la edad media, operaba un molino de marea (Oliveira 2017), junto al promontorio llamado "rocha do conde de Óbidos" suponían una barrera física insalvable para establecer una continuidad funcional entre Lisboa y Belém. La ciudad crece paulatinamente hacia occidente con la instalación de grandes palacios o la aparición de nuevos barrios como el barrio da Madragõa, que con anterioridad al terremoto de 1755 se llamaba Moçambo, barrio habitado por población africana. 
construcción del Bairro Alto (Carita,1994). Como señala Correia (1991) sus volumetrías son paralelepípedos rectangulares compactos, la línea recta se utiliza para definir casi todo y se evita la decoración siempre que sea posible, lo que produce edificios bajos y limpios. Una actitud arquitectónica típicamente portuguesa, nacida del intento de preservar la identidad nacional, en un período de crisis política, económica y social. Esta actitud "chã" Ilegará a condicionar los ejemplos de arquitectura manierista e incluso, afectará a los modos de hacer durante la reconstrucción de la Lisboa Pombalina e, como como señala Leal (2013), mucho más allá en el tiempo. Para Kubler, el río de riqueza que generarán el oro y diamantes de Brasil, marcará el inicio de una nueva época vinculada con el movimiento Barroco internacional y el modelo de régimen absolutista.

Cuando Manuel de Maia, tras el terremoto de 1755, presenta al rey su "Dissertação" sobre la reconstrucción de Lisboa, establece una correlación entre 'Cómo' y 'Dónde' debe realizarse. El cómo implicará, en tres de sus propuestas iniciales, una serie de medidas basadas en reducir la densidad residencial de la ciudad, recortando el número de pisos de las casas y ensanchando las calles. Medidas útiles para prevenir el impacto de nuevos terremotos -especialmente con cambios en los sistemas constructivos-, pero también medidas que implica una extensión de la ciudad "hasta los campos de Belém, o incluso a una distancia mayor, para recibir a toda la población que quedará sin hogar por la reducción del número de viviendas". El dónde reconstruir la plantea en relación a la ubicación del nuevo Palacio Real. Como señala Rossa "Todo lo que se había pensado para la capital joanina tenía como vórtice un nuevo complejo palatino, de hecho, en la continuidad del arquetipo instalado en Terreiro do Paço, en la transición entre la Edad Media y la Edad Moderna" (Rossa 2004).

Como señala Maia (op.cit) si para la construcción del Palacio Real se opta por Belém, "entre Alcântara y Pedrouços", se puede abandonar la ciudad destruida en manos de la iniciativa privada y construir una nueva ciudad "ex novo". Si se opta por la zona entre San João dos Bemcasados y el convento de la Estrela, zona de Ajuda, dentro de los límites de la inconclusa muralla de João IV, una zona alta y bien comunicada, se podrá "demoler todo el centro de la ciudad" utilizando los escombros para "aplanar" el área y reconstruirla según los criterios arriba señalados. Ésta será, finalmente, la opción escogida creando un balance entre la Lisboa oriental y la Lisboa occidental, división derivada de la ascensión a Patriarcado ${ }^{29}$ de la ciudad en 1716. Para ello se levantará en Ajuda un palacio provisional de madera para edificarlo posteriormente ${ }^{30}$.

29 Después de la creación de la Capilla Real en 1709, su elevación a Colegiata y de haber sido elevada a iglesia metropolitana y a basílica patriarcal, dedicada a Nuestra Señora de la Asunción, el 7 de noviembre de 1716, la ciudad de Lisboa y la diócesis se divide en dos partes: el Patriarcado de Lisboa Oeste con sede a la capilla real, con el título de Santa Iglesia Patriarcal, y la archidiócesis de Lisboa Oriental, con sede a la antigua Catedral de Lisboa. 30 Este palacio está inacabado, tanto por el hecho de que Maria I plantea un "regreso" al Paço da Ribeira, cuanto que la familia real huyó al Brasil en 1808 a raíz de la entrada de las tropas de Napoleón. 


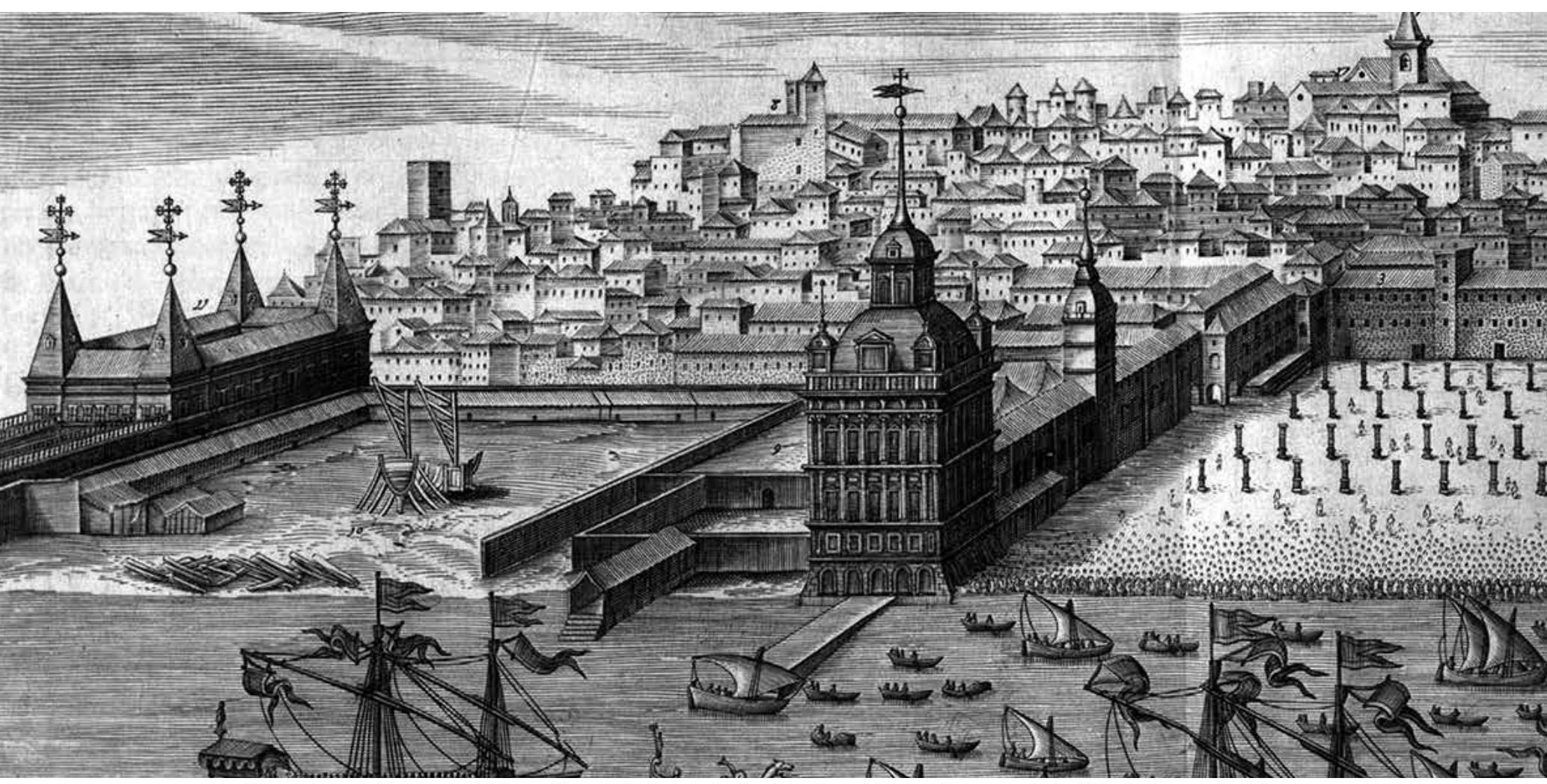

Desembarcación de su M. [se refiere a Felipe II de Portugal] en Lisboa (Fragmento) . Dibujado por Domingo Vleira y "cortada" por loan Schorquens (1622). La comparación estilística entre el torreón de Terzi y el Palacio de los Corte Real (a la derecha) muestra claramente la simplicidad de estilo de la arquitectura portuguesa, frente al manierismo de corte herreriano de la corte de los Felipes. Ref. Lavanha 1622

El puerto- ribeira

Es la propia idea del "puerto de Lisboa" que emerge. Antes, el burgo comunicaba con el mar por una miríada de muelles, especializados en los géneros que traficaban o en su origen- o Cais do Tojo, o de Pedra, o de Santarém, el del Furadouro, para las carreras Flandes y del Mediterrâneo, o Cais do Sodre, o do Carvão, o da Madeira ..., además de los de cada institución o palacio privado sobre el río. Un visón general surge apenas en el siglo XVIII, con el proyecto de Carlos Mardel (1742-1745), de unir la Aduana con Belém por un único muelle; que solo se torna realidad siglo y medio después, con los terraplenes y dársenas construidos por el ingeniero belga Pierre Hersant a partir de 1865 (Moreira 2004)

Lo que se hace evidente en el discurso de Maia es que la nueva ciudad no es compatible con la antigua, heredera de trazados medievales, con un decoro urbano alejado de los estándares de las capitales barrocas de la época, todo ello a pesar de las distintas actuaciones y programas de reforma que hemos analizado. El rechazo de Belém, podría derivarse, desde nuestro punto de vista, de la enormidad de la obra conducente a modernizar el puerto de la ciudad debido a la obsolescencia de las infraestructuras portuarias desarrolladas desde Manuel I. El aumento del tráfico marítimo unido al aumento de tonelaje y calado de los barcos del siglo XVIII precisaban de una mejora cuantitativa y cualitativa del puerto. Para ello era preciso ganar terreno al río buscando aguas más profundas, dar continuidad a las instalaciones portuarias superando el escollo de la Rocha do Conde de Óbidos y el delta del río de Alcântara y crear nuevas infraestructuras portuarias en consonancia con las nuevas necesidades marítimas. 
En la primera década del siglo XVIII los ingenieros militares habían realizado el levantamiento de los mapas topográficos de la región de Lisboa hasta Mafra, donde João V iniciara las obras de un palacio real en 1712. Como hemos mencionado, en 1719 el rey encarga a Juvarra el proyecto del nuevo complejo palatino en la zona de la Lapa que finalmente será desestimado. Poco después, en 1726, el Rey adquirirá el Palacio de Belem. Si en el reinado de Manuel I y posteriores, se vislumbraban claramente distintos centros de residencia real (Alcáçova, Rossio, Ribeira), siendo la Ribeira la conjunción entre el centro político-administrativo y el centro comercial, la búsqueda de un nuevo centro palatino (Mafra, Lapa, Belém) por parte de João V, confirman la idea de Rossa acerca de una especie de mapa mental del rey tendente a separar su residencia y corte de las actividades cotidianas del comercio e incluso de la gobernación del reino.

La existencia del palacio de Belém y las necesidades de crecimiento del puerto, parecen conjugarse en unos primeros estudios topográficos de la "marinha" de Lisboa desde Algés al convento do Grilo datados en 1727, atribuidos a la colaboración entre el ingeniero real Maia y al arquitecto del Senado de la Câmara de Lisboa, Custodio Vieira. Según Vieira da Silva, del orginal o de una copia se sirvió

"el ingeniero Carlos Mardel para un proyecto de obras a realizar en la margen sur de la ciudad, edificios, muelles, dársenas y astilleros, desde el sitio de la actual Praça de Afonso de Albuquerque hasta la Praça do Comércio, para mejorar el puerto de Lisboa y su desarrollo comercial. Esta copia es en papel continuo, a la misma escala que el original, no datado ${ }^{31}$ y lleva la firma de Carlos Mardel" (Vieira, 1950:18)

La descripción más precisa del proyecto nos la ofrece Loureiro (1904). El proyecto de Mardel consistía en un muelle continuo que partía aguas arriba de la aduana, seguía en línea recta hasta Ribeira das Naus, dejando dos grandes muelles, con escaleras, uno frente a la aduana y Jardim do Tabaco, otro frente del Paço Real. Continuaba hasta Santos, con una avenida arborizada, con nuevas viviendas y creando una amplia plaza con una iglesia parroquial y con una fuente monumental en el centro. Antes de llegar a esa nueva plaza, había un muelle destinado a las embarcaciones fluviales. En medio, este terraplén tendría un muelle sobre el río. El muelle continúa en línea recta acompañado por la avenida arbolada y una franja lateral de terreno para edificaciones. Tras superar del peñón del conde de Óbidos, un poco más abajo, en el lado Sur, un canal dejaba el nuevo arsenal naval separado de tierra. Hacia el norte, en la desembocadura del río de Alcântara, se conserva la laguna en la que está el 31 Sobre la datación de este trabajo existen diversas opiniones. Como señala Martins-Barata (2009) para Júlio de Castilho (Castilho 1893:95-96) o Loureiro (1904) el comitente de este proyecto fue el Marqués de Pombal en el reinado de José I. Por su parte Raquel Henriques da Silva el comitente habría sido al Rey D.João V. (Raquel Henriques 1997: 431). Walter Rossa también considera a D. João V como responsable del encargo de este plan urbanístico elaborado por Carlos Mardel, y lo data en 1733 (Rossa, 2004: 34). Por su parte Caetano (2004) lo data circa 1742, es decir en el reinado de João V. Como hemos visto Moreira data el proyecto entre 1742-1745 (Moreira 2004.), mientras que Costa, ante la dificultad lo data a mediados del siglo XVIII (Costa 2007) 

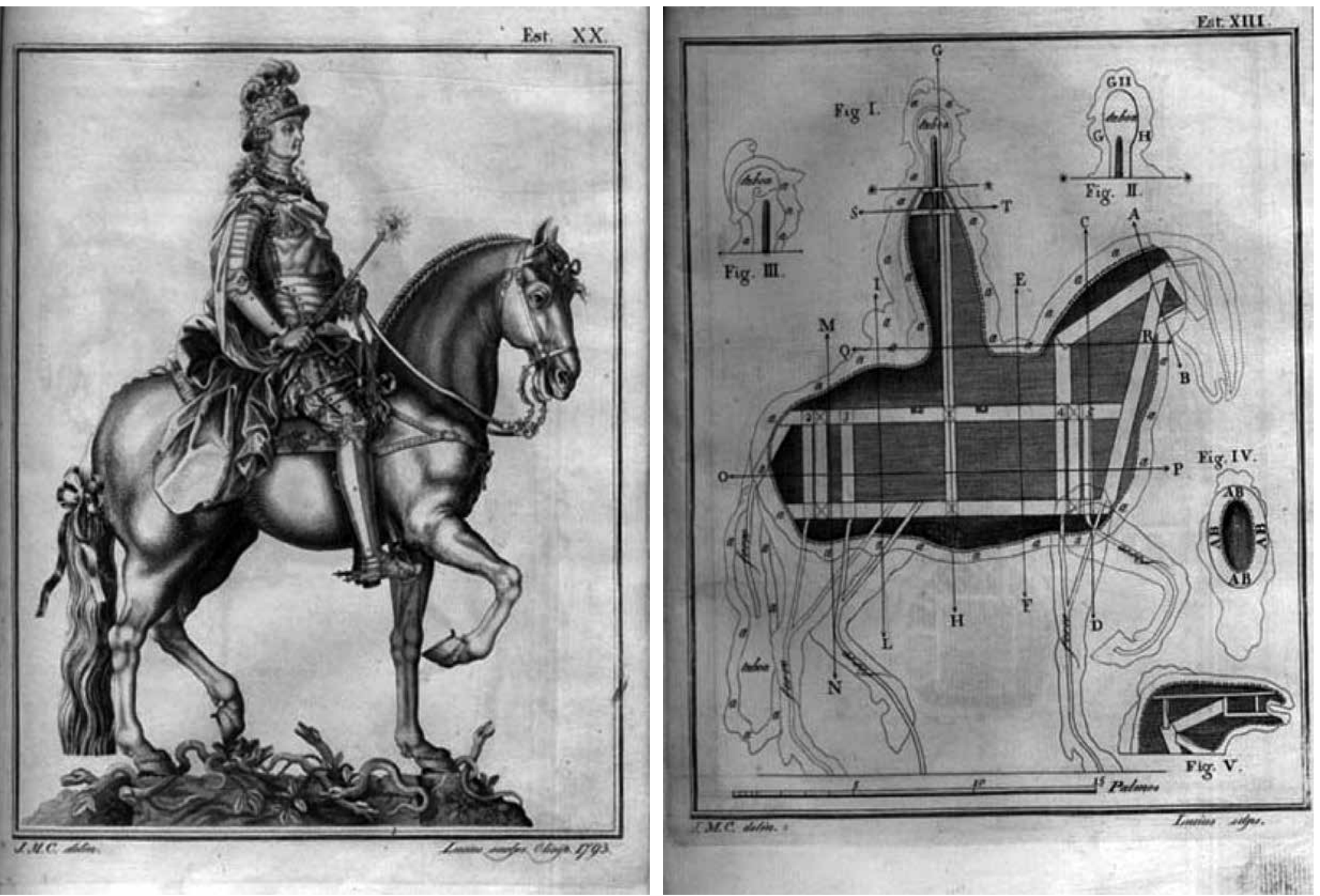

Estudios de Joaquín Machado de Castro (1810) para la realización de la estatua ecuestre de José I.

Cais do Sodré del ferrocarril de Cascais (1895), salvando el macizo de la Rocha do Conde de Óbidos. En otra escala muy distinta, se realizan operaciones de terraplenado en la parte oriental, condicionadas por el trazado de la vía férrea del Este (1856). La ampliación de la línea de costa mediante estos terraplenes condicionará el crecimiento lineal del puerto de Lisboa y su extensión hacia el margen izquierdo del Tajo, con instalaciones en 11 municipios distintos: Oeiras, Lisboa, Loures, Vila Franca de Xira, Benavente, Alcochete, Montijo, Moita, Barreiro, Seixal e Almada.

Siguiendo el argumento de Rossa arriba señalado, el proceso de reconstrucción de la ciudad implica que

"el centro de la ciudad sería ocupado por el Estado, dos décadas después figurado simbólicamente en la estatua ecuestre del monarca cuya morada se convirtió en una referencia periférica. Así, de modo algo reductor, podemos decir que el plano de 1755-1758 para la Baixa-Chiado es, también, para Portugal el símbolo del tránsito de un régimen (simplemente) absolutista para el de un despotismo iluminado o ilustrado (castigo, a pesar de todo, ..)" (Rossa 2004).

Esta "representación simbólica" del Rey mediante un artefacto escultórico, la podemos remontar al primer tercio del siglo $\mathrm{XV}$, uno de cuyos primeros ejemplos sería el dedicado a Alfonso $V$ de Aragón en Nápoles que analizamos en la primera parte de este 

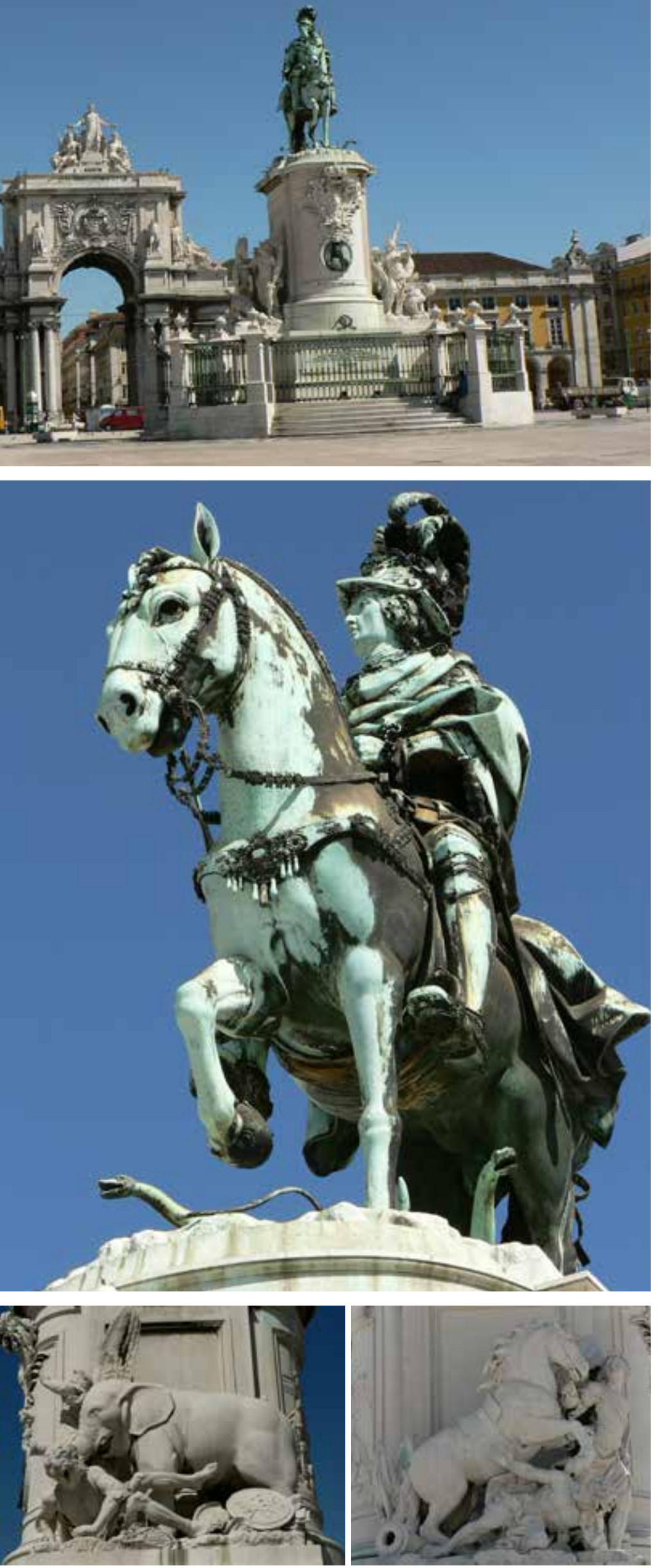

trabajo (Remesar 2021). Estas representaciones se sitúan, en su mayoría, en la "plaza", con su culminación en las denominadas "plazas reales" siguiendo el ejemplo de las francesas a partir del siglo XVII, cuando la residencia-palacio del Rey, se deslocaliza de la ciudad y de su centro, para ubicarse en las afueras, y cuyo mayor ejemplo seri el complejo palaciego de Versailles. Las obras que representan al rey, príncipe, soberano, se ejecutan "ante mortem", es decir que es el propio soberano quien decide "ubicar su figura" en el espacio público, aprobando las propuestas de los artistas. En este sentido es importante resaltar que este tipo de monumentos debería encajarse en la categrría de "monumentos advocativos" (Remesar 2011). Con estos monumentos, el soberano hace explícita su tutela, protección o patrocinio sobre sus súbditos. Su efigie nos recuerda su "poder" sobre nuestras vidas, al mismo tiempo que, de modo similar al papel que cumplen las efigies de santos en las puertas de entrada de la ciudad o de las capillas presentes en las calles, su efigie nos indica que estamos bajo su protección. La demostración del "poder" se manifiesta, sobre todo en las plazas reales, por el diseño mismo del espacio. La efigie ocupa el "centro" y es a partir de este- "centro-efigie del soberano"- que se articula el diseño del conjunto de la plaza, bajo la atenta mirada del Marqués de Pombal.

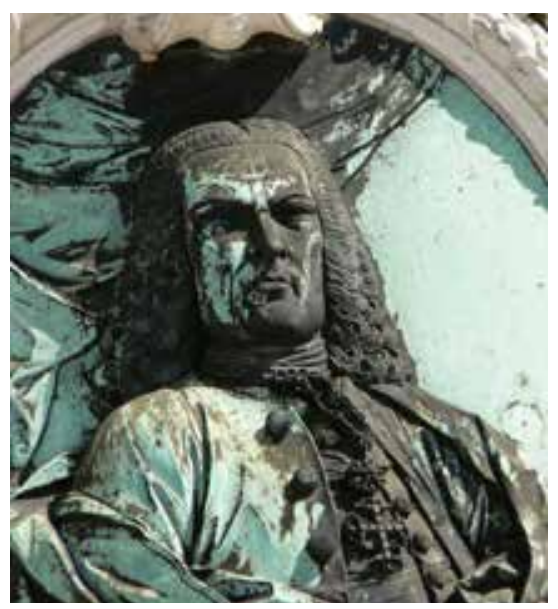




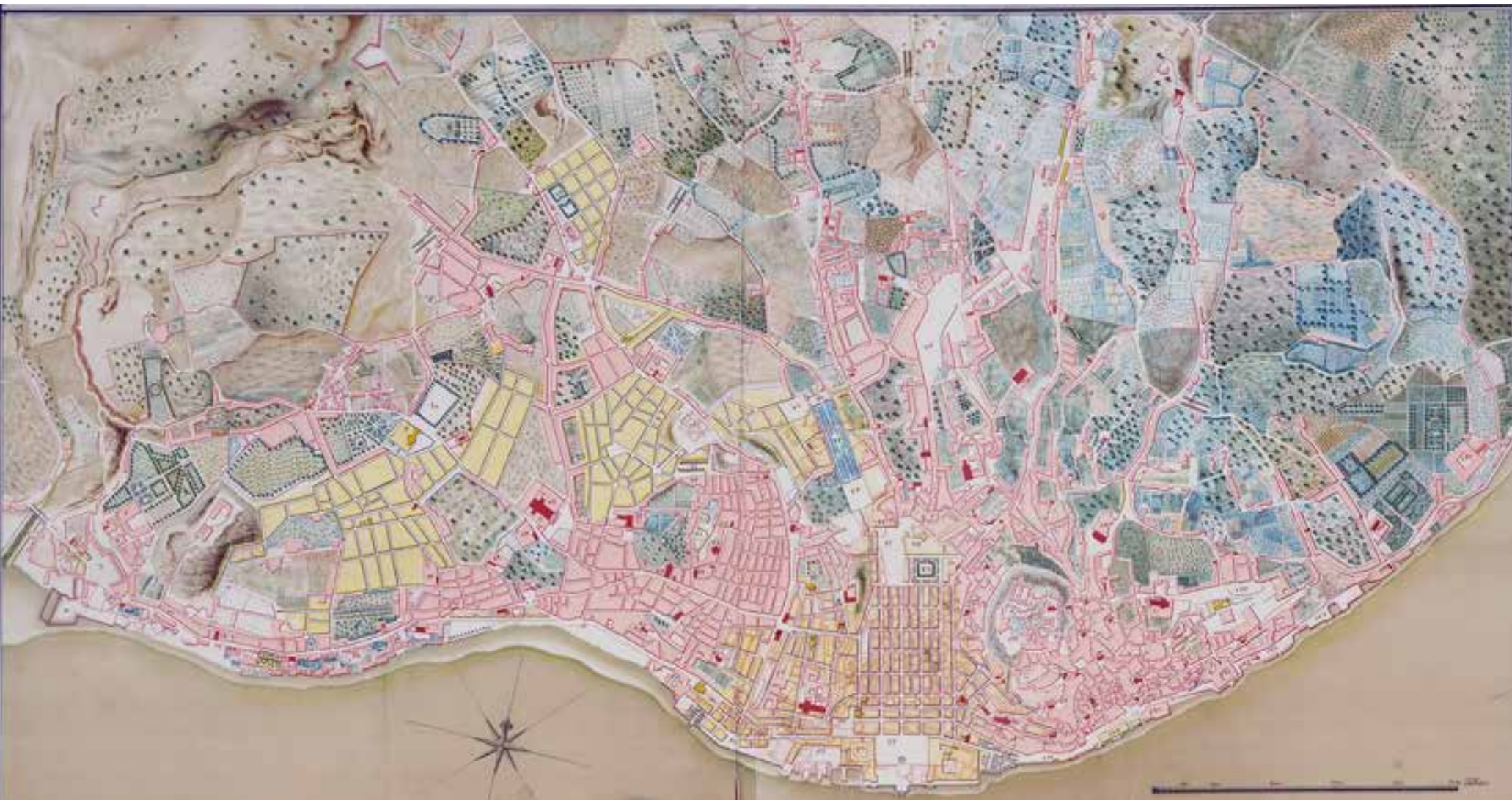

Planta Topograhica da Cidade de Lisboa. Según Vieira (1950) debió pertenecer al 3er cuarto del siglo XVIII, o anterior a 1780, ya que la Iglesia de la Estrella no está representada en él. El proyecto de reconstrucción de la Baixa, que modifica sustancialmente las rutas, es claramente visible.

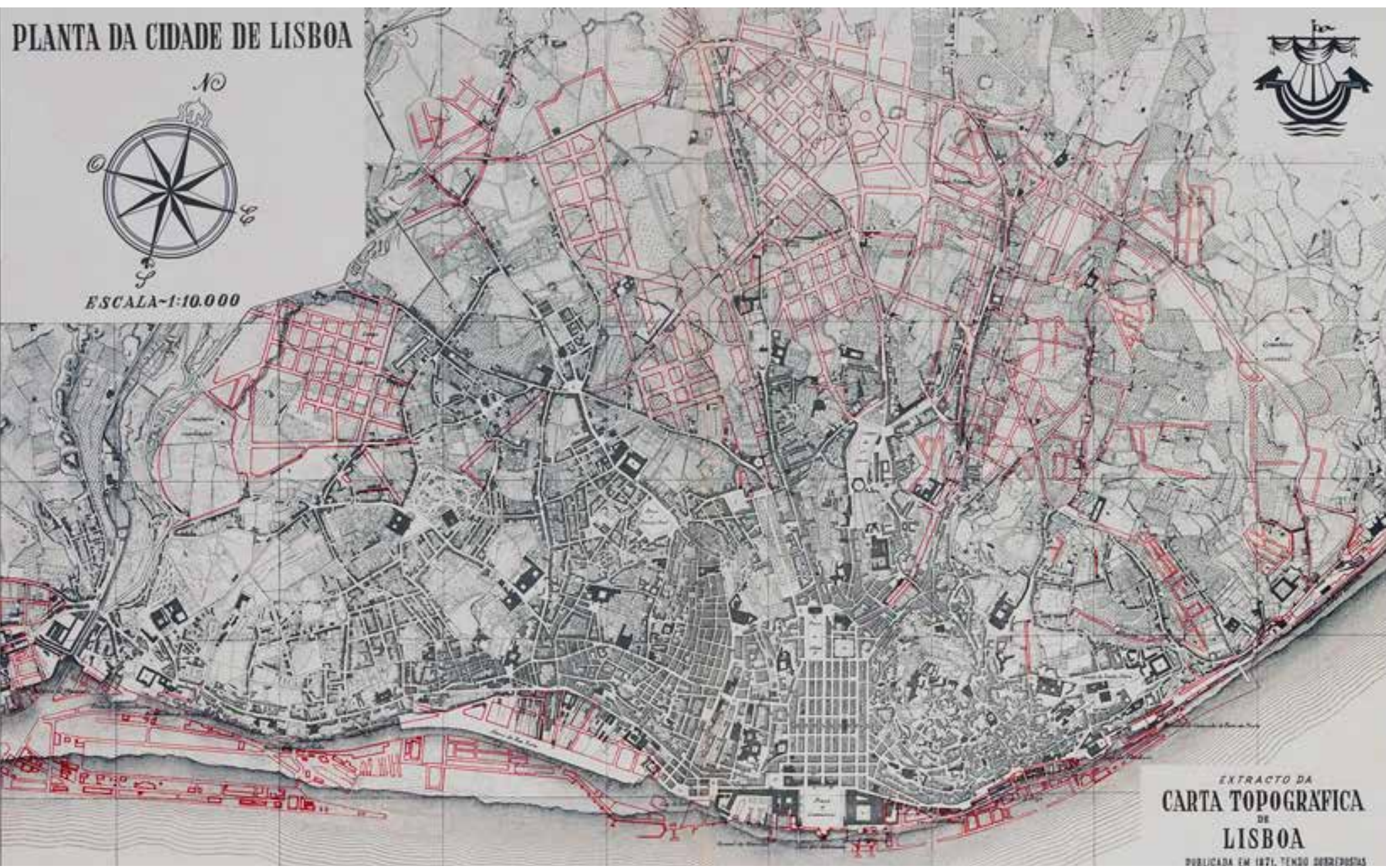

Planta de Lisboa 1871, en rojo las alteraciones introducidadas hasta 1911, que muestran [1] la realización del terraplenado y la construcción del puerto y [2] la tendencia de crecimiento de la ciudad hacia el Norte a raíz del proyecto de Avenidas Novas de Ressano García. Ref. Vieria da Silva 1950 


\section{Conclusiones}

Mientras el modelo romano organiza la reconversión de la ciudad en relación al predominio de un centro físico-espiritual, la basílica de San Pedro, desplegándose los principios renacentistas mediante el patronazgo de los Papas a figuras relevantes de este movimiento - desde Alberti a Miguel Ángel-. La reestructuración de la ciudad medieval, así como el ensanche de Roma, genera profundas trasformaciones del viario con normas y reglas claras dominadas por la proporción y el orden, especialmente en la etapa manierista. Roma cuenta con la ventaja de la gran extensión del antiguo recinto amurallado y de la pervivencia de algunas infraestructuras, como los acueductos, que facilitarán la implementar los proyectos de cambio. Serán las 7 iglesias las que conformarán una especie de "centro-descentrado" que pivota sobre aspectos espirituales y en los que se operan acciones de decoro urbano, como fue la implantación y la resignificación de los obeliscos de la antigua Roma.

En Lisboa, la situación es muy distinta. En primer lugar, porqué el crecimiento de la ciudad está condicionado por la existencia de un exiguo recinto amurallado. Por ello, el crecimiento será similar al que vimos en el caso de Barcelona (Remesar 2021): creación de arrabales y mejora del trazado de las calles interiores a los recintos amurallados. A partir de la pragmática de los modos de hacer ciudad del final de la Edad Media y mediante un conjunto de disposiciones regias se transita de la construcción en madera, a la construcción con piedra y cal. Se evoluciona del trazado de la ciudad musulmana a un sistema de organización espacial basado en el esquema de la "calle directa- travesío" que produce modulaciones parcelarias con series numéricas de base proporcional, que culminará con el esquema de la manzana, cuando finalmente, los nuevos barrios se construyen más allá del recinto de murallas (Bairro Alto). Las manzanas presentaran unos solares cuadrangulares que sustituyen los antiguos solares medievales, estrechos y alargados, con una construcción de edificios de dos plantas en mampostería de piedra y cal, con jambas rectas de piedra de calcárea (pedra de lioz), lo que introduce una 'arquitectura de programa' (Carita 1999) basada en una estética unitaria que determinaría buena parte de la arquitectura moderna en Portugal. Las normas preconizan aspectos de decoro urbano como la alineación de los solares en relación a la calle, el trazado a cordel, las fachadas a plomada, limitación de anchura balcones para no ocupar el espacio común de la calle.

Lo más relevante en Lisboa es el paulatino descentramiento del centro original, la Alcáçova- catedral. Emergen dos nuevos centros: el Rossio y la Ribera. El primero, un espacio común, se convertirá en un centro residencial - a partir del Palacio dos Estaus, asistencial-con el Hospital Real de Todos-os-Santos- y de mercado. En este sentido destacar la importancia de la implantación de elementos primarios de urbanización (Rossi 1968). El segundo caso presenta aspectos más interesantes. La Ribera se 
reorganiza como puerto de las conquistas, a partir [1] de la necesidad de ampliar y mejorar los elementos primarios de la actividad comercial (muelles, almacenes, aduana, granero, astilleros, control de aranceles...) y [2] del traslado de la corte desde la Alcáçova a la Ribera con la construcción de los Paços da Ribeira. Los grandes edificios o piezas urbanas, tienen una doble capacidad crítica, catalítica,

"de servir por un lado como hito topográfico dentro de la deslocalización de la megalópolis y, por otro, de encarnar dentro de su matriz programática una urbanidad que, por lo demás, está en gran medida ausente del espacio infinito de la región urbanizada. Nada de esto debe impedir la adopción de respuestas matizadas, más orientadas a la renovación del tejido urbano tradicional existente, ni tampoco la aplicación de intervenciones reparadoras pensadas y ejecutadas en términos exclusivamente paisajísticos. (Frampton 1980:76).

Este movimiento corresponde a los procesos de centralización política y mayor poder de los reyes en la creación de los Estados Nacionales, correlato del inicio del capitalismo comercial. Uno de los aprendizajes que podemos obtener del caso de Lisboa, es que estos "nuevos centros" continúan estando presentes en el imaginario urbano-en los mapas mentales y en el uso de la toponimia- de los lisboetas .... y de los turistas. Todo ello a pesar del terremoto de 1755 y de la reconstrucción de la ciudad.

A medida que el modelo político se orienta hacia el absolutismo, obtenemos una nueva lección de Lisboa: la segregación entre "centro" vinculado a la figura del rey (caso de los Paços da Ribeira) y "centro urbano". Hemos visto como los reyes portugueses, inician una especie de ciclo de "búsqueda del centro" creando nuevas sedes para su residencia y huyendo del "centro" creado por Manuel I en la Ribeira. Una búsqueda que nos habla de la disociación de la idea de centro vinculada con la figura del rey-corte de la idea de centro propiamente urbano. Una disociación que se concretará tras el terremoto de 1755: el rey - José I- ocupará el centro en efigie (estatua, monumento) no en persona, una especie de estar siempre presente sin estar personalmente aquí, una relación omnipresente y vicaria con los súbditos, inaugurada ya en el Renacimiento y desarrollada en el modelo francés de plazas reales. 


\section{Referencias}

ALBERTI, Leon Battista. 1433. Descriptio urbis Romae. 1582nd ed. Madrid: Biblioteca Nacional.

ALBERTI, Leon Battista. 1452. De Re Aedificatoria. Los diez libros de la Arquitectura. 1991st, trad. Javier Fresnillo Nuñez ed. Madrid: Akal.

ÁLVARO-ZAMORA, MA I, AND JAVIER IBÁÑEZ-FERNÁNDEZ. 2012. 'Hacia Un Corpus de Arquitectura Jesuítica. Bases Actuales y Líneas de Trabajo Futuro'. In Álvaro Zamora, Ma I., Ibáñez Fernández, J. y Criado Mainar, J. (Coords.), La Arquitectura Jesuítica, Actas Del Simposio Internacional., 5-37. Zaragoza: Institución "Fernando el Católico" (CSIC), https://ifc.dpz.es/recursos/publicaciones/31/96/ ebook.pdf

ANTUNeS, AleXANDRA DE CARVALHO. 2017. Cais Real de Belém e Cais Da Pedra No Terreiro Do Paço. Planos de D. João V Para a Marinha de Lisboa. 20 aumentada 2019. Lisboa: MAZU PRESS.

ARGAN, GIULIO CARLO. 1961. Proyecto y Destino. Caracas: Publicaciones de la Universidad Central de Venezuela.

ARGAN, GIULIO CARLO. 1998. História da Arte como História da Cidade. Sao Paulo: Martins Fontes Editora.

ARGAN, Giulio Carlo. 2004. 'Humanity, Art and History'. In HOLLINGSWOTH, Mary. Art in World History, 2016th ed., 542. Oxford- New York: Routledge.

BENÉVOLO, LEONARDO. 1975. Diseño de la Ciudad. Edición castellana 1977. Vol. 3. Barcelona: Gustavo Gili.

BLUMBERG, NAOMI, AND IDA YALZADEH. 2019. 'City Beautiful Movement'. In Encyclopedia Britannica. https:// www.britannica.com/topic/City-Beautiful-movement

BOHL, CH.C - LEJEUNE, J-F (ed). 2009. Sitte, Hegemann and the Metropolis: Modern Civic Art and International Exchanges. New York: Routledge. https://ja.cat/FgF6I

BORDINO, Giovani Francesco. 1588. De Rebus Praeclare Gestis a Sixto V. BNF Gallica.fr. París. ark:/12148/ btv1b84467829

BORGES-COELHO, António. 2006. Ruas e Gentes na Lisboa Quinhentista. Lisboa: Caminho.

BURKE, Peter. 1986. El Renacimiento Italiano. Cultura y Sociedad En Italia. 20 Ed. digital 2015. Madrid: Alianza Editorial.

CAETANO, Carlos. 2004. A Ribeira de Lisboa. Na Época Da Expansão Portuguesa (Séculos XV a XVIII). Lisboa: Pandora Ediçôes.

CAPEL, Horacio. 2002. La Morfología de Las Ciudades. Tomo I. Sociedad, Cultura y Paisaje Urbano. Barcelona: Ediciones de Serbal.

CAPEL, Horacio. 2003. 'A Modo de Introducción: Los Problemas de Las Ciudades. Urbs, Civitas y Polis'. In In Capel, Horacio (Coord) Ciudades, Arquitectura y Espacio Urbano, 9-24. Alicante: Cajamar.

CARITA, Helder. 1994. Bairro Alto Tipologias e Modos Arquitectónicos. Lisboa: Camara Municipal de Lisboa.

CARITA, Helder. 1999. Lisboa Manuelina e a Formação de Modelos Urbanísticos Da Época Moderna. Lisboa: Livros Horizonte.

CARITA, Helder. 2015. 'Lisboa Manuelina e a Formação Da Provedoria de Obras Reais'. Rossio. Estudos de Lisboa, June 2015. http://www.cm-lisboa.pt/fileadmin/DOCS/Publicacoes/publicacoes-digitais/Revista Rossio/rossio estudos de lisboa $n$ 5.pdf

CASTILHO, Julio de. 1879. Lisboa Antiga (Primeira Parte. O Bairro Alto). Lisboa: Livraria de A.M. Pereira, Editor. https://archive.org/details/gri 33125000417192

CASTILHO, Julio de. 1890. Lisboa Antiga (Bairros Orientais). 1937th ed. Vol. X. Lisboa: S. Industrias da C,M,L,. https://purl.pt/30262/4/hg-15990-v/hg-15990-v item4/hg-15990-v PDF/hg-15990-v PDF 24-C-R0150/hg15990-v 0000 capa-capa t24-C-R0150.pdf

CASTILHO, Julio de. 1893. A Ribeira de Lisboa : Descripção Histórica Da Margem Do Tejo Desde a Madre-de-Deus Até Santos-o-Velho. Lisboa: Imprensa Nacional. https://archive.org/details/ribeiradelisboad00cast

CERTEAU, Michel de. 1990. La Invención de Lo Cotidiano. I. Artes de Hacer. 2000th ed. México D.F.: Universidad Iberoamericana.

CERTEAU, Michel de; GIARD, Luc; MAYOI, Pierre. 1999. La Invención de Lo Cotidiano. 2. Habitar, Cocinar. México: Universidad Iberoamericana.

CHOAY, Françoise. 1965. L'urbanisme: Utopies et Realités. Paris: Seuil.

CHOAY, Françoise. 1980. La Règle et le Modèle. Sur la théorie de l'architecture et de l'urbanisme. Paris: Seuil.

CHOAY, Françoise.. 1988. 'Art Urbain'. In MERLIN, Pierre - CHOAY, Françoise.Dictionnaire de I'Urbanisme et de l'aménagement, 2005th ed., 83-84. París: PUF. 
CORREIA, José Eduardo Horta. 1986. 'A Arquitectura: Maneirismo e "Estilo Chão"'. In AA.VV. História Da Arte Em Portugal. Vol. VII. Lisboa: Publicações Alfa.

COSTA, João Pedro. 2007. 'La Ribera Entre Proyectos. Formación y Transformación Del Territorio Portuario, a Partir Del Caso De Lisboa'. Tesis Doctoral, Barcelona: Universitat Politècnica de Catalunya. http://tdx.cat/hand$\underline{\text { le/10803/6960 }}$

DOMÈNCH I MONTANER, Lluís, and PUIG I CADAFALCH, Josep (DIR). 1886. Historia General Del Arte : Escrita e llustrada En Vista de Los Monumentos y de La Mejores Obras Publicadas Hasta El Día / Bajo La Dirección de D. Luis Domènech (y D. José Puig y Cadafalch). Vol. II Arquitectura. El Renacimiento. 8 vols. Barcelona: Montaner y Simón. https://ddd.uab.cat/pub/llibres/1886-1897/56958/hisgenart a1901t2r16.pdf

FONTANA, Doménico. 1589. Della Trasportatione Dell'obelisco Vaticano et Delle Fabriche Di Nostro Signore Papa Sisto V. Roma. https://dadun.unav.edu/handle/10171/6257

FRAMPTON, Kenneth. 1980. Historia Crítica de la Arquitectura Moderna (1980). 1993 sexta ampliada. Barcelona: Gustavo Gili.

FRANÇA, José Augusto. 1987. Lisboa Pombalina e o llusminismo. Lisboa: Bertrand Editora.

FRANÇA, José Augusto 1997. Lisboa: Urbanismo e Arquitectura. 3o. Lisboa: Livros Horizonte.

FRANÇA, José Augusto. 2008. Lisboa. História Física e Moral. Lisboa: Livros Horizonte.

FRANCINI, Girolamo. 1595. Le Cose Maravigliose Dell'alma Citta Di Roma, Col Movimento Delle Guglie et Gli Aquedotti. Le Ampe \& Commode Strade, Fatte à Beneficio Publico Dal Santissimo Sisto V. Roma. https://onb.digital/ result/108F8E0E

GIEDION, S. 1941. Espaço, tempo e arquitetura. O desenvolvimento de uma Nova Tradiçao Ed. 2004 . Sao Paulo: Martins Fontes Editora.

GIOVANNONI, Gustavo. 1931. L'Úrbanisme face aux villes anciennes. 1998th ed. Paris: Éditions du Seueil.

GIOVANNONI, Gustavo. 1935. Saggi Sulla Architettura Del Rinascimento. 20. Milano: S.A. Fratelli Treves Editori. https://archive.org/details/giovannoni-saggi-architettura-del-rinascimento

GIOVANNONI, Gustavo. 1945. Architetture di pensiero e pensieri sull'Architettura. 1945th ed. Roma: Apollon. https://archive.org/details/giovannoni-architetture-di-pensiero

GÓIS, Damião de. 1558. Chronica Do Sereníssimo Senhor Rei Manoel. 1749th ed. Lisboa: Officina de Miguel Manescal da Costa. https://www.scribd.com/document/117299970/Cronica-de-D-Manuel-por-Damiao-de-Gois

HARVEY, David. 1973. Urbanismo y Desigualdad Social. 1977th ed. México: S. XXI.

HAUSER, Arnold. 1951. The Social History of Art. Renaissance, Mannerism and Baroque (Vol II). 1992nd ed. London: Routledge \& Kegan Paul.

HEGEMANN, W; PEETS,E. 1922. The American Vitruvius: An Architects' Handbook of Civic Art. 1988th ed. New York: Princenton Academic Press. https://archive.org/details/americanvitruviu00hege/page/n6

HENRIQUES, P.aulo (2004). Lisboa antes do terramato. Grande vista da cidade entre 1700 \& 1725. Gótica- Chandeigne.

HENRIQUES DA SILVA, Raquel. 1997. 'Lisboa Romântica, Urbanismo e Arquitectura, 1777- 1874'. Lisboa: Universidade Nova de Lisboa.

HIDALGO, David. 2014. 'Leonardo Da Vinci Arquitectura y Urbanismo. El Concepto de Ciudad Ideal'. Tesis doctoral, Alacant: Universitat d'Alacant. http://rua.ua.es/dspace/handle/10045/42245

HOLANDA, Francisco de. 1540. Os Desenhos Das Antigualhas Que Vio Francisco d'Ollanda Pintor Portugués (15391540). 1940. Notas a cargo de Eliseo Tormo.Reproducción facsimil del codice de Francisco d'Ollanda que se custodia en la Biblioteca del Escorial. Madrid: Ministerio de Asuntos Exteriores. https://acortar.link/8Kfl81

HOLANDA, Francisco de.1571. Da Fabrica Que Falece a Cidade de Lisboa. 1879 de Joaquim de Vasconcelos. Porto: Imprensa Portuguesa. https://ia600206.us.archive.org/14/items/DELTA53898 6FA/BSG DELTA53898 6FA.pdf

KUBLER, George. 1972. Portuguese Plain Architecture: Between Spices and Diamonds 1521- 1706. Middletown, Conn.: Wesleyan University Press.

LAVEDAN, Pierre. 1959. Histoire de l'urbanisme à Paris. 1975th ed. París: Association pour la publication d'une Histoire de Paris.

LAVANHA, J. B. (1622). Viagem da Catholica Real Magestade del Rey D.Filipe II. N.S. ao Reyno de Portugal. Thomas Iunti Impressor del Rei NS. https://bibliotecadigital.rah.es/es/consulta/registro.do?id=6216

LEAL, JOANA DA CUNHA. 2005. 'Arquitectura Privada, Política e Factos Urbanos Em Lisboa: Da Cidade Pombalina à Cidade Liberal.' Ph.D. Diss., Lisboa: Universidade Nova de Lisboa. 
LEAL, JOANA DA CUNHA. 2013. 'Plain, Pombaline and (Post)Modernism: On Some Pre and Post-Kublerian Narratives on Portuguese Architecture'. Cescontexto Debates 3: 7-17. http://www.ces.uc.pt/publicacoes/cescontexto/ index.php?id=8350

LOUREIRO, Alphonso Ferreira de. 1904. Os Portos Marítimos de Portugal e Ilhas Adjacentes. 3 vols. Lisboa: Imprensa Nacional. https://ia800501.us.archive.org/28/items/p2osportosmariti03lour/p2osportosmaritio3lour.pdf

MACHADO DE CASTRO, Joaquin. (1810). Descripção analítica da execução da estatua equestre do senhor rei fidelíssimo D. José I. (Biblioteca Nacional Digital). Impressam Régia. https://purl.pt/960

MAIA, Manuel da. 1775. 'Dissertação de Manuel Da Maia'. In José-Augusto França. Lisboa e o lluminismo., 1987th ed., 311-26. Venda Nova: Bertand Editora.

MARTINS-BARATA, Ana. 2009. 'A Ordenação Do Espaço Litoral de Lisboa, 1860-1940'. Scripta Nova. Revista Electrónica de Geografía y Ciencias Sociales XIII (296 (4)). http://www.ub.edu/geocrit/sn/sn-296/sn-296-4.htm

MOITA, Irisalva. 1983. Lisboa Quinhentista. A Imagem e a Vida Da Cidade. Câmara Municipal de Lisboa. Lisboa: Museu da Cidade.

MOITA, Irisalva. (dir). 1990. D. João Ve o Abastecimento de Água a Lisboa. Lisboa: Câmara Municipal de Lisboa.

MONCLÚS, F.J. 1995. 'Arte Urbano y Estudios Histórico-Urbanísticos. Tradiciones, Ciclos y Recuperaciones'. 3ZU: Revista d'arquitectura, no. 4. https://acortar.link/LN1TKz

MOREIRA, Rafael. 2004. 'O Cais Do Mundo'. In Caetano, Carlos. A Ribeira de Lisboa. Na Época Da Expansão Portuguesa (Séculos XV a XVIII). Lisboa: Pandora Ediçôes.

MORRIS, A.E.J. 1979. Historia de la Forma Urbana, desde sus orígenes hasta la Revolución Industrial. Edición castellana 2007. Barcelona: Gustavo Gili.

MÜNSTER, Sebastian, and François BELLEFOREST. 1550. La Cosmographie Universelle de Tout Le Monde :Second Volume Du Premier Tome. Contenant Les Autres Pays Des Gaules, Non Compris Sous La Couronne de France, Avec Plusieurs Autres Provinces. 1557 (Biblioteca Digital Hispanica). París: Chez Nicolas Chesneau. http://bdh-rd.bne.es/ viewer.vm?id=0000001426

MÜNZER, Jerónimo. 1924. 'Viaje Por España y Portugal En Los Años 1494 y 1495 (Trad. Julio Puyol)'. Boletin de La Real Academia de La Historia LXXXIV (Cuaderno I): 33-119. https://ia803107.us.archive.org/7/items/boletindelareala84madr/boletindelareala84madr.pdf

MURTEIRA, Helena. 1999. Lisboa, Da Restauração Às Luzes. Lisboa: Editorial Presença.

NEWMAN, Robert. 2013. Baroque and Rococo. Art and Architecture. New Jersey: Pearson Education, Inc.

OLIVEIRA, Catarina. 2012. 'Casa de Brás de Albuquerque (casa dos Bicos), fachada'. Website. Patrimonio Cultural. Direção-Geral do Património Cultural (Portugal). 2012. http://www.patrimoniocultural.gov.pt

OLIVEIRA SILVEIRA, Ana Cláudia. 2017. 'Alcântara: Um Moinho de Maré Medieval No Termo de Lisboa (Séculos XIII a XVIII)'. Cadernos Do Arquivo Municipal, December 2017.

PANOFSKY, Erwin. 1960. Renacimiento y Renacimientos En El Arte Occidental. 1975th ed. Madrid: Alianza Universidad.

PEVSNER, Nikolaus. 1945. An Outline of European Architecture. 1948th ed. London and Aylesbury: Penguin Books.

QUARONI, Ludovico. 1959. “'Una Città Eterna, Quattro Lezioni Da Ventisette Secoli En Urbanistica'. Urbanística. Rivista Dell'Istituto Nazionale Di Urbanistica, no. 27 (June): 6-82.

REMESAR, Antoni. 2011. 'O Carácter Simbólico Da Rua, Identidade e Apropiação'. In In BRANDÃO, P (ED) A Rua é Nossa... de Todos Nós! Lisboa: MUDE- Instituto Superior Técnico.

REMESAR, Antoni. 2016. 'New Urban Decorum? Aesthetics To and Fro'. In In GRALIŃSKA-TOBOREK;A-KAZIMIERSKA-JERZYK, W (ED) Aesthetic Energy of the City, 19-54. Lodz: Wydawnictwo Uniwersytetu Łódzkiego (Łódź University Press). https://ur.es1lib.org/book/11974459/92feb9

REMESAR, A., \& RÍOS, M. (2018). Barcelona s. XVIII, un paisatge en construcció. On the W@terfront [En Línia], 60(1), 9-77. http://raco.cat/index.php/Waterfront/article/view/331618/422323

REMESAR, Antoni. 2019. 'Del Arte Público al Post-Muralismo. Políticas de Decoro Urbano En Procesos de Regeneración Urbana (I)'. On the W@terfront. Public Art.Urban Design.Civic Participation.Urban Regeneration 61 (1): 3-65. https://doi.org/10.1344/waterfront2019.61.6.1

REMESAR, Antoni. 2020. 'From Drinking Fountains to Promenades. Water as Artistic Medium?' On the W@terfront. Public Art.Urban Design.Civic Participation.Urban Regeneration 62 (1): 3-84. https://doi.org/10.1344/waterfront2020.62.6.1

REMESAR, Antoni. 2021. "'Searching for the Center. First Part"'. On the W@terfront. Public Art.Urban Design.Civic Participation.Urban Regeneration 63 (8): 3-65. https://doi.org/10.1344/waterfront2021.63.8.01 
REMESAR, Antoni, and FERNANDO NUNES DA SILVA. 2019. 'Políticas Urbanas: Arte Pública na Regeneração Urbana'. In ANDRADE, P; ALMEIDA MARQUES, C; CUNHA BARROS, José da (Ed) Arte Pública e Cidadania, 20 (revista e aumentada), 73-115. Lisboa: Editora Caleidoscópio - Edição e Artes Gráficas, SA. http://doi.org/10.30618/978$\underline{989-658-589-1}$

RISEBERO, Bill. 1986. La Arquitectura y el Diseño Modernos. Una Historia Alternativa. Barcelona: Hermann Blume. RISEBERO, Bill. 1992. Fantastic Form. Architecture and Planning Today. London: The Herbert Press.

ROBINSON, Ch. Mulford. 1904. Modern Civic Art or The City Made Beautiful. New york- Iondon: G.P. Putnam's Sons. http://www.archive.org/details/civicartormodernOOrobirich

ROSSA, Walter. 2004. 'Do Plano de 1755-1758 Para a Baixa-Chiado'. Monumentos. Revista Semestral de Edificios e Monumentos, no. 21: 22-43.

ROSSA, Walter and Luisa TRINDADE. 2006. 'Questões e Antecedentes Da "Cidade Portuguesa": O Conhecimento Sobre o Urbanismo Medieval e a Sua Expressão Morfológica'. Murphy - Revista de História e Teoria Da Arquitectura e Do Urbanismo 1: 70-109.

ROSSI, Aldo. 1968. La Arquitectura de la Ciudad. Barcelona: Gustavo Gili.

SABATÉ, Joaquim. 1999. El Proyecto de La Calle Sin Nombre. Los Reglamentos Urbanos de La Edificación ParísBarcelona. Barcelona: Fundación Caja de Arquitectos.

SOLÀ-MORALES, Ignasi. 1995. 'Arquitectura débil'. In SOLÀ-MORALES, Ignasi. Diferencias. Topografía de la arquitectura contemporánea, 185. Barcelona: Gustavo Gili.

TAFURI, Manfredo. 1992. Sobre El Renacimiento. Principios, Ciudades, Arquitectura. 1995th ed. Madrid: Cátedra.

TAYLOR, R, WENWORTH, K.R, AND KOSTOF, SPIRO. 2016. Rome. An Urban History from Antiquity to the Present. Cambrige University Press.

TORRES, Claudio. 1995. 'Lisboa Muçulmana. Um Espaço Urbano e o Seu Terrtorio'. Trabalhos de Antropologia e Etnologia 35 (3): 427-34.

TORRES-BALBÁS, Leopoldo. 1954. 'La Edad Media'. In in AA.VV Resumen Histórico del Urbanismo en España, Edición 1987, 68-172. Madrid: Instituo de Estudios de la Administración Local.

TOSTÕES, A., \& ROSSA, W. (2009). Lisboa 1758. O Plano da Baixa. Câmara Municipal de Lisboa.

TRINDADE, Luísa. 2016. 'Uma Outra Representação Da Rua Nova Dos Mercadores, Em Lisboa: A Tábua Do “Martírio de S. Sebastião", de Gregório Lopes'. Medievalista [Em Linha], no. 20 (July). https://doi.org/10.4000/medievalista.1180.

VALE, A, AND L FERNANDES. 1997. 'Intervenção Arqueológica Na Praça de D. Pedro IV (Rossio) Em Lisboa'. In Atas Do 3.o Encontro Nacional de Arqueologia Urbana (Almada, 20 a 23 de Fevereiro de 1997), 109-21. Monografias Arqueologia. Almada: Câmara Municipal de Almada. Divisão de Museus.

VARELA, Paulo, and Rui LOBO. 2012. 'Arquitectura de Los Jesuitas En Portugal y En Las Regiones de Influencia Portuguesa'. In ÁLVARO ZAMORA, Ma I., IBÁÑEZ FERNÁNDEZ, J. y CRIADO MAINAR, J. (Coords.), La Arquitectura Jesuítica, Actas Del Simposio Internacional., 497-521. Zaragoza: Institución "Fernando el Católico" (CSIC),. https://ifc.dpz.es/ recursos/publicaciones/31/96/ ebook.pdf

VARNHAGEN, Francisco Adolfo de. 1842. Notícia Histórica e Descriptiva Do Mosteiro de Belém. Lisboa: Typographia da Sociedade Propagadora dos Conhecimentos Uteia. https://archive.org/details/noticiahistorica00varn

VASARI, Glorgo. 1550. Le Vite de Piu Eccellenti Pittori, Scultori e Architettori. 1568. Di nuouo dal medesimo riuiste et ampliate con i ritratti loro et con l'aggiunta delle vite de' viui, De' morti dall'anno 1550. insino al 1567. Vol. 1. Florencia: Eredi di Bernardo Giunta- impresor. http://bdh.bne.es

VERDUGO, J. 2017. 'La Reinterpretación Cristiana de Los Monumentos de La Antigüedad En La Roma de Sixto V (1585-1590)'. Archivo Español de Arqueología, no. 90: 53-76. https://doi.org/10.3989/aespa.090.017.003.

VIEIRA DA SILVA, Augusto. 1940. As Muralhas Da Ribeira de Lisboa. 1987th ed. Lisboa: Câmara Municipal de Lisboa.

VIEIRA DA SILVA, Augusto. 1948. A Cerca Fernandina de Lisboa. 1987th ed. Vol. vol I. Lisboa: Câmara Municipal de Lisboa.

VIEIRA DA SILVA, Augusto. 1950. Plantas Topográficas de Lisboa. Lisboa: Câmara Municipal. https://purl.pt/27804 WILSON, William H. 1989. The City Beautiful Movement. Baltimore and London: The Johns Hopkins Univerity Press. WIRTH, Louis. 1938. 'Urbanism as a Way of Life'. The American Journal of Sociology, 1938. http://www.jstor.org/ stable/2768119

ZEVI, Bruno. 2006. Saper Vedere La Città. Ferrara Di Biagio Rossetti, «la Prima Città Moderna Europea». Turin: Biblioteca Einaud. 
(C) Antoni Remesar. CR POLIS- CRIT Research Group. Universitat de Barcelona aremesar@ub.edu

Orcid: https://orcid.org/0000-0002-1145-6279; Scopus Author ID: 55323348400; Researcher ID: J-9745-2016

Professor at the University of Bacelona. Director of CR POLIS. Coordinator of the Master in Urban Design: Art, City, Society. Member of the consolidated research group CRIT (Creation Innovation and Urban Transformation) of the University of Barcelona. He has coordinated the PhD program Public Space and Urban Regeneration of the University of Barcelona (1999-2017) and has been Vice Dean of Research and Postgraduate (2006-2016). He has supervided 30 doctoral thesis and has been PI of 10 competitively funded research projects on Public Art, Urban Design, Urban Reneration.

\section{Reconocimientos}

Ester trabajo forma parte del proyecto de investigación HAR2017-88672-R financiado por el Ministerio de Ciencia e Innovación de España y Fondos Sociales Europeos 